\title{
PRODUÇÃO DE MUDAS CÍTRICAS EM VIVEIRO: USO DE SUBSTRATO ALTERNATIVO E INOCULAÇÃO COM Xylella fastidiosa
}

\section{RONALDO ALBERTO DUENHAS CABRERA}

\begin{abstract}
Dissertação apresentada à Escola Superior de Agricultura "Luiz de Queiroz", Universidade de São Paulo, para obtenção do título de Mestre em Ecologia de Agroecossistemas.
\end{abstract}

P I R A C I C A B A

Estado de São Paulo - Brasil

Abril - 2004 


\title{
PRODUÇÃO DE MUDAS CÍTRICAS EM VIVEIRO: USO DE SUBSTRATO ALTERNATIVO E INOCULAÇÃO COM Xylella fastidiosa
}

\author{
RONALDO AlBERTo DUENHAS CABRERA \\ Engenheiro Agrônomo
}

Orientadora: Prof. ${ }^{\text {a }}$ Dr. ${ }^{\text {a }}$ SIU MUI TSAI

Dissertação apresentada à Escola Superior de Agricultura "Luiz de Queiroz”, Universidade de São Paulo, para obtenção do título de Mestre em Ecologia de Agroecossistemas.

P I R A C I C A B A

Estado de São Paulo - Brasil

Abril - 2004 
Dados Internacionais de Catalogação na Publicação (CIP)
DIVISÃO DE BIBLIOTECA E DOCUMENTAÇÃO - ESALQ/USP

Cabrera, Ronaldo Alberto Duenhas

Produção de mudas cítricas em viveiro: uso de substrato alternativo e inoculação com Xylella fastidiosa / Ronaldo Alberto Duenhas Cabrera. - -

Piracicaba, 2004.

$106 \mathrm{p}$.

Dissertação (mestrado) - - Escola Superior de Agricultura Luiz de Queiroz, 2004.

Bibliografia.

1. Bactérias fitopatogênicas 2. Citricultura 3. Estufa 4. Fitossanidade 5. Inoculação । Mudas 7. Variedades vegetais I. Título

CDD 634.3

"Permitida a cópia total ou parcial deste documento, desde que citada a fonte - O autor" 
Agradeço a Deus,

Pela vida e a oportunidade de trabalhar em agricultura.

Dedico,

A minha esposa Roberta R. Fernandes Cabrera pelo carinho, apoio, paciência nos momentos de ausência e compreensão da dificuldade de trabalhar e estudar ao mesmo tempo.

A minha filha Amanda Fernandes Cabrera, que é motivo de inspiração para novos projetos e a razão de nunca desistir nos momentos de dificuldade;

Aos meus pais,

José Cabrera Duenhas e Elza Aparecida Trinca Cabrera pelos ensinamentos, princípios familiares e morais transmitidos ao longo dos anos.

Ao meu irmão José Fernando Duenhas Cabrera e sua esposa Paula Rossi Cabrera.

Ao meu sogro Roberto Fernandes Crespo e minha sogra Maria Aparecida de Rossi Fernandes.

Ao meu cunhado Ronaldo de Rossi Fernandes 


\section{AGRADECIMENTOS}

À Coordenadoria do Curso Interunidades - Ecologia de Agroecossistemas CENA / ESALQ, pela oportunidade oferecida.

À Professora Dr. ${ }^{a}$ Siu Mui Tsai, pela orientação, amizade, paciência, disposição e ensinamentos transmitidos.

Ao Professor Dr. ${ }^{\circ}$ Adriano Azevedo Filho, pela amizade, ensinamentos e contribuição para realização deste trabalho.

Ao Dr. ${ }^{\circ}$ Tsuioshi Yamada, pelo apoio, amizade, ensinamentos e contribuição na evolução profissional.

Ao Engenheiro Agrônomo Hélio Casale pela amizade e ensinamentos agronômicos.

À Prefeitura Municipal de Novais,em nome do Prefeito Wlaldir Fuster Pinheiro e sua esposa Dorceli do Carmo Domingues Pinheiro.

Ao Escritório de Desenvolvimento Rural de Catanduva - CATI, em nome do Diretor Mauro Antonio Luchet. 
Aos citricultores Elizeu Gil e irmãos da Fazenda São Domingos, Novais-SP, José Cabrera Duenhas e irmão dos Sitio Jardim, Novais-SP e ao senhor Jorge Murakami.

Aos Colegas do CENA-USP: Wagner Piccinini, Francisco (Chiquinho), Fabiana S. Cannavan, Elias e Fábio. 


\section{SUMÁRIO}

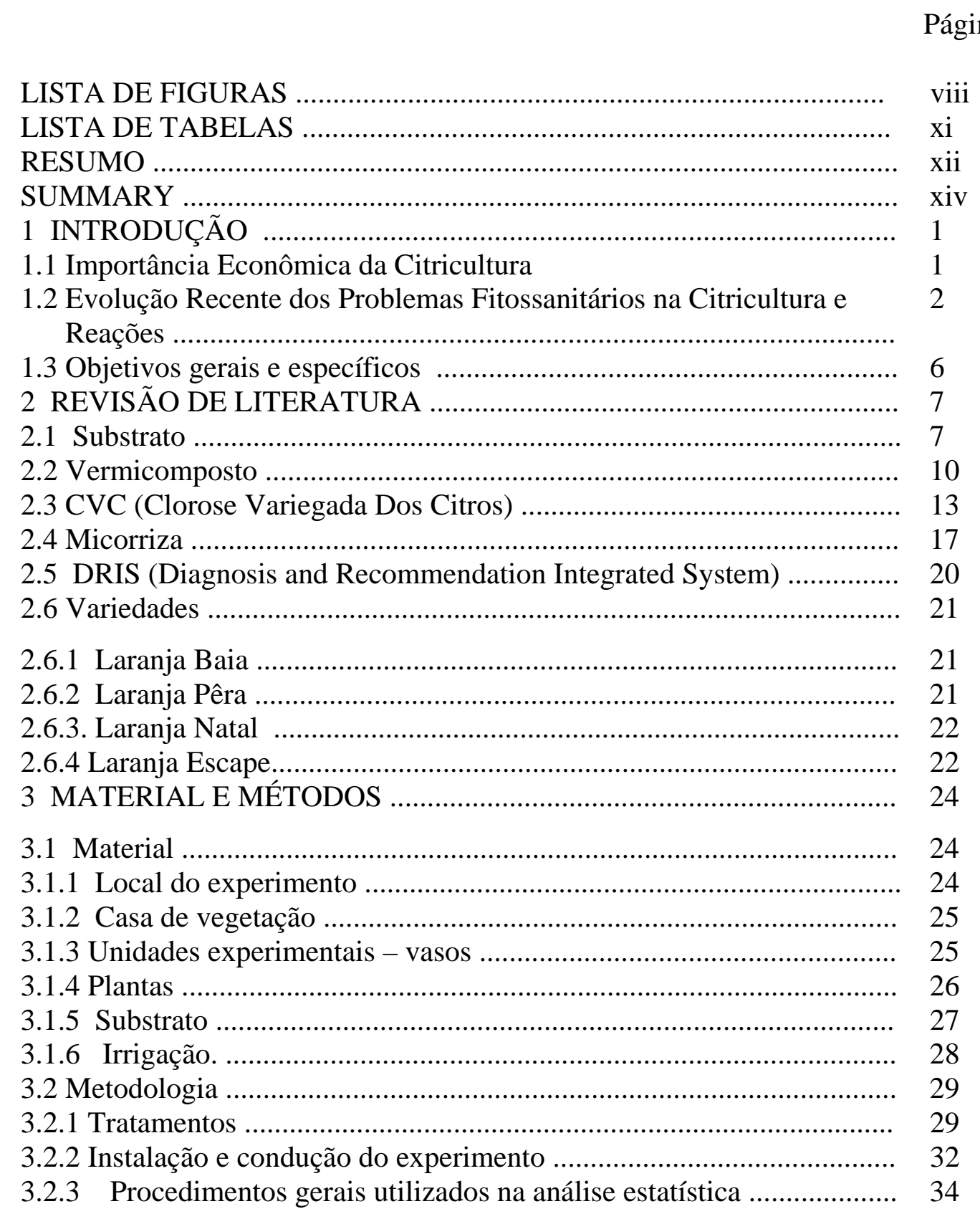




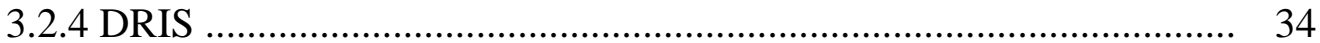

4 RESULTADOS E DISCUSSÃO ...................................................... 35

4.1 Caracterização geral dos resultados ............................................... 35

4.1.1 Impacto no peso da matéria seca da parte aérea (pspa) .................... 35

4.1.2 Impacto no peso da matéria seca da parte radicular (pssr) ............... 38

4.1.3 Impacto no diâmetro do caule a $10 \mathrm{~cm}$ do colo (d) ......................... 40

4.1.4 Impacto na altura da planta (a) ................................................. 42

4.1.5 Impacto na micorrização (mva) .................................................... 44

4.1.6 Impacto no DRIS - Índice de Balanço Nutricional (IBN) ............... 46

4.2 Comportamento de indicadores biométricos (2 a 2) .......................... 48

4.3 Significância estatística dos resultados .......................................... 68

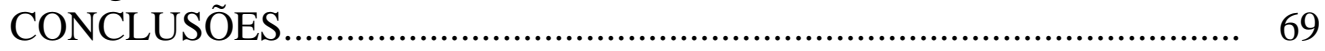

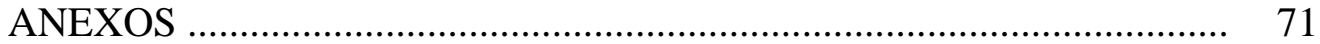

REFERÊNCIAS BIBLIOGRÁFICAS ................................................. 94 


\section{LISTA DE FIGURAS}

1 Planta "Escape” sem sintomas de CVC, rodeada de plantas doentes por CVC

Página

2 Localização geográfica do local onde foi conduzido o experimento .. 24

$3 \quad$ Casa de vegetação onde foi conduzido o experimento ....................... 25

$4 \quad$ Vasos de polietileno, onde foram produzidas as mudas ...................... 26

$5 \quad$ Esboço do croqui do experimento .................................................... $\quad 30$

6 Diagrama de Tuckey do peso da matéria seca da parte aérea (pspa) em gramas, por substrato, variedade e tipo de inoculação.

7 Diagrama de Tukey da matéria seca do sistema radicualar (pssr) em gramas, por substrato, variedade e tipo de inoculação........................

8 Diagrama de Tukey do diâmetro do caule a $10 \mathrm{~cm}$ do colo em milímetros, por substrato, variedade e tipo de inoculação...................

9 Diagrama de Tukey da altura da planta em centímetros, por substrato, variedade e tipo de inoculação.

10 Diagrama de Tukey da micorrização em porcentagem, por substrato, variedade e tipo de inoculação

11 Diagrama de Tukey do Índice de Balanço Nutricional, por substrato, variedade e tipo de inoculação.

12 Diagrama de dispersão do peso seco e regressão da M.S. da parte aérea(g) e do sistema radicular(g), por cultivar, comercial; mmistura; v- vermicomposto substrato (s-substrato-) e tipo de inoculação (cinza-não inoculado preto-inoculado).

13 Diagrama de dispersão do peso seco e regressão da M.S. da parte aérea(g) e do Índice de Balanço Nutricional, por cultivar, substrato (s-substrato comercial; m-mistura; v- vermicomposto) e tipo de inoculação (cinza-não inoculado; preto-inoculado).

14 Diagrama de dispersão do peso seco e regressão da M.S. do sistema radicular (g) e Índice de Balanço Nutricional, por cultivar, substrato (s-substrato comercial; m-mistura; v- vermicomposto) e tipo de inoculação (cinza-não inoculado; preto-inoculado). 
15 Diagrama de dispersão do peso seco e regressão da M.S. do sistema radicular(g) e taxa de micorrização(\%), por cultivar, substrato (ssubstrato comercial; m-mistura; v- vermicomposto) e tipo de inoculação (cinza-não inoculado; preto-inoculado).............................

16 Diagrama de dispersão do diâmetro do caule $(\mathrm{mm})$ e regressão da M.S. do sistema radicular(g), por variedade, substrato (s-substrato comercial; m-mistura; v- vermicomposto) e tipo de inoculação (cinza-não inoculado; preto-inoculado).

17 Diagrama de dispersão do peso seco e regressão da M.S. da parte área (g) e diâmetro do caule(mm), por variedade, substrato (ssubstrato comercial; m-mistura; v- vermicomposto) e tipo de inoculação (cinza-não inoculado; preto-inoculado)

18 Diagrama de dispersão da taxa de micorrização e regressão do Índice de Balanço Nutricional, por cultivar, substrato (s-substrato comercial; m-mistura; v- vermicomposto) e tipo de inoculação (cinza-não inoculado; preto-inoculado)...

19 Diagrama de dispersão do diâmetro do caule $(\mathrm{mm})$ e regressão do diâmetro do caule(mm) e Índice de Balanço Nutricional, por variedade, substrato (s-substrato comercial; m-mistura; vvermicomposto) e tipo de inoculação (cinza-não inoculado; pretoinoculado)....

20 Diagrama de dispersão da altura da planta(cm) e regressão da altura da planta $(\mathrm{cm})$ e Índice de Balanço Nutricional, por variedade, substrato (s-substrato comercial; m-mistura; v- vermicomposto) e tipo de inoculação (cinza-não inoculado; pretoinoculado)

21 Diagrama do teor foliar de fósforo e regressão do teor foliar de fósforo $\left(\mathrm{g} \mathrm{kg}^{-1}\right)$ e taxa de micorrização(\%), por variedade, substrato (s-substrato comercial; m-mistura; v- vermicomposto) e tipo de inoculação (cinza-não inoculado; preto- inoculado).

22 Relação entre teor foliar de macronutrientes na variedade Baia, por substrato e tipo de inoculação (veja texto para detalhes)

23 Relação entre teor foliar de micronutrientes na variedade Baia, por substrato e tipo de inoculação (veja texto para detalhes)...

24 Relação entre teor foliar de macronutrientes na variedade Escape, por substrato e tipo de inoculação (veja texto para detalhes).

25 Relação entre teor foliar de micronutrientes na variedade Escape, por substrato e tipo de inoculação (veja texto para detalhes).

26 Relação entre teor foliar de macronutrientes na variedade Natal, por substrato e tipo de inoculação (veja texto para detalhes)....................

27 Relação entre teor foliar de micronutrientes na variedade Natal, por substrato e tipo de inoculação (veja texto para detalhes). 
28 Relação entre teor foliar de macronutrientes na variedade Pêra, por substrato e tipo de inoculação (veja texto para detalhes)..................... 90

29 Relação entre teores foliares de micronutrientes na variedade Pera, por substrato e tipo de inoculação (veja texto para

detalhes)..................... 


\section{LISTA DE TABELAS}

Página

1 Análise química dos substratos comercial e vermicomposto (na MS.)....... 27

2 Análise química da água de irrigação ...................................................... 28

3 Tratamentos realizados no experimento em casa-de-vegetação.................. 31

4 Procedimentos analíticos de cada mensuração. .......................................... 32

5 Efeito dos tratamentos nos diferentes parâmetros analisados ..................... 68

6 Valores médios de diâmetro do caule, altura da planta, peso da parte aérea, peso do sistema radicular e taxa de micorrização, nos diferentes tratamentos .................................................................................... 73

7 Teores foliares médios de macronutrientes, nos diferentes tratamentos ....... 74

8 Teores foliares médios de micronutrientes, nos diferentes tratamentos....... $\quad 75$

9 Efeito dos tratamentos nos diferentes parâmetros analisados ...................... 93 


\section{PRODUÇÃO DE MUDAS CÍTRICAS EM VIVEIRO: USO DE SUBSTRATO ALTERNATIVO E INOCULAÇÃO COM Xylella fastidiosa}

Autor: RONALDO ALBERTO DUENHAS CABRERA

Orientador: Profa. Dra. SIU MUI TSAI

\section{RESUMO}

Substratos alternativos têm sido usados para promover um melhor estabelecimento de plantas em viveiros, de forma a assegurar que plantas sadias sejam transferidas ao campo. No caso do Citrus spp. Esta preocupação é real pela possibilidade do campo poder apresentar um histórico de doenças na área, tal como a Clorose Variegada do Citros causada pela Xylella fastidiosa (X.f.). Este estudo avaliou a adição de vermicomposto a um substrato comercial e o desenvolvimento de plântulas de quatro variedades de citros inoculadas ou não com X.f. em condições de casa-de-vegetação, por um período de 450 dias. Medidas biométricas do crescimento da planta e o uso de indicadores do balanço nutricional usando o programa DRIS - Diagnosis and Recommendation Integrated System foram aplicadas em plantas de 9 meses de idade. As variáveis estudadas foram: substrato vermicomposto $(100 \%, 50 \%, 0 \%)$, variedade (Baia, Pêra, Natal e Escape) e inoculação (com ou sem X.f.) em um total de 24 tratamentos (variedade $\mathrm{x}$ substrato $\mathrm{x}$ inoculação), com seis repetições. Quanto ao desenvolvimento das plantas, avaliou-se o diâmetro do caule, a altura da planta, a produção de biomassas das raízes e partes aéreas, a taxa de infecção natural por fungos micorrízicos naturais do solo, a concentração de macro e micronutrientes na parte aérea. 
Quando se usou vermicomposto (100\% or 50\%), efeitos positivos foram observados nos parâmetros de desenvolvimento das plantas. Por outro lado, a infecção micorrízica e DRIS foram inversamente correlacionadas indicando estar ocorrendo um desbalanço nutricional neste estádio de desenvolvimento das plantas. Não foi observado um efeito significativo da inoculação com X.f. no desenvolvimento das plantas ou mesmo nos parâmetros biométricos, exceto para os teores foliares de nitrogênio e fósforo, onde nas plantas inoculadas o teor foliar de nitrogênio (1,46\%) foi maior em relação às plantas não inoculadas (1,30\%) e para fósforo ocorreu o oposto $(0,32 \%$ e $0,40 \%$, respectivamente). 


\title{
PRODUCTION OF CITRUS SEEDLINGS IN NURSERY: USE OF ALTERNATIVE SUBSTRATUM AND INOCULATION WITH Xylella fastidiosa
}

\author{
Author: RONALDO ALBERTO DUENHAS CABRERA
}

Adviser: Profa. Dra. SIU MUI TSAI

\section{SUMMARY}

Alternative substrates have being used for a better establishment of plants at nursery stages, thus ensuring that healthier plants will be transferred to the field. In the case of Citrus, this is a concern especially when there is a past history of diseases at field conditions, such as Citrus Variegated Chlorosis caused by Xylella fastidiosa (X.f.). This study evaluated the addition of vermicompost to a commercial substrate and the performance of seedlings of four citrus varieties inoculated or not with $X$. $f$. at greenhouse condition, for a period of 450 days. Biometric measurements of plant growth and nutritional balance indicators using DRIS - Diagnosis and Recommendation Integrated System were performed in 9 month-old plants. Mycorrhizal infection by native vesicular-arbuscular fungi was also evaluated in all plants. The studied variables were: vermicompost substrate (100\%, 50\%, 0\%), variety (Baia, Pêra, Natal and Escape) and inoculation (with or without X.f.), in a total of 24 treatments (variety x substrate $x$ 
inoculation) with 6 replicates each. Growth development evaluated stem diameter, plant height, shoot and root biomass accumulations, arbuscular mycorrhizal infection, and macro and micronutrient concentration in the shoot. When using vermicompost (100\% or $50 \%$ ), positive effects were observed in the plant growth parameters. On the other hand, mycorrhizal infection and DRIS were inversely correlated to the substrate addition, indicating that nutrient imbalances may be occurring at this plant growth stage. No significant effect of X.f. inoculation was observed on the plant growth and the biometric parameters studied, except for increased foliar nitrogen content - 1,46\% for inoculated and 1,30\% for uninoculated plants, and decreased foliar phosphorus content $0,32 \%$ for inoculated and $0,40 \%$ for uninoculated plants. 


\section{INTRODUÇÃO}

O presente trabalho investiga impactos técnicos, econômicos, nutricionais e biológicos de diferentes substratos na produção de mudas cítricas de quatro variedades comerciais utilizados na citricultura brasileira. Verifica, também, possíveis efeitos da inoculação das mudas com a bactéria Xylella fastidiosa, assim como a taxa de micorrização observada nas diferentes condições consideradas. Os impactos nutricionais dos vários tratamentos consideraram indicadores desenvolvidos a partir da metodologia DRIS (Diagnosis and Recommendation Integrated System).

A pesquisa é motivada pela necessidade de racionalização do processo de produção de mudas dentro do novo modelo que vem sendo implantado dentro da citricultura do estado de São Paulo com o objetivo de promover padrões fitossanitários mais evoluídos, de forma a minimizar potenciais problemas decorrentes da CVC e outras pragas e doenças.

Visando situar a pesquisa dentro de um contexto mais amplo é apresentada, nas próximas seções, uma caracterização da importância econômica da citricultura paulista e dos problemas que condicionaram alterações profundas no sistema de produção de mudas cítricas, ao longo dos últimos anos. Finalmente, na última seção deste capítulo, são detalhados os objetivos específicos da pesquisa.

\subsection{Importância Econômica da Citricultura}

A citricultura é um segmento da economia nacional que ocupa o $4^{\circ}$ lugar na pauta de exportações brasileiras, gera 400 mil empregos diretos 1,2 milhão de empregos indiretos, movimentando cerca de U\$ 5 bilhões anuais na cadeia sendo U\$ 1,10 bilhão só em exportação de suco concentrado. No Estado de São Paulo está presente, de forma 
significativa, na economia de mais de 300 municípios, distribuindo renda através dos mais de 15 mil citricultores, a grande maioria pequenos produtores (Associtrus, 2004).

Os citricultores brasileiros enfrentam sérios problemas, como barreiras alfandegárias, problemas climáticos (déficit hídrico) principalmente na região norte do estado de São Paulo e Triângulo Mineiro, CVC e mais recentemente a Morte Súbita dos Citros (MSC).

\subsection{Evolução Recente dos Problemas Fitossanitários na Citricultura e Reações}

A CVC foi detectada no ano de 1987, nos pomares de laranja das regiões norte e noroeste do estado de São Paulo e ficou popularmente conhecida como “Amarelinho”. Esta doença se disseminou rapidamente, atingindo boa parte do parque citrícola (Machado et al., 1992).

Segundo o levantamento atual disponível na página da internet do Fundecitrus (novembro 2003), 36,44 \% das plantas do estado de São Paulo estão com CVC, sendo que por região a distribuição é a seguinte: região norte: 48,6 \%, região noroeste: 40,85 \%, região central: $39,01 \%$ e região sul: 17,33 \%.

Recentemente surgiu uma nova doença na citricultura brasileira MSC (Morte Súbita dos Citros), que possivelmente é um mutante do vírus da tristeza que ataca as combinações com o limoeiro 'Cravo'. O limoeiro 'Cravo' é o porta enxerto mais utilizado, representando mais de $80 \%$ das plantas do parque citrícola brasileiro. Esta doença está concentrada no Triângulo Mineiro e região norte do estado de São Paulo, que são as mesmas regiões onde ocorre a maior incidência de CVC, isto reforça a hipótese de que há necessidade de melhoria de manejo nestas regiões.

Por outro lado, a citricultura paulista está estabelecida em solos com baixos teores de matéria orgânica: ao redor de $15 \mathrm{~g} \mathrm{~kg}^{-1}$ na camada de $0-20 \mathrm{~cm}$ e de $12 \mathrm{~g} \mathrm{~kg}^{-1}$ na camada de 20-40 cm (Quaggio, 1996). Esta pobreza em matéria orgânica contrasta bastante com a observada na citricultura chinesa por Moreira et al. (1989). Segundo estes autores, os pomares são fertilizados principalmente com adubos orgânicos de origem animal. 
O uso de materiais orgânicos na China seria na opinião de Kelman \& Cook (1977) uma das razões para a ausência generalizada de importantes doenças radiculares nas culturas daquele país. No Brasil a situação é bem diferente, pois de acordo com Neves (2000), na decomposição dos custos operacionais em despesas com mão-de-obra, serviços de máquinas, adubos, corretivos e defensivos, este último chega a $40 \%$ em determinadas regiões.

Nos últimos anos o sistema de produção de citros no Brasil sofreu grandes alterações, como por exemplo, maior uso de micronutrientes via solo, manejo de mato, diversificação de porta-enxertos, uso mais freqüente de irrigação e produção de mudas em ambiente protegido. Isso tem levado a pesquisa brasileira intensificar os trabalhos no sentido de adequar o nível tecnológico para manter o Brasil na liderança de maior produtor mundial de laranja.

O advento da Clorose Variegada dos Citros (CVC) associada à bactéria Xylella fastidiosa (Leite et al.,1991), cujos vetores principais são as cigarrinhas Dilobopterus costalimai, Acrogonia terminalis e Oncometopia facialis (Roberto et al., 1996), motivou alterações no sistema de produção de mudas cítricas no estado de São Paulo.

Com a nova norma legislativa em vigor para produção de mudas cítricas fiscalizadas, tornou-se obrigatória a produção de mudas cítricas em ambiente protegido e em vasos. Em função da necessidade de organização do setor de produção de mudas, foi criada a Associação dos Viveiristas do Estado de São Paulo (Vivecitrus). Esta organização denota a importância deste setor para a citricultura paulista, pois se preocupa com aspectos como, por exemplo, o padrão de qualidade genético e sanitário no viveiro e dos pomares implantados a partir destas mudas, qualidade dos substratos e das várias técnicas empregadas durante o processo de produção.

Fato semelhante também ocorreu na citricultura da África do Sul, com o surgimento do “Greening”, uma doença também provocada por bactéria gram negativa, restrita ao floema, conhecida como Liberobacter africanum, cujo vetor é o psilídeo Trioza erytrea. No ano de 1973, os citricultores daquele país também adotaram o sistema de produção de mudas em ambiente protegido (Roux et al., 1998). 
Todos os viveiros comerciais da África do Sul participam do esquema de produção de mudas sadias, onde utilizam material propagativo controlado pelo programa. As mudas são produzidas em regiões isentas da doença, utilizam estufas com telas anti-psilídeos, com dupla porta de entrada e saída de mudas de dentro para fora do viveiro (Roux et al., 1998).

No passado, quando as mudas eram cultivadas diretamente no solo, o volume explorado pelo sistema radicular era muito maior do que nos vasos de polietileno que atualmente são empregados. Quando surgiam os problemas havia mais tempo para solucioná-los, mas no sistema moderno este tempo é reduzido em $60 \%$, não permitindo erros durante o processo de produção, dependendo do erro é impossível corrigir. Isso exige um conhecimento técnico maior por parte do viveirista e a pesquisa agronômica precisa acompanhar a evolução deste sistema.

Quando avaliamos o custo de produção de mudas cítricas em ambiente protegido, o tempo de formação da muda é muito importante na determinação do custo de produção. Diminuindo o tempo de permanência da muda no viveiro, aumenta o número de ciclos de produção durante a vida útil da estrutura física, aumenta a eficiência da utilização de mão de obra, reduzindo gastos com defensivos agrícolas e fertilizantes.

Os primeiros viveiristas que adotaram o sistema de produção de mudas em vasos, utilizavam substratos manipulados na própria fazenda. Estes substratos eram produzidos com matéria prima local, como por exemplo, terra de barranco, esterco bovino, esterco de galinha, areia grossa, bagaço de cana, casca de arroz carbonizada, composto orgânico, húmus de minhoca e outros materiais de custo menor e com boa disponibilidade.

Atualmente, a maioria dos viveiristas utiliza substrato comercial, como por exemplo Plantmax, Terra do Paraíso, Klabin, Vida Verde e outras marcas comerciais. O substrato participa em $18 \%$ do custo de produção da muda, além do fato de haver necessidade de adubações complementares. Também existem substratos alternativos como fibra de coco e turfa, sendo que este último é extraído de áreas de preservação permanente, o que dificulta sua disponibilidade.

O custo de produção da muda de laranja, segundo dados obtidos na pesquisa, é de aproximadamente R\$2,00 (dois reais) ou U\$ 0,70 (setenta centavos de dólar), sendo 
que deste custo, 20 \% é substrato e 14\% adubação, totalizando 34\% do custo. Se os viveiristas utilizarem substratos melhores poderão reduzir o custo de adubação (14\%).

Observa-se na literatura, pouca informação disponível sobre os sistemas de produção de mudas envasadas, havendo muitas questões e dúvidas a respeito dos métodos de adubação (adubos de liberação lenta, fertirrigação, adubação sólida, adubações foliares), adubações especificas para cada tipo de porta enxerto empregado, e manejo quanto o método de irrigação. De fato, cada viveirista adota sua própria metodologia, sendo que suas opiniões são divergentes.

O preço médio de uma muda de laranja é de U\$ 1,75 (um dólar e setenta e cinco centavos), com um custo de produção de U\$ 0,70 (setenta centavos de dólar), então o negócio produção de mudas é uma atividade lucrativa, permitindo maiores erros e conseqüentemente maior custo de produção. Com o aumento da oferta a tendência é que reduza o preço, com isso será obrigatório otimizar o sistema de produção de mudas. Segundo o Informativo $\mathrm{n}^{0} 11$ da Vivecitrus (2003), a capacidade produtiva instalada é de 24 (vinte e quatro) milhões de mudas por ano e a demanda é de 10.8 (dez ponto oito) milhões de mudas, conseqüentemente nos próximos anos haverá um excedente de 11.2 (onze ponto dois) milhões de mudas, caso seja explorada toda a capacidade produtiva dos viveiros já instalados.

Esta divergência reflete nos mais diferentes resultados obtidos quanto ao tempo de formação da muda, uniformidade das mudas, pegamento da enxertia, taxa de descarte, problemas fitossanitários, desbalanços nutricionais, custos, rentabilidade e qualidade dos pomares implantados a partir de mudas produzidas por diferentes métodos.

Para diminuir o período de formação da muda, a qualidade do substrato empregado é de extrema importância, além de reduzir o custo de produção reduz também o impacto que as mudas sofrem no período de adaptação inicial, do transplantio ao pegamento no campo. 


\subsection{Objetivos gerais e específicos}

Dentro da realidade descrita nas seções anteriores, urge conhecer muito bem o substrato a ser empregado no processo de produção de mudas, pois este refletirá diretamente no custo de produção, na sanidade e na qualidade dos novos pomares que serão implantados. Desta forma, foram definidos os seguintes objetivos específicos para a pesquisa:

a) Determinar as vantagens nutricionais e microbiológicas na formação de mudas cítricas enxertadas sobre limoeiro Cravo (Citrus limonia Osbeck cv. Cravo), produzidas em viveiro telado, usando como substrato vermicomposto, substrato comercial e a mistura de ambos, na relação 1:1 (em termos volumétricos);

b) Avaliar a contribuição de diferentes substratos na produção e desenvolvimento de mudas cítricas em vasos, quanto aspectos microbiológicos (presença da micorrização natural) e nutricionais;

c) Avaliar o efeito da inoculação de Xylella fastidiosa no desenvolvimento e estado nutricional das plantas nos diferentes substratos;

d) Avaliar o comportamento das seguintes variedades de citros: laranja Baia, laranja Natal, laranja Pêra e laranja Doce "Escape”; 


\section{REVISÃO DE LITERATURA}

Para melhor embasar a pesquisa, foi realizada uma revisão bibliográfica de trabalhos publicados sobre assuntos relevantes, com foco na literatura do Brasil e dos EUA. Os temas revisados, apresentados nas próximas seções, incluem: substrato, vermicomposto, CVC - Clorose Variegada dos Citros, micorrização, DRIS - Diagnosis and Recommendation Integrated System e variedades cítricas.

\subsection{Substrato}

O termo substrato se aplica a todo material sólido, natural ou sintético, bem como residual ou ainda mineral orgânico, distinto do solo, que colocado em um recipiente em forma pura ou em mistura permite o desenvolvimento do sistema radicular, desempenhando, portanto um papel de suporte para a planta (Abad \& Noguera, 1988).

O sistema de produção de mudas em vasos em ambiente protegido, tem como vantagem a redução do tempo de formação da muda, maior controle da adubação e a diminuição dos problemas com pragas e doenças, segundo Moss (1978) e Willianson \& Castle (1989).

O volume do vaso é um fator limitante para o desenvolvimento do sistema radicular da muda cítrica, influenciando no crescimento das raízes e da parte aérea (Spomer, 1982). O volume explorado no vaso não se compara ao volume explorado pela planta no viveiro a campo (Pereira, 1983).

Na escolha do substrato deve-se levar em conta disponibilidade de nutrientes e as propriedades físicas, sendo recomendável à suplementação com fertilizantes quando o substrato utilizado é de baixa fertilidade (Souza, 1983). Blom (1983) relata a importância da densidade do substrato e do custo de sua aquisição. O substrato deve 
suprir as necessidades físicas, químicas e conter uma proporção significativa de ar, água e nutrientes essenciais, para que proporcione à planta um bom desenvolvimento e crescimento (Riviere, 1980).

Componentes dos substratos com alta relação carbono/nitrogênio, necessitam de suplementação com adubos químicos nitrogenados, para acelerar a decomposição destes materiais, sem que ocorra concorrência com a planta (Instituto Brasileiro do Café, 1985). Utilização de materiais orgânicos como integrantes de substratos, não somente fornece nutrientes, como também tem efeito sobre a atividade microbiana, aeração, estruturação, capacidade de retenção de água, capacidade de troca catiônica e atua na regulação da temperatura do meio (Pons, 1983).

A superioridade das plantas conduzidas em diferentes substratos, dependerá das propriedades do substrato, como por exemplo, firmeza, volume relativamente constante quando seco e úmido, capacidade de retenção de água, porosidade, drenagem, aeração, sanidade, baixo nível de salinidade e boa disponibilidade de nutrientes (Hartmann e Kester, 1975).

Um substrato padrão deve ter baixa densidade, boa fertilidade, composição química e física uniforme, elevada capacidade de troca de catiônica, boa capacidade de retenção de água, boa aeração e drenagem, boa coesão entre as partículas ou aderência junto às raízes e ser preferencialmente um meio estéril (Coutinho \& Carvalho, 1983).

Segundo Roux et al. (1998), na África do Sul, o substrato utilizado predominantemente para produção de mudas cítricas, tem como base: casca de Pinus, areia grossa ou mistura de ambos. De acordo com Coetzee, citado por Roux et al. (1998), os citros reagem favoravelmente em meios com porosidade de ar entre 12 e 20 \%, a capacidade de retenção de água pode variar de 150 a $550 \mathrm{ml} \mathrm{l}^{-1}$ do meio (Lee, citado por Roux et al., 1998). Um meio balanceado entre porosidade de ar e capacidade de retenção de água, assegura oxigênio suficiente para a respiração das raízes. Substratos com drenagem deficiente favorecem a infecção por Phythophthora e Fusarium nas raízes. Devem ser estáveis em suas propriedades físicas e não facilmente quebrada por microorganismos, se isso ocorrer, haverá colapso das estruturas, compactação, diminuição da aeração e encharcamento (Roux et al., 1998). 
Quando se usa matéria orgânica como constituinte de substratos não se deve descuidar de doenças fúngicas (Donadio, 1986). A presença de matéria orgânica na constituição do substrato é muito importante, mas em teores elevados, pode favorecer a infecção do sistema radicular dos citros por fungos presentes na mesma (Pompeu Junior, 1980).

Toledo (1992) estudou o efeito de substrato na formação de mudas de laranja, onde testou a mistura de vários substratos alternativos. Os tratamentos empregados foram: T1- solo $60 \%$ e areia $40 \%$, T2- solo $40 \%$ e areia $60 \%$, T3- solo $40 \%$ e bagaço de cana $60 \%$, T4- solo $60 \%$ e vermiculita $40 \%$, T5- solo $20 \%$, bagaço de cana $40 \%$ e plantmax 40\%, T6- solo 30\%, areia 20\%, bagaço de cana $20 \%$ e plantmax $30 \%$, T7- solo $40 \%$, areia $40 \%$ e plantmax $20 \%$ e T8- solo $30 \%$, areia $40 \%$ e vermicomposto $30 \%$. O substrato com a mistura de $30 \%$ de solo, $40 \%$ de areia e $30 \%$ de vermicomposto foi o que apresentou os maiores valores para altura da planta e diâmetro do caule, a superioridade deste substrato foi devido aos benefícios do componente vermicomposto (húmus de minhoca).

Segundo Mattos Júnior et al. (1995), na formação de mudas cítricas de limoeiro Cravo e tangerina Cleópatra, quando se utilizam substratos com teores de boro extraídos em água quente, superiores a $5 \mathrm{mg} \mathrm{dm}^{-3}$, proporcionam teores foliares superiores a 280 $\mathrm{mg} \mathrm{kg}^{-1}$, com sintomas de toxidade.

O substrato influencia significativamente a arquitetura do sistema radicular e no estado nutricional das plantas (Spurr e Barnes, 1973).

Entre as características desejáveis nos substratos, pode-se citar o custo, disponibilidade, teor de nutrientes, capacidade de troca de cátions, esterilidade biológica, aeração, retenção de umidade e uniformidade (Gonçalves, 1985).

Como já foi mencionado, existem limitações na literatura quanto ao fornecimento de informações precisas sobre os melhores substratos para produção de mudas cítricas em vasos e os resultados existentes a respeito das práticas empregadas correntemente também são escassos, tornando necessário investigar mais profundamente este assunto. 


\subsection{Vermicomposto}

Segundo Antoniolli et al. (1995), vermicomposto é o nome dado ao composto orgânico transformado em húmus pela ação de minhocas.

De acordo com Vieira (1993), as minhocas são classificadas na escala zoológica, da seguinte maneira:

Filo = Annelida (de annelus, pequeno anel);

Classe = Oligochaeta - minhocas. Nesta classe há mais de 2000 espécies;

Ordem $=$ Allolobophora

As minhocas mais criadas são Eisenia foetida, (minhoca dos montes de esterco), a Lumbricus rebellus (minhoca dos resíduos orgânicos), ambas conhecidas como minhocas vermelhas ou da Califórnia, embora sejam de origem européia e Eudrilus eugeniae, a minhoca gigante africana (Vieira, 1993). O vermicomposto é enriquecido com os coprólitos das minhocas, contendo microrganismos humificantes alcalinos e bactérias, que possuem ação semelhante a anticorpos naturais contra pragas e doenças, conferindo saúde às plantas.

Húmus de minhoca também conhecido como vermicomposto, é resultado dos excrementos do aparelho digestivo da minhoca (coprólitos), com altos teores de matéria orgânica e sais minerais. Durante o processo de produção as minhocas estabilizam os materiais orgânicos e estes por sua vez apresentam maior quantidade de carbono na forma humificada. (Aquino et al., 1994).

O vermicomposto produzido pelas minhocas, em média é setenta por cento mais rico em nutrientes que os substratos húmicos convencionais, por exemplo, os produzidos através de sistemas aeróbicos de compostagem. Sua riqueza em bactérias e microorganismos facilita a assimilação dos nutrientes pelas raízes, apresentando ainda a vantagem de ser neutro, uma vez que as minhocas possuem glândulas calcíferas que transformam o húmus e a matéria orgânica utilizada em material neutro, corrigindo assim, ou pelo menos facilitando, a correção do solo (Longo, 1987). 
Segundo Albanell et al. (1988), durante o processo de alimentação, as minhocas fragmentam o substrato, acelerando a taxa de decomposição da matéria orgânica, alterando física e quimicamente o material, onde a matéria orgânica instável é oxidada e estabilizada. Nos vermicompostos os sais solúveis são reduzidos, a capacidade de troca de cátions e a quantidade de ácidos húmicos são aumentadas.

De acordo com Atiyeh et al. (2000), que estudaram em tomateiro em casa de vegetação, a influência de várias doses de vermicomposto de suínos no substrato. Trabalharam com substrato comercial e substituíram 10\%, 20\%, 30\%, 40\%, 50\%, 60\%, $70 \%$, 80\%, 90\% e 100\% por vermicomposto. As respostas positivas ocorreram nas proporções de 10 a $40 \%$ de vermicomposto no substrato. Este resultado positivo foi devido às alterações físico-químicas e microbiológicas do substrato, além do fornecimento de nitrogênio. Proporções maiores provocaram declínio na produção, principalmente devido à redução na aeração e porosidade do substrato, aumento das concentrações salinas ou presença de substancias tóxicas.

Atiyeh et al. (2002) estudaram a influência de ácidos húmicos derivados de vermicomposto de resíduos orgânicos no desenvolvimento de plantas de tomate e abóbora. Foi adicionado ao substrato 0, 50, 100, 150, 200, 250, 500, 1000, 2000 e 4000 mg de humato por quilograma de substrato. Houve incremento no peso da matéria seca das plantas, área foliar, peso da matéria seca dos ramos e raízes. As respostas foram positivas nas doses de 50 a $500 \mathrm{mg} \mathrm{kg}^{-1}$, mas decresceu quando as doses ultrapassaram 500 a $1000 \mathrm{mg} \mathrm{kg}^{-1}$. O autor desse trabalho sugere que esta resposta positiva de 50 a 500 mg kg-1 provavelmente decorre da atividade hormonal dos ácidos húmicos provenientes do vermicomposto.

Grappelli et al. (1987) relatam que os vermicompostos contêm substâncias que ativam biologicamente a planta, como por exemplo reguladores de crescimento.

O emprego de matéria orgânica na adubação, faz com que as plantas se desenvolvam fortes e resistentes, reativando o ciclo biológico natural do solo, isso reduz significativamente as infestações de pragas, diminui perdas e despesas com agrotóxicos (Longo, 1987). 
Segundo Gonçalves \& Poggiani (1996), quando o vermicomposto é utilizado como substrato para essências florestais, apresenta inúmeras vantagens, entre elas, boa consistência dentro de recipientes, boa porosidade e drenagem, alta capacidade de retenção de água e nutrientes, alta capacidade de troca de cátions, elevada fertilidade e boa formação do sistema radicular

Tedesco et al. (1999), estudaram a produção de mudas de Jacaranda micrantha Chamisso (Caroba) em tubetes, e avaliou a mistura de substrato à base de casca de Pinus $s p$ mais vermiculita com 20\%, 40\%, 60\% e 80 \% de vermicomposto. Os parâmetros analisados foram diâmetro do tronco, altura da planta, peso da matéria seca da parte aérea, peso da matéria seca do sistema radicular e matéria seca total. Para todos os parâmetros houve resposta positiva à medida que aumentou a proporção de vermicomposto na constituição do substrato.

A ação das minhocas no composto é mecânica e biológica, sendo a primeira mais representativa. O efeito bioquímico, está na decomposição da matéria orgânica pelos microorganismos existentes no intestino das minhocas. O material dejetado está em estado mais avançado de decomposição, onde a assimilação pelas raízes é facilitada. Essas dejeções são pobres em argila e ricas em matéria orgânica, nitratos, fósforo, potássio, cálcio e magnésio, apresentando alta capacidade de troca de cátions (CTC) e saturação em bases (V\%), com elevada porcentagem de umidade equivalente (Kiehl, 1985).

As minhocas promovem a mistura da matéria orgânica com a fase mineral, formando agregados homogêneos humo-argilosos de 1,5 a 3,0 mm de diâmetro (Primavesi \& Covolo, 1968). Peixoto (1996) relata que tão importante quanto o fornecimento de nutrientes pela matéria orgânica, são suas propriedades coloidais que atuam como agregantes de partículas, favorecendo o arejamento e a friabilidade do substrato. Trocme \& Gras (1979) afirmam que a matéria orgânica influencia muitos aspectos, modificam a estrutura do solo, liberam nutrientes e produzem substâncias estimulantes ao crescimento. Os produtos intermediários da decomposição da matéria 
orgânica têm ação importante sobre a estabilização da estrutura do solo, embora seja de curta duração.

Alves \& Passoni (1997) observaram maior crescimento em altura das mudas de Licania tomentosa BENTH (Oiti), quando cultivadas em substratos adicionados com composto ou vermicomposto de lixo urbano. Houve um crescimento linear das mudas para proporções crescentes de composto ou vermicomposto. Mesmo nas doses mais elevadas de composto ou vermicomposto de lixo urbano, ou ainda na substituição total, não ocorreram problemas de germinação ou desenvolvimento das mudas de Oiti.

\subsection{CVC (Clorose Variegada Dos Citros)}

Atualmente a CVC é considerada uma das mais importantes doenças da citricultura brasileira, haja visto que estudos sugerem que mais de 1/3 das plantas dos estado de São Paulo estão infectadas pela doença, segundo Fundecitrus (novembro 2003).

A doença foi detectada inicialmente na região norte do estado de São Paulo e Triângulo Mineiro, e mais tarde diagnosticada no Rio de Janeiro (Lee et al., 1991), no Paraná por (Leite et al., 1993), Mato Grosso do Sul, Goiás, Sergipe, Santa Catarina (Tubelis, 1993) e Zona da Mata em Minas Gerais (Mizubuti et al., 1994).

A CVC é resultado da presença da bactéria Xylella fastidiosa no xilema das plantas afetadas, podendo causar entupimento dos vasos xilemáticos. Sabe-se que o aparecimento dos sintomas está associado a fatores ambientais, pois plantas resistentes à CVC já foram relatadas, mas estas são aparentemente iguais às plantas suscetíveis do ponto de vista genético, o que fortalece a hipótese de variação ambiental, sem no entanto, haverem sido descritos esses fatores ambientais (Lacava, 2000).

Esta ausência de diferenças genéticas entre as plantas sintomáticas e assintomáticas deve ser estudada mais profundamente, pois em citros são comuns as mutações somáticas Moreira \& Pio (1991), que aumentam a variabilidade genética dos pomares. Com técnicas modernas de engenharia genética é possível isolar os fatores genéticos dos fatores ambientais. Mas um ponto que evidencia a influência ambiental na 
doença são os diferenciais de severidade dos sintomas nas diferentes regiões do estado, onde a medida que se caminha da região sul para a região norte ocorre um aumento significativo dos sintomas.

Conforme Lee et al. (1992) todas as variedades de laranja doce são suscetíveis a CVC, e a maioria das outras espécies de citros como limões, lima ácida e tangerinas, são tolerantes ou resistentes.

Os porta enxertos Citrus reshni, C. sunki, C. limonia, C paradisi x C. trifoliata também são afetados. Em tangerinas comerciais Cravo, Poncan, Tangor, Murcote não foram encontrados sintomas (Laranjeira et al., 1998).

A CVC é uma doença aparentemente causada pela bactéria gram-negativa Xylella fastidiosa, a qual é limitada ao xilema do hospedeiro (Rossetti e De Negri, 1990). No Brasil, a CVC foi descrita em 1987 por Rossetti e De Negri (1990). O isolamento da bactéria em plantas infectadas foi feito por Leite Jr. \& Leite (1991). Posteriormente foi verificada a presença desta bactéria em café e em diversas plantas daninhas herbáceas associadas à cultura dos citros. A interação hospedeiro-bactéria tem sido estudada tanto intra quanto interespecificamente para elucidação da evolução da doença nas diversas culturas.

Os danos provocados pela Xylella fastidiosa são conhecidos na agricultura. Além dos danos associados à CVC, também pode provocar danos a outras culturas economicamente importantes como o Mal de Pierce em videira (PD) Davis et al. (1978), Escaldadura da Folha em Café (CLS) Paradella Filho et al., (1995), Escaldadura da Folha em ameixa (EFA) Carvalho \& Souza (1991), e em outras culturas como pessegueiro e amendoeiras, por exemplo.

Recentemente houve um grande projeto cientifico com apoio da Fundação de Amparo à Pesquisa do Estado de São Paulo (FAPESP), onde o genoma da Xylella fastidiosa foi completamente seqüenciado. Este trabalho objetivou o desenvolvimento de novas tecnologias para prevenção e controle das doenças causadas por esta bactéria. Com o resultado do trabalho de mapeamento genético da Xylella fastidiosa, atualmente sabemos que ela possui quase 2,7 milhões de pares de bases (pb) em seu cromossomo circular (Lambais et al., 2000). Dentro desses pares de bases estão cerca de 2.900 
genes, dos quais $47 \%$ estão com suas funções elucidadas (Revista Pesquisa FAPESP julho 2000). Também apresentam dois plasmídeos com 158pb e 1285pb (Lambais et al., 2000).

Dentro destes 2.900 genes, foram detectados vários deles com função conhecida em outros organismos que devido à homologia encontrada na Xylella, sugerem que apresentem função similar. Dos genes encontrados alguns foram associados a patogenicidade, porém testes "in vivo" devem ser realizados para que se possa afirmar se estes genes são expressos (Lambais et al., 2000).

Os sintomas causados pela infecção de Xylella fastidiosa são variados de acordo com o tipo da planta que ela ataca, os mais comuns são escaldadura das folhas, requeima, nanismo, enfezamento que resulta em frutos pequenos e clorose variegada nas folhas dos citros. Os frutos apresentam maturação precoce com redução de tamanho, enrijecimento da casca que pode causar danos às máquinas utilizadas no processo de extração do suco (Beretta et al., 1996).

De acordo com Machado et al. (1992), os sintomas detectados em laranja doce, são a redução do desenvolvimento da copa, as folhas maduras tornam-se cloróticas e as lesões podem se desenvolver na face ventral com presença de cortiça e goma. As folhas e frutos têm o desenvolvimento retraído, ficando pequenos. Nos frutos, além da redução de tamanho, também ocorre o amarelecimento precoce, endurecimento da casca e surgimento de lesões marrom escuro, formando uma placa de queimadura.

Segundo Donadio et al. (1997), Lee et al. (1991) e Rossetti \& De Negri (1990) os principais sintomas encontrados são clorose nas folhas maduras das copas, apresentando pontuações circulares e amareladas na face superior, e na face inferior apresentam lesões de cor palha e às vezes com necrose. À medida que a doença se agrava, nos frutos ocorre queimadura pelo sol, reduz o tamanho, endurecem com maturação precoce, ficando imprestáveis ao consumo. Como a bactéria da CVC é fastidiosa então os sintomas tardam a aparecer, e geralmente iniciam nas folhas, depois aparecem nos frutos e finalmente toda planta fica tomada. A agressividade da doença é maior quando atinge plantas jovens, diminuindo a severidade à medida que as plantas vão envelhecendo (CVC). 
De acordo com Laranjeira (2002) existem diferenças de comportamento entre as variedades de laranja Doce que foram separadas em três grupos:

Grupo 1 - Altamente suscetíveis: Barão, Pêra, Lima, Rubi, Cadenera 17 e 51, Berna e Valência;

Grupo 2 - Suscetíveis: Gardner, Pineapple, Sunstar, Folha Murcha e Baianinha;

Grupo 3 - Moderadamente suscetíveis: Lue Gim Gong e Westin.

Quanto às variedades de porta enxerto utilizado, confirmou-se apenas em duas seleções de limão Rugoso como hospedeiras de Xylella fastidiosa (Laranjeira et al. 1995). Todos os testes efetuados com o limoeiro Cravo indicam como não hospedeiro desta bactéria (Machado et al., 1993).

Em plantas atacadas por CVC ocorre diminuição em termos de massa e número de frutos. Plantas sadias produziram de 30 a 35\% a mais do que as doentes (Palazzo \& Carvalho, 1993). Laranjeira \& Palazzo (1999) estudaram os danos qualitativos à produção de laranja Natal com CVC, observando que os frutos doentes possuem Brix maior, o que deve ser um efeito de concentração, pois os sólidos totais também são menores, então possivelmente a doença afeta a fotossíntese e o transporte de água na planta.

Conforme Laranjeira \& Palazzo (1994) os sintomas que alteram as características do fruto é resultado maior do déficit hídrico do que propriamente atuação direta do metabolismo da planta, ou seja, o aumento no teor de sólidos solúveis é típico de déficit hídrico, que também afeta plantas normais.

Queiroz-Voltan \& Paradella Filho (1999) estudaram a caracterização de estruturas anatômicas de citros infectados com Xylella fastidiosa. Nos ramos com sintoma, ocorre uma deposição de goma nos vasos do xilema de frutos, caule, pecíolo e nervura, assim como divisões celulares anormais no mesofilo, que correspondem externamente a clorose na face adaxial e a manchas de coloração ferrugínea na face abaxial, chamadas de "bolhas de goma".

Malavolta (1993) demonstra que houve um controle parcial da doença com utilização de poda e adubação equilibrada com fertilizantes orgânicos e minerais, 
aplicando via foliar nitrato de potássio, molibdênio, boro, manganês e zinco. Observouse nesse estudo que as plantas doentes apresentaram baixos níveis foliares de potássio.

Machado (1993) relata que a bactéria Xylella fastidiosa está presente nos vasos xilemáticos de todas as variedades de tangerinas, mas os sintomas típicos que aparecem em variedades doces não se manifestam nas tangerinas. A microenxertia, aparentemente, elimina a bactéria dos tecidos, sendo uma técnica que pode ser utilizada para limpeza clonal em programas de multiplicação assexuada.

Almeida et al. (2001) estudaram a multiplicação e movimentação de Xylella fastidiosa em mudas de laranja doce inoculadas mecanicamente. Após oito semanas da inoculação surgiram os primeiros sintomas foliares, além de detectar a movimentação sistêmica da bactéria, a partir do ponto que recebeu a inoculação. A rápida colonização de Xylella fastidiosa e a expressão dos sintomas de CVC em plantas jovens indicam que esta técnica pode ser utilizada para estudos de Clorose Variegada dos Citros.

\subsection{Micorriza}

Estudos em raízes fossilizadas evidenciam que as micorrizas surgiram há 400 milhões de anos, período que coincide com o aparecimento das plantas terrestres, compreendidos entre 462 e 352 milhões de anos. Os fungos saprófitas surgiram há cerca de um milhão de anos, e tiveram um longo período de adaptação para estabelecerem relações mutualistas com as plantas. Para que isso ocorresse houve uma integração morfológica e funcional célula-célula, que são os requisitos básicos de uma relação simbiótica estável (Moreira et al., 2002).

As associações entre fungos e raízes foram observadas com detalhes no início do século XIX, mas só foram reconhecidas e tratadas cientificamente no final deste mesmo século, em 1885, quando Frank desenvolveu estudos científicos sobre a anatomia e ocorrência destas, especulou sobre os possíveis benefícios para a planta e empregou pela primeira vez o termo "micorriza" (mico = fungo e riza = raízes) (Moreira et al., 2002). Na maioria das raízes de plantas superiores são comuns a presença de micorrizas, que 
ocorre em 83\% das dicotiledôneas, em 79\% das monocotiledôneas e todas as gimnospermas são micorrizadas (Wilcox, 1991).

A micorrizacão é uma associação mutualística entre fungos e raízes, devido à interdependência e benefícios comuns, a planta recebe nutrientes via micélio do fungo e o fungo que é heterotrófico obtém fotoassimilados da planta hospedeira (Harley \& Smith, 1983).

Existem vários tipos de fungos micorrízicos, sendo que os mais comuns, são os endomicorrízicos ou vesículo-arbovascular (MVA), estando dispersos em vários tipos de plantas e ambientes, sendo os mais encontrados na rizosfera (Mosse, 1959). De acordo com Rhodes \& Gerdemann (1980), a hifa se ramifica de forma dicotômica dentro da raiz, onde forma os arbúsculos. As hifas internas e externas podem originar as vesículas, que aparentam ser estruturas de reservas do fungo. O trabalho de Whittingham \& Read (1982), demonstra que a infecção micorrízica forma estruturas de interconexão entre plantas jovens e adultas, através da qual ocorre transporte de nutrientes suficientes para promover respostas de crescimento. As plantas que possuem sistema radicular com número menor de pêlos são mais dependentes de fungos micorrízicos (Baylis, 1975).

Não ocorre micorrização em solos muito secos, salinos, alagados ou ainda em solos extremamente férteis ou de baixa fertilidade (Brundreté, 1991). Sobre todas as condições ambientais as crucíferas e quenopodiáceas não são hospedeiras de fungos micorrizicos (Harley and Harley 1987).

O suprimento mineral pode inibir ou aumentar a infecção radicular por micorrizas. Em solos com níveis extremamente baixos de fósforo a infecção por MVA também é baixa, o fósforo pode ser um fator limitante para o próprio desenvolvimento do fungo, com o suprimento de fósforo até atingir o nível ótimo a infecção aumenta, e pode diminuir a infecção, dependendo da espécie de micorriza. Altas adubações com fósforo diminuem a micorrização. Existe uma relação negativa entre infecção radicular por micorriza e suprimento de fósforo. Alto suprimento de nitrogênio também inibe a infecção micorrízica, particularmente quando combinado com fósforo alto e o nitrogênio, fornecido na forma de amônio (Marschner, 1995). 
Segundo Brechelt (1988), citado por Sieverding (1991), no processo de formação de mudas de tomate e caupi, a adição de esterco fresco no substrato, diminuiu a colonização de micorrizas, provavelmente devido à alta concentração de amônia.

Trabalhando com porta enxerto de citros, Nemec (1978) observou que a dependência de micorrizacão era inversamente proporcional à capacidade de produção de raízes. Dentre os nutrientes influenciados pela micorrizacão, o fósforo é o que mais responde a esse fenômeno, sendo encontrado em maiores concentrações em plantas micorrizadas do que em plantas não micorrizadas (Tinker, 1975).

Grandes quantidades de nutrientes no solo pode inibir a colonização micorrízica, altas concentrações de fósforo na planta pode torná-la imune à micorriza . O pH do solo também influencia a micorrizacão, quando o $\mathrm{pH}$ do solo é corrigido esta diminui, possivelmente pelo aumento da disponibilidade de fósforo. A associação fungo hospedeiro sofre mais interferência das interações do fungo com o solo do que com a planta (Mosse, 1972).

Existem muitos estudos de MVA em citros que foram realizados em viveiro, pelo fato da prática comum de esterilização do substrato para produção de mudas. Estes substratos esterilizados eram inoculados com MVA, sempre com respostas positivas no desenvolvimento e condição nutricional da planta, mas este mesmo nível de resposta não era conseguido quando a inoculação era efetuada em solo não esterilizado (Nemec \& Patterson, 1979, Kleinschmidt \& Gerdemann, 1972, Marx, 1971).

Menge et al (1982) estudaram vinte e seis tipos de solos de citros fumigado com brometo de metila. Estes solos foram inoculados com fungo MVA Glomus fasciculatum e cultivou porta enxertos de citros. Em vinte, dos vinte e seis solos, houve resposta positiva no desenvolvimento da planta, aumentando as concentrações de foliares de P, K e $\mathrm{Cu}$ e reduzindo as concentrações de $\mathrm{Mg}$ e $\mathrm{Na}$. A dependência de micorrizacão teve correlação positiva com o valor de $\mathrm{pH}$ do solo e foi inversamente proporcional aos teores de P, Zn, Mn, Cu, matéria orgânica e CTC do solo.

O’Bannon et al. (1979) observaram que seedlings de citros infectados por nematóide Tylenchulus semipenetrans, quando transplantados em solo com Glomus mosseae apresentam um maior desenvolvimento comparado com os seedlings não 
micorrizados. Davis \& Menge (1980) estudaram o efeito da micorrizacão e doses de fósforo na podridão radicular causada por Phythophtora em laranja Doce. Concluíram que a maior resistência das plantas inoculadas estaria ligada a maior capacidade de absorção de fósforo e outros nutrientes.

\subsection{DRIS (Diagnosis and Recommendation Integrated System)}

O Sistema Integrado de Diagnose e Recomendação (universalmente conhecido pela sigla DRIS) foi desenvolvido gradativamente a partir de 1956 quando foi estabelecido o método de Diagnose Fisiológica, o qual tinha por finalidade conhecer e estudar a influência de fatores externos (temperatura, pluviosidade, etc...) sobre a produção da seringueira (Beaufils, 1957, citado por Creste, 2000).

Segundo Malavolta et al. (1997), no método clássico a interpretação compara os resultados analíticos com parâmetros previamente tabelados. Esta técnica avalia o nutriente isoladamente, desprezando as interações existentes entre eles, quando mais de dois nutrientes se encontram abaixo do nível crítico, este método não permite avaliar qual foi o nutriente mais limitante à produção.

Já o método DRIS utiliza as razões entre as concentrações dos nutrientes na interpretação dos resultados de análise foliar e de solo. Este método não indica se determinado nutriente está em concentrações de toxidez ou deficiência, mas qual o elemento mais limitante e a ordem de limitação dos nutrientes. Comparando-se três métodos para recomendação de adubação em cana-de-açúcar observou-se que o método DRIS apresentou um aumento de 10 t/ha de cana e 1,7 t/ha de açúcar em relação ao método do nível crítico (Malavolta et al., 1997).

Pelas concentrações dos nutrientes nas folhas juntamente com os dados de produções, as observações são divididas em dois grupos: baixa produção (grupo A) e alta produção (grupo B). Utilizam-se critérios baseados em produções regionais, estaduais ou ainda o nível de 80-100\% da produção máxima obtida em experimentos de campo (Malavolta et al., 1997). 
Os índices nutricionais são originados a partir de um modelo matemático, que considera uma base de dados de produtividades obtidas e as relações entre os nutrientes na planta caracterizadas na forma de índices. O IBN (Índice de Balanço Nutricional), utilizado nesta pesquisa, é um índice agregado de desequilíbrio nutricional. Quanto maior for o seu valor, maior é o desequilíbrio nutricional e vice-versa (Creste, 2000).

\subsection{Variedades}

\subsubsection{Laranja Baia}

Foi descoberta no estado da Bahia e posteriormente foi distribuída para outros países, onde ficou conhecida no mundo como laranja com umbigo e sem sementes. A laranja Baia foi introduzida em Washington e posteriormente na Califórnia, onde foi rebatizada como Washington Navel. Os frutos são grandes, de cor laranja forte, esféricos, firmes, com casca ligeiramente rugosa, bolsas de óleo em nível, umbigo proeminente, polpa de cor laranja vivo, com suco abundante e nenhuma semente (Donadio et al., 1995).

\subsubsection{Laranja Pêra}

É conhecida como Pêra, Pêra Rio ou Pêra Coroa, apesar de ter passado longos períodos de menor interesse devido à tristeza, no entanto sua importância cresceu depois que foram obtidos clones pré-imunizados e graças à grande demanda da indústria. A origem desta variedade permanece obscura, existem várias hipóteses, mas sem comprovação clara, caracteristicamente é uma variedade que apresenta altos teores de suco sendo reputada como uma das melhores. Os frutos são pequenos, cor laranja, casca quase abundante, e suco ligeiramente ácido (São Paulo) ou doce (Rio), 3 a 4 sementes por fruto e árvores de porte médio. Apresenta boa compatibilidade com porta-enxertos comerciais, exceto Trifoliata e seus híbridos (Donadio et al., 1995). 


\subsubsection{Laranja Natal}

De origem desconhecida, admite-se que seja uma mutação ou clone de laranja Valência, com a qual é muito similar. Tornou-se a variedade preferida pelos citricultores, depois da laranja Pêra, devido a excelente produção e qualidade de seus frutos. As folhas são menores quando comparadas com Pêra e Valência, o que tem sido uma característica para diferenciação da variedade (Donadio et al., 1995).

\subsubsection{Laranja Escape}

O nome “Escape” é dado às plantas que no meio de um pomar com alto índice de CVC, permanecem assintomáticas, apresentando todas as características de uma planta sadia (Figura 1). Na fazenda São Domingos no município de Novais - estado de São Paulo, existe um talhão com doze mil plantas que apresenta alto índice de CVC em cem por cento das plantas, exceto algumas plantas que se destacam como saudáveis, dentro deste talhão. As características morfológicas desta planta são semelhantes às da laranja Natal e Valência, com um diferencial que é a presença de umbigo em alguns frutos, sendo que os demais frutos não apresentam esta característica. O proprietário da fazenda multiplicou este material, que está com quatro anos e não apresentam sintomas de CVC, o que aparentemente indica que esta característica é transmitida pela reprodução vegetativa.

Pelas características morfológicas da planta e as informações da origem do material, provavelmente seja uma mutação natural de uma laranja Natal, Valência ou ainda laranja Baia. 


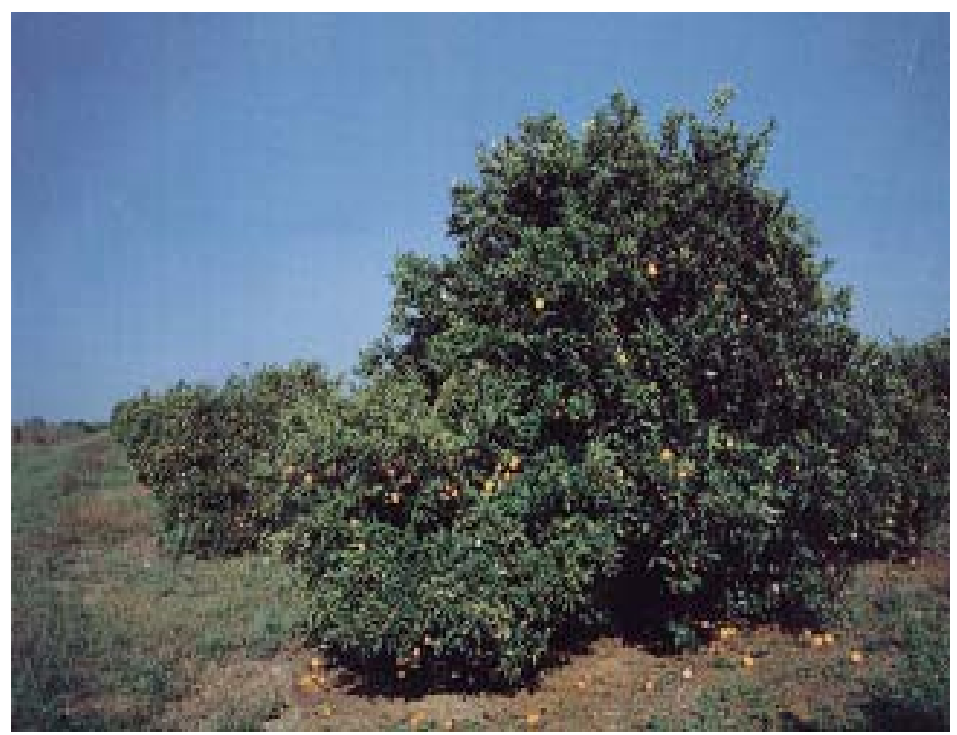

Figura 1 - Planta "Escape” sem sintomas de CVC, rodeada de plantas doentes por CVC 


\section{MATERIAL E MÉTODOS}

\subsection{Material}

\subsubsection{Local do experimento}

O experimento foi conduzido em telado comercial para produção de mudas cítricas, no sitio Jardim, município de Novais - SP (Figura 2), que está na região norte do estado de São Paulo a $540 \mathrm{~m}$ de altitude, $48^{\circ} 55^{\prime}$ de longitude a oeste de Greenwich e $21^{\circ} 00^{\prime}$ de latitude sul. A temperatura média da região é de $22,7^{\circ} \mathrm{C}$, sendo a máxima de $30^{\circ} \mathrm{C}$ e a mínima de $12^{\circ} \mathrm{C}$ (Pedro Junior et al. ,1994) .

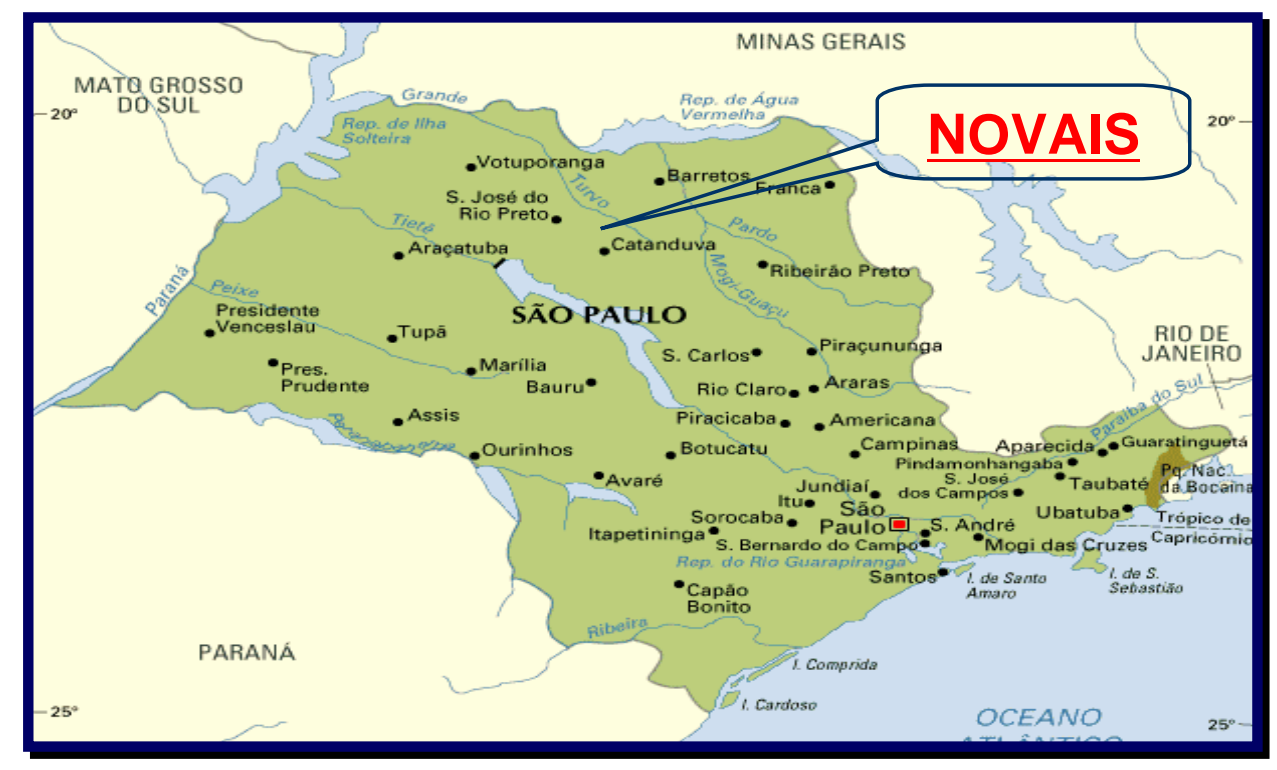

Figura 2 - Localização geográfica do local onde foi conduzido o experimento 


\subsubsection{Casa de vegetação}

A casa de vegetação (Figura 3) era protegida por uma tela de malha com abertura 0,64 mm, para impedir a entrada de insetos transmissores de Xylella fastidiosa (cigarrinhas). $\mathrm{O}$ acesso era feito através de uma antecâmara, com presença de pedilúvio para desinfestação e desinfecção de calçados. As mudas ficavam isoladas do solo através de uma camada de brita, com $10 \mathrm{~cm}$ espessura. As plantas permaneciam suspensas, sobre blocos de concreto, impedindo qualquer contaminação de patógenos de solo. $\mathrm{O}$ interior da estufa era livre de plantas daninhas, e os restos de materiais vegetais, oriundos de desbrotas, eram transportados para fora e incinerados.

A casa de vegetação estava a trinta metros de distância de planta cítrica. A área era drenada de tal forma que impedia entrada de água de enxurradas, além de haver uma mureta de alvenaria com quarenta centímetros de altura para proteger ainda mais o ambiente.

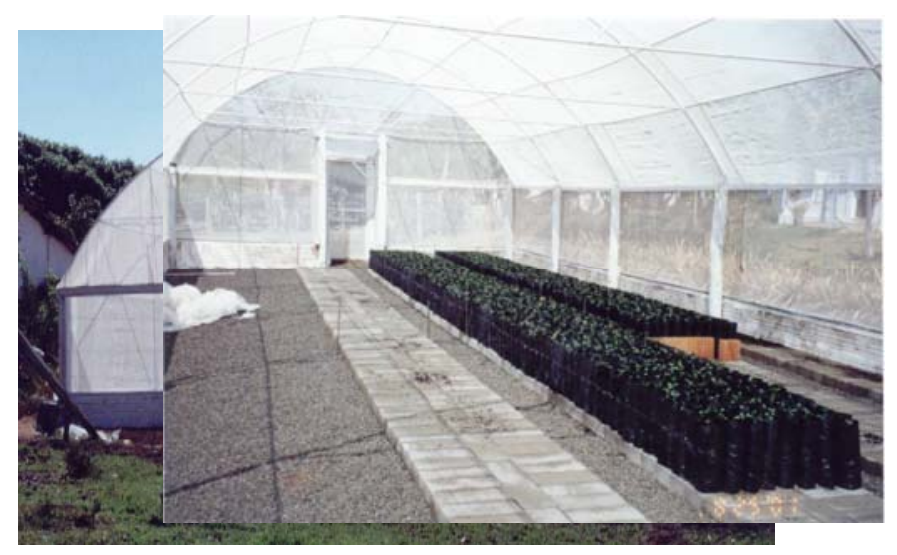

Figura 3 - Casa de vegetação onde foi conduzido o experimento

\subsubsection{Unidades experimentais - vasos}

Os vasos (Figura 4) eram de polietileno preto, com altura de quarenta centímetros e diâmetro de doze centímetros, totalizando um volume de 4,5 litros por vaso. Os vasos possuíam orifícios laterais para que ocorresse uma boa drenagem. Na base havia um 
orifício maior, por onde a raiz principal saía e ao entrar em contato com o ar cessava o crescimento, havendo uma poda natural do sistema radicular. Por este orifício era possível observar o teor de umidade do substrato, por onde era feito o controle da irrigação.

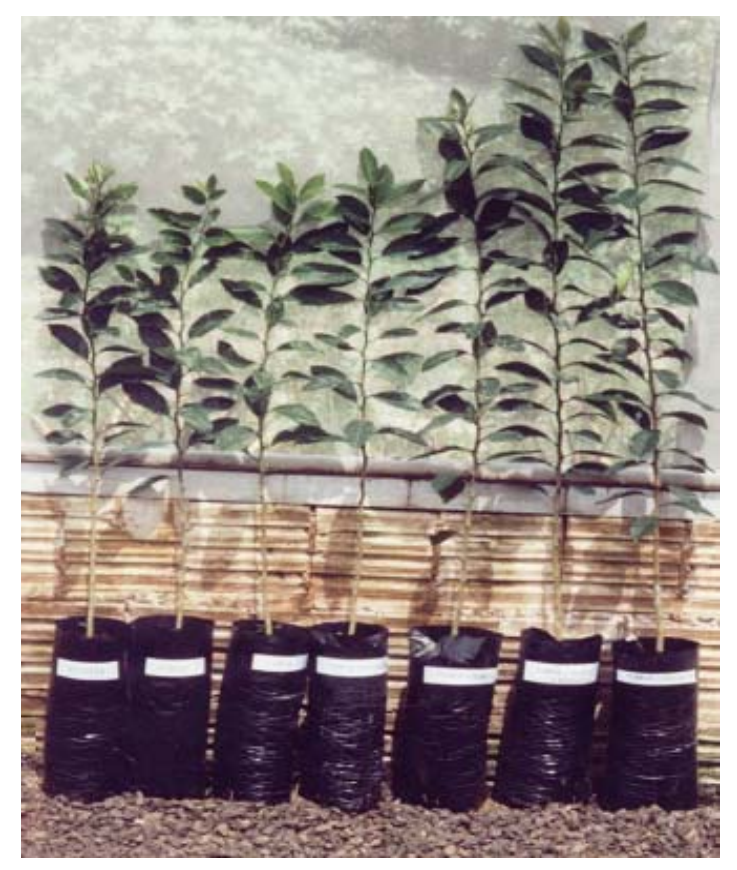

Figura 4 - Vasos de polietileno, onde foram produzidas as mudas

\subsubsection{Plantas}

O porta enxerto utilizado foi o limoeiro 'Cravo' (Citrus limonia Osbeck cv. Cravo). Os porta enxertos foram produzidos em Viveiro Certificado para Produção de Mudas Cítricas, localizado no município de Cajobi-SP. As variedades copas empregadas foram laranja doce (Citrus sinensis (L.) Osbeck), das variedades Baia, Natal e Pêra Rio. Outra variedade empregada foi a laranja Doce, denominada planta "Escape”. Os materiais propagativos das variedades Baia, Natal e Pêra vieram do Centro de Citricultura Sylvio Moreira de Cordeirópolis - SP. Enquanto que o material propagativo da planta "Escape” foi proveniente da Fazenda São Domingos, no município de NovaisSP. 


\subsubsection{Substrato}

O experimento utilizou o substrato comercial da marca Plantmax obtido da empresa Eucatex e o vermicomposto de minhoca (matéria prima a base de torta de filtro), sendo que não houve esterilização dos substratos antes do plantio. As análises químicas se encontram na Tabela 1.

Tabela 1. Análise química dos substratos comercial e vermicomposto (na M.S.)

\begin{tabular}{|c|c|c|}
\hline DETERMINAÇÕES & VERMICOMPOSTO & SUBSTRATO COMERCIAL \\
\hline Nitrogênio - N (g kg ${ }^{-1}$ ) & 16,4 & 16,5 \\
\hline Fósforo $-\mathrm{P}_{2} \mathrm{O}_{5}\left(\mathrm{~g} \mathrm{~kg}^{-1}\right)$ & 11 & 8,6 \\
\hline Potássio - $\mathrm{K}_{2} \mathrm{O}\left(\mathrm{mg} \mathrm{kg}^{-1}\right)$ & 955 & 2600 \\
\hline Cálcio - Ca (g kg-1) & 10,3 & 8,5 \\
\hline Magnésio - Mg (g kg $\left.{ }^{-1}\right)$ & 1,7 & 13,5 \\
\hline Enxofre - S ( $\left.\mathrm{g} \mathrm{kg}^{-1}\right)$ & 4 & 8,2 \\
\hline Ferro - Fe $\left(\mathrm{g} \mathrm{kg}^{-1}\right)$ & 24,5 & 9,2 \\
\hline Manganês - Mn (mg kg-1) & 445 & 170 \\
\hline Cobre - Cu (mg kg $\left.{ }^{-1}\right)$ & 192 & 23 \\
\hline Zinco - Zn (mg kg $\left.{ }^{-1}\right)$ & 254 & 54 \\
\hline Boro - B (mg kg $\left.{ }^{-1}\right)$ & 240 & 260 \\
\hline Sódio - Na (mg kg $\left.{ }^{-1}\right)$ & 435 & 390 \\
\hline Matéria Orgânica (g kg-1) & 192,7 & 651,7 \\
\hline Cinzas $\left(\mathrm{g} \mathrm{kg}^{-1}\right)$ & 807,3 & 348,3 \\
\hline Umidade ( $\mathrm{g} \mathrm{kg}^{-1}$ ) & 243,8 & 514,5 \\
\hline $\mathrm{pH}$ & 6,2 & 4,9 \\
\hline Relação C/N & $6 / 1$ & $22 / 1$ \\
\hline
\end{tabular}

Análise realizada no laboratório Unithal - Campinas - SP, em 20/08/2000 


\subsubsection{Irrigação}

As mudas eram irrigadas manualmente através de mangueira com um chuveiro na extremidade, até atingir a capacidade de campo do substrato e retornava a irrigação quando o fundo do vaso começava a secar. A água era originada de poço artesiano, com noventa metros de profundidade e a análise química se encontra na Tabela 2.

Tabela 2. Análise química da água de irrigação

\begin{tabular}{ccc}
\hline Parâmetro & Valor & Unidade \\
\hline $\mathrm{pH}$ & 6,1 & - \\
Condutividade elétrica & 165 & $\mathrm{~ms} \mathrm{~s}^{-1}$ \\
$\mathrm{SO}_{4}^{-2}$ & $<1$ & $\mathrm{mg} \mathrm{L}^{-1}$ \\
$\mathrm{Ca}$ & 21 & $\mathrm{mg} \mathrm{L}^{-1}$ \\
$\mathrm{Mg}$ & 4,5 & $\mathrm{mg} \mathrm{L}^{-1}$ \\
$\mathrm{Na}$ & 3,0 & $\mathrm{mg} \mathrm{L}^{-1}$ \\
$\mathrm{~K}$ & 3,7 & $\mathrm{mg} \mathrm{L}^{-1}$ \\
$\mathrm{Al}$ & $<0,1$ & $\mathrm{mg} \mathrm{L}^{-1}$ \\
$\mathrm{P}$ & $<0,4$ & $\mathrm{mg} \mathrm{L}^{-1}$ \\
$\mathrm{Si}$ & 17 & $\mathrm{mg} \mathrm{L}^{-1}$ \\
$\mathrm{Fe}$ & $<0,02$ & $\mathrm{mg} \mathrm{L}^{-1}$ \\
$\mathrm{Cu}$ & $<0,02$ & $\mathrm{mg} \mathrm{L}^{-1}$ \\
$\mathrm{Zn}$ & $<0,01$ & $\mathrm{mg} \mathrm{L}^{-1}$ \\
$\mathrm{Mn}$ & $<0,03$ & $\mathrm{mg} \mathrm{L}^{-1}$ \\
$\mathrm{Cd}$ & $<0,002$ & $\mathrm{mg} \mathrm{L}^{-1}$ \\
$\mathrm{Cr}$ & 0,02 & $\mathrm{mg} \mathrm{L}^{-1}$ \\
$\mathrm{Ni}$ & 0,17 & $\mathrm{mg} \mathrm{L}^{-1}$ \\
$\mathrm{Sr}$ & 0,17 & $\mathrm{mg} \mathrm{L}^{-1}$ \\
$\mathrm{~B}$ & $<0,003$ & $\mathrm{mg} \mathrm{L}^{-1}$ \\
$\mathrm{~Pb}$ & $<0,05$ & $\mathrm{mg} \mathrm{L}^{-1}$ \\
$\mathrm{Ba}$ & 0,3 &
\end{tabular}




\subsection{Metodologia}

\subsubsection{Tratamentos}

Os tratamentos envolveram três fatores: substratos (3), variedades (4) e inoculação (2). Os substratos considerados foram: (a) 100\% vermicomposto; (b) 100 \% substrato comercial; e (c) 50\%-50\% (em volume) de vermicomposto e substrato comercial. As variedades incluíram: (a) Baia; (b) Pêra; (c) Natal; e (d) Escape. Finalmente, a inoculação envolveu 2 níveis: (a) inoculado; e, (b) não inoculado com Xylella fastidiosa, perfazendo 24 tratamentos (variedades x substratos x inoculação), cuja descrição está apresentada na Tabela 3. Cada tratamento contou com 6 repetições, totalizando 144 mudas no experimento como um todo (Figura 5). O posicionamento das mudas na bancada foi determinado por sorteio. Cada uma das mudas (parcela experimental) foi avaliada quanto aos seguintes aspectos: (a) diâmetro do caule $(10 \mathrm{~cm}$ do colo); (b) altura da planta; (c) peso da matéria seca da parte aérea; (d) peso da matéria seca do sistema radicular; (e) taxa de micorrização, (f) macronutrientes e (g) micronutrientes. Na Tabela 4, encontram-se os procedimentos analíticos de cada mensuração. 


\begin{tabular}{|c|c|c|c|c|c|c|c|}
\hline \multicolumn{8}{|l|}{ Bloco 1} \\
\hline $\mathrm{T} 15$ & $\mathrm{~T} 15$ & $\mathrm{~T} 20$ & $\mathrm{~T} 20$ & T06 & T06 & $\mathrm{T} 18$ & $\mathrm{~T} 18$ \\
\hline T05 & T05 & T19 & T19 & T22 & $\mathrm{T} 22$ & T03 & $\mathrm{T} 03$ \\
\hline T04 & T04 & T07 & T07 & T24 & $\mathrm{T} 24$ & $\mathrm{~T} 23$ & T23 \\
\hline T02 & T02 & $\mathrm{T} 13$ & $\mathrm{~T} 13$ & T08 & T08 & $\mathrm{T} 01$ & $\mathrm{~T} 01$ \\
\hline $\mathrm{T} 11$ & $\mathrm{~T} 11$ & $\mathrm{~T} 21$ & $\mathrm{~T} 21$ & T09 & T09 & $\mathrm{T} 14$ & $\mathrm{~T} 14$ \\
\hline T16 & T16 & $\mathrm{T} 17$ & T17 & T10 & $\mathrm{T} 10$ & $\mathrm{~T} 12$ & $\mathrm{~T} 12$ \\
\hline \multicolumn{8}{|c|}{ 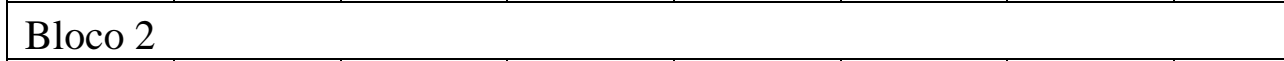 } \\
\hline $\mathrm{T} 15$ & T15 & $\mathrm{T} 20$ & $\mathrm{~T} 20$ & T06 & T06 & T18 & $\mathrm{T} 18$ \\
\hline T05 & T05 & T19 & T19 & $\mathrm{T} 22$ & $\mathrm{~T} 22$ & T03 & T03 \\
\hline T04 & T04 & T07 & T07 & $\mathrm{T} 24$ & $\mathrm{~T} 24$ & $\mathrm{~T} 23$ & $\mathrm{~T} 23$ \\
\hline T02 & T02 & $\mathrm{T} 13$ & T13 & T08 & T08 & T01 & T01 \\
\hline T11 & T11 & $\mathrm{T} 21$ & $\mathrm{~T} 21$ & T09 & T09 & T14 & $\mathrm{T} 14$ \\
\hline $\mathrm{T} 16$ & T16 & $\mathrm{T} 17$ & T17 & $\mathrm{T} 10$ & $\mathrm{~T} 10$ & $\mathrm{~T} 12$ & $\mathrm{~T} 12$ \\
\hline \multicolumn{8}{|c|}{ Bloco 3} \\
\hline T15 & $\mathrm{T} 15$ & $\mathrm{~T} 20$ & $\mathrm{~T} 20$ & T06 & T06 & $\mathrm{T} 18$ & $\mathrm{~T} 18$ \\
\hline T05 & T05 & T19 & T19 & $\mathrm{T} 22$ & T22 & T03 & T03 \\
\hline T04 & T04 & T07 & T07 & T24 & $\mathrm{T} 24$ & $\mathrm{~T} 23$ & T23 \\
\hline T02 & T02 & $\mathrm{T} 13$ & $\mathrm{~T} 13$ & T08 & T08 & T01 & $\mathrm{T} 01$ \\
\hline T11 & T11 & $\mathrm{T} 21$ & T21 & T09 & T09 & T14 & $\mathrm{T} 14$ \\
\hline T16 & T16 & T17 & T17 & T10 & T10 & $\mathrm{T} 12$ & T12 \\
\hline
\end{tabular}

Figura 5 - Esboço do croqui do experimento 
Tabela 3. Tratamentos realizados no experimento em casa-de-vegetação

\begin{tabular}{|c|c|c|c|}
\hline TRATAMENTO & VARIEDADE & SUBSTRATO & INOCULAÇÃO \\
\hline $\mathrm{T} 1$ & Baia & Vermicomposto & Sim \\
\hline $\mathrm{T} 2$ & Baia & Vermicomposto & Não \\
\hline Т3 & Baia & Subst. Comercial & Sim \\
\hline $\mathrm{T} 4$ & Baia & Subst. Comercial & Não \\
\hline T5 & Baia & Vermicomposto + Subst. Comercial & Sim \\
\hline T6 & Baia & Vermicomposto + Subst. Comercial & Não \\
\hline T7 & Escape & Vermicomposto & Sim \\
\hline T8 & Escape & Vermicomposto & Não \\
\hline T9 & Escape & Subst. Comercial & Sim \\
\hline $\mathrm{T} 10$ & Escape & Subst. Comercial & Não \\
\hline $\mathrm{T} 11$ & Escape & Vermicomposto + Subst. Comercial & Sim \\
\hline $\mathrm{T} 12$ & Escape & Vermicomposto + Subst. Comercial & Não \\
\hline $\mathrm{T} 13$ & Natal & Vermicomposto & Sim \\
\hline $\mathrm{T} 14$ & Natal & Vermicomposto & Não \\
\hline T15 & Natal & Subst. Comercial & Sim \\
\hline T16 & Natal & Subst. Comercial & Não \\
\hline $\mathrm{T} 17$ & Natal & Vermicomposto + Subst. Comercial & Sim \\
\hline T18 & Natal & Vermicomposto + Subst. Comercial & Não \\
\hline T19 & Pêra & Vermicomposto & Sim \\
\hline $\mathrm{T} 20$ & Pêra & Vermicomposto & Não \\
\hline $\mathrm{T} 21$ & Pêra & Subst. Comercial & Sim \\
\hline $\mathrm{T} 22$ & Pêra & Subst. Comercial & Não \\
\hline $\mathrm{T} 23$ & Pêra & Vermicomposto + Subst. Comercial & Sim \\
\hline T24 & Pêra & Vermicomposto + Subst. Comercial & Não \\
\hline
\end{tabular}

Subst. Comercial $=$ Substrato Comercial Inoculação $=$ Inoculação com Xylella fastidiosa - inoculado (Sim) e não inoculado (Não). A mistura do Vermicomposto e Subst.Comercial, foi feita com relação 1:1, relação volume/volume. 
Tabela 4. Procedimentos analíticos de cada mensuração

\begin{tabular}{|c|c|}
\hline Mensuração & Procedimento Utilizado \\
\hline Diâmetro do caule (10 cm do colo) & Paquímetro digital \\
\hline Altura da planta & Régua \\
\hline Peso da matéria seca da parte aérea & Balança digital \\
\hline Peso da matéria seca do sistema radicular & Balança digital \\
\hline Taxa de micorrização & Coloração (Lopes et al., 1983). \\
\hline Índice de Balanço Nutricional - IBN & DRIS - Citros, Creste \& Nakagawa (2000) \\
\hline $\mathrm{N}$ (foliar) & $\begin{array}{c}\text { Digestão sulfúrica e determinação pelo método semi- } \\
\text { micro Kjeldahl (Malavolta et al., 1997). }\end{array}$ \\
\hline$P$ (foliar) & $\begin{array}{l}\text { Digestão nítrico-perclórica e determinação por } \\
\text { colorimetria (Malavolta et al., 1997). }\end{array}$ \\
\hline K (foliar) & $\begin{array}{l}\text { Digestão nítrico-perclórica e determinação por } \\
\text { fotometria de chama (Malavolta et al., 1997). }\end{array}$ \\
\hline Ca, Mg, Cu, Fe, Mn e Zn (foliar) & $\begin{array}{l}\text { Extração nítrico-perclórica e determinação por } \\
\text { espectrometria de absorção (Malavolta et al., 1997). }\end{array}$ \\
\hline S (foliar) & $\begin{array}{l}\text { Digestão nítrico-perclórica e determinação por tur- } \\
\text { bidimetria do sulfato de bário (Malavolta et al., 1997). }\end{array}$ \\
\hline B (foliar) & $\begin{array}{l}\text { Digestão seca e determinação por colorimetria da } \\
\text { azometina-H (Malavolta et al., 1997). }\end{array}$ \\
\hline Xylella fastidiosa & PCR-Molecular (Rodrigues et al., 2003) \\
\hline
\end{tabular}

\subsubsection{Instalação e condução do experimento}

O experimento iniciou-se em Novembro de 2001, com o transplantio do portaenxerto de limoeiro Cravo e três meses após, foi realizada a enxertia (Fevereiro/2002), utilizando o método de “T” invertido e após a enxertia os porta enxertos foram dobrados 
para forçar a brotação do enxerto. A região da enxertia ficou envolvida com fita plástica durante quinze dias, até que ocorresse uma cicatrização entre a borbulha e o porta enxerto.

Noventa dias após a enxertia (Maio/2002), as mudas foram inoculadas mecanicamente com Xylella fastidiosa, nas regiões tenras do ponteiro da planta. O método de inoculação empregado foi o mesmo utilizado por Almeida et al. (2001), que consiste na inoculação mecânica, através da introdução de objeto pontiagudo (alfinete) contaminado por Xylella fastidiosa.

Segundo informações pessoais do Professor Doutor J. R. S. Lopes, do Departamento de Entomologia, Fitopatologia e Zoologia Agrícola da ESALQ-USP, a técnica acima citada tem eficiência de 50 a 80\% em plantas jovens, sendo que à medida que as plantas envelhecem, diminui-se a eficiência. A dose mínima para ser eficaz é de $10^{4}$ a $10^{5}$ unidades formadoras de colônia/grama de tecido.

As avaliações foram efetuadas em fevereiro de 2003 e os itens analisados foram os seguintes: altura da planta, diâmetro do caule a $10 \mathrm{~cm}$ de altura do colo, peso da matéria seca do sistema radicular, peso da matéria seca parte aérea, taxa de micorrizacão, análise química foliar e presença de Xylella fastidiosa.

Para avaliação de micorrização, foi utilizada a "Técnica de centrifugação de frações de peneiramento do solo” (Lopes et al., 1983).

A adubação no substrato foi feita com gesso agrícola (1g/vaso), map (2g/vaso) e nitrato de potássio (2g/vaso), a cada vinte dias. A adubação iniciou logo após o pegamento do porta-enxerto e prolongou até cento e vinte dias depois da enxertia. Após esta data, as mudas não foram mais adubadas.

As plantas também receberam adubação foliar a cada vinte dias, com uma solução de nitrato de potássio (0,5\%), sulfato de zinco $(0,05 \%)$, sulfato de manganês (0,05\%), sulfato de magnésio (0,05\%) e sulfato ferroso (0,025\%). O cronograma da adubação foliar foi o mesmo da adubação do substrato. 


\subsubsection{Procedimentos gerais utilizados na análise estatística}

A análise estatística foi desenvolvida com o intuito de explorar exaustivamente as relações multivariadas existentes entre muitas mensurações e os fatores considerados no experimento. Inicialmente, foi utilizado um conjunto procedimentos associados à chamada EDA (Exploratory Data Analysis), desenvolvida pelo eminente estatístico John Tukey (Tukey, 1977). Essa técnica tem o objetivo de explorar exaustivamente os dados existentes, com o auxílio de gráficos apropriados, que evidenciam a variabilidade existente, objetivando a identificação e descrição de possíveis padrões e associações estatísticas e suas magnitudes. A técnica evita a utilização de pressuposições fortes $a$ priori, a respeito da estrutura dos dados. Facilita a apresentação e síntese de conjuntos complexos de dados, destacando possíveis resultados experimentais. O uso da EDA de uma forma mais ampla tem sido facilitado ao longo da última década, com sua implementação nos programas modernos de análise estatística.

A etapa exploratória da análise contou com a utilização de: (a) diagramas de Tuckey, comparando os dados dos diferentes tratamentos; (b) Coplots; e, (c) Diagramas de dispersão das mensurações, com observações identificadas por tratamento. A descrição dessas técnicas é apresentada em livros texto como Venables e Ripley (2002).

Num segundo momento, foi utilizada a análise de regressão múltipla e análise de variância convencional (Venables e Ripley, 2002). Para quantificação e teste estatístico dos efeitos observados na primeira etapa da análise (EDA). Todas as análises foram realizadas dentro do software estatístico R (Ihaka e Gentleman, 1996), versão 1.7.1.

\subsubsection{DRIS}

Para verificar o estado nutricional das plantas nos diversos tratamentos, foi feita análise de macro e micro nutrientes no tecido vegetal das folhas e posteriormente aplicado a ferramenta DRIS para avaliar o equilíbrio entre os nutrientes analisados. 


\section{RESULTADOS E DISCUSSÃO}

A primeira seção apresenta uma visualização geral dos resultados principais, utilizando para isso gráficos de Tuckey que caracterizam graficamente os impactos dos diferentes fatores considerados (substratos, variedades e inoculação) sobre variáveis biométricas das mudas. A segunda seção apresenta diagramas de dispersão e regressões que caracterizam o comportamento de variáveis biométricas mensuradas, com observações indicando o tratamento considerado. O Anexo A2 apresenta gráficos (denominados usualmente de coplots) por variedade, caracterizando o comportamento dos teores foliares 2 a 2, de macro e micro nutrientes, com observações indicando o

tratamento considerado. Finalmente, é apresentada uma síntese contendo a significância estatística dos efeitos dos fatores considerados, sobre as variáveis biométricas mensuradas, obtidas a partir de uma análise de variância.

\subsection{Caracterização geral dos resultados}

\subsubsection{Impacto no peso da matéria seca da parte aérea (pspa)}

A Figura 6 apresenta diagramas de Tukey contendo o peso da matéria seca da parte aérea obtida no experimento.

Cada diagrama corresponde a um tratamento em particular, associado a um substrato, um variedade e se foi inoculado ou não com a Xylella fastidiosa. A organização dos diagramas foi definida de forma a facilitar a comparação dos 3 substratos considerados, em cada variedade. Os diagramas da coluna da esquerda correspondem à situação em que as mudas não foram inoculadas; nos da coluna da direita as mudas foram inoculadas. Cada diagrama é composto por um retângulo central, 
2 barras extremas e um ponto. O ponto corresponde à mediana dos dados nas repetições. O retângulo central indica que 50\% dos dados foram observados nessa região. As barras mais extremas indicam o máximo e o mínimo valores observados. Círculos abertos indicam possíveis outliers.

A Figura 6 sugere que o peso da matéria seca da parte aérea das mudas nos tratamentos que utilizaram vermicomposto (mistura 50\% ou 100\%) foi distintamente superior ao observado nas mudas que utilizaram somente o substrato comercial. No caso da variedade Pêra inoculada, por exemplo, a mediana do peso da matéria seca da parte aérea das mudas que utilizaram substrato comercial foi próxima de $40 \mathrm{~g}$ enquanto as que utilizaram substrato vermicomposto e mistura tiveram a mediana do peso próxima de 120g. Essa observação é verificada para todos os variedades e situações quanto à inoculação. Quando comparados, contudo, os pesos observados nos tratamentos vermicomposto (100\%) e mistura (50\%), apresentaram-se mais próximos, com alguma pequena superioridade aparente sugerida em alguns casos, como na variedade Baia (com e sem inoculação) e na variedade Natal (sem inoculação). Os efeitos dos variedades e da inoculação são menos aparentes na figura.

A análise de variância, cujos resultados são sumarizados na Tabela 5, apresentada na seção 4.3, indica significância estatística para os efeitos associados ao fator substrato (nível de 0,1\%) e para a interação substrato-variedade (nível de 5\%). 


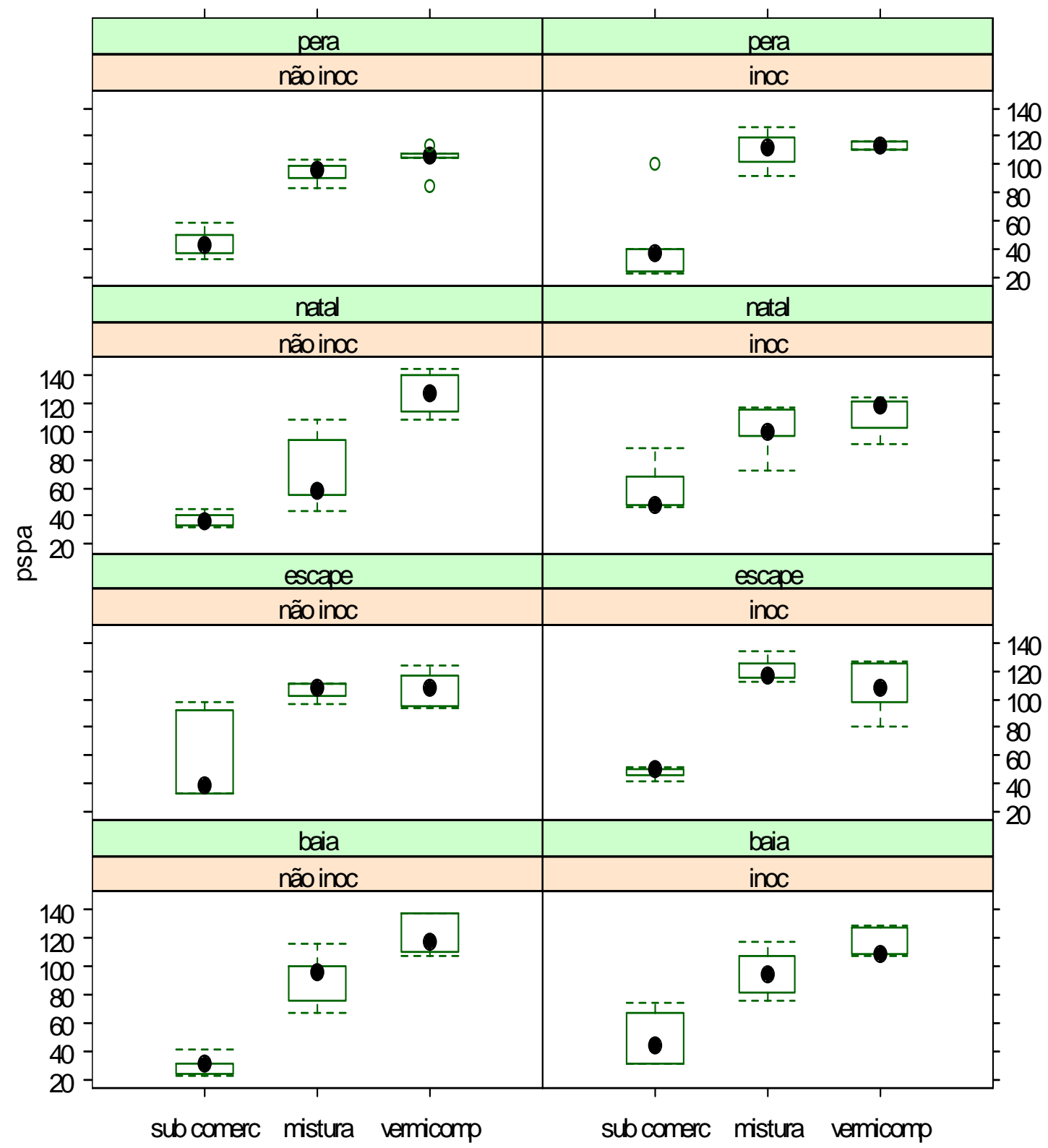

Figura 6 - Diagrama de Tuckey do peso da matéria seca da parte aérea (pspa) em gramas, por substrato, variedade e tipo de inoculação 


\subsubsection{Impacto no peso da matéria seca da parte radicular (pssr)}

A Figura 7 apresenta diagramas de Tukey contendo o peso da matéria seca do sistema radicular obtida no experimento.

A Figura 7 sugere que o peso da matéria seca do sistema radicular das mudas nos tratamentos que utilizaram vermicomposto (mistura 50\% ou 100\%) foi distintamente superior ao observado nas mudas que utilizaram somente o substrato comercial. No caso da variedade Pêra inoculada, por exemplo, a mediana do peso da matéria seca do sistema radicular das mudas que utilizaram substrato comercial foi próxima de $40 \mathrm{~g}$ enquanto as que utilizaram substrato vermicomposto e mistura tiveram a mediana do peso próxima de 60g. Essa tendência é verificada para todos os variedades e situações quanto à inoculação, com menor evidência para os variedades Pêra e Natal não inoculados. Quando comparados, contudo, os pesos observados nos tratamentos vermicomposto (100\%) e mistura (50\%), apresentaram-se mais próximos, com alguma pequena superioridade aparente sugerida em alguns casos, como a variedade Natal não inoculado. Os efeitos dos variedades e da inoculação são menos aparentes na figura.

A análise de variância, cujos resultados são sumarizados na Tabela 5, apresentada na seção 4.3, indica significância estatística para os efeitos associados aos fatores substrato (nível de 0,1\%), variedade (nível de 5\%), para a interação variedadesubstrato (nível de 1\%), para a interação variedade-inoculação (nível de 5\%) e para a interação inoculação-substrato (nível de 5\%). 


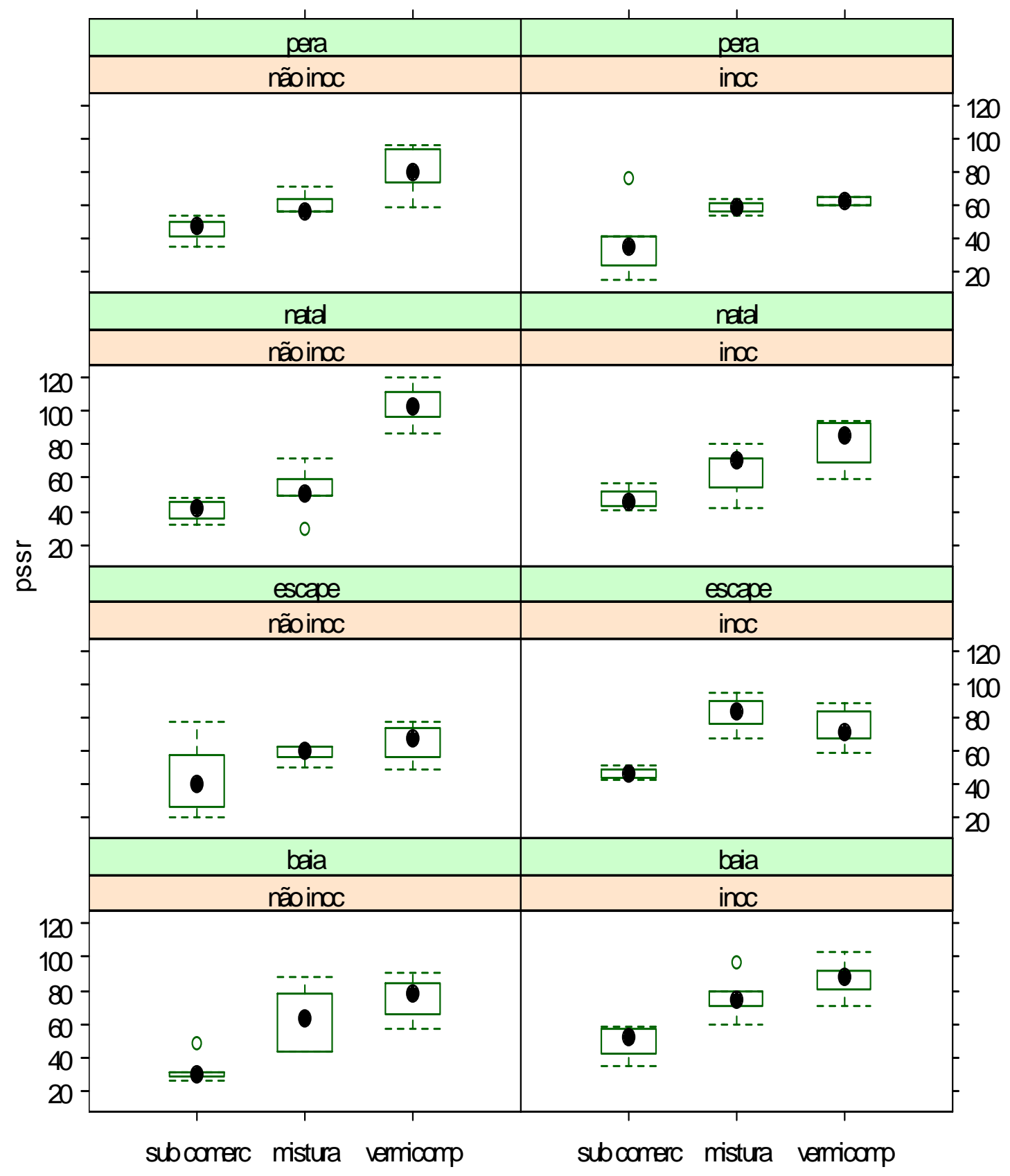

Figura 7 - Diagrama de Tukey da matéria seca do sistema radicular (pssr) em gramas, por substrato, variedade e tipo de inoculação 


\subsubsection{Impacto no diâmetro do caule a $10 \mathrm{~cm}$ do colo (d)}

A Figura 8 apresenta diagramas de Tukey contendo o diâmetro do caule a $10 \mathrm{~cm}$ do colo obtido no experimento.

A Figura 8 sugere que o diâmetro do caule a $10 \mathrm{~cm}$ do colo das mudas nos tratamentos que utilizaram vermicomposto (mistura 50\% ou 100\%) foi distintamente superior ao observado nas mudas que utilizaram somente o substrato comercial, exceto na variedade Natal inoculada e não inoculada. No caso da variedade Pêra inoculada, por exemplo, a mediana do diâmetro do caule a $10 \mathrm{~cm}$ do colo das mudas que utilizaram substrato comercial foi próxima de $11 \mathrm{~mm}$ enquanto as que utilizaram substrato vermicomposto e mistura tiveram a mediana do diâmetro próxima de $17 \mathrm{~mm}$ e $15 \mathrm{~mm}$ respectivamente. Essa tendência é verificada para todos os variedades e situações quanto à inoculação, com menor evidência para a variedade Natal inoculada e não inoculados. Quando comparados, contudo, os diâmetros observados nos tratamentos vermicomposto (100\%) e mistura (50\%), apresentaram-se mais próximos. Os efeitos dos variedades e da inoculação são menos aparentes na figura.

A análise de variância, cujos resultados são sumarizados na Tabela 5, apresentada na seção 4.3, indica significância estatística para os efeitos associados ao fator substrato (nível de 0,1\%) e para a interação substrato-variedade (nível de 5\%). 


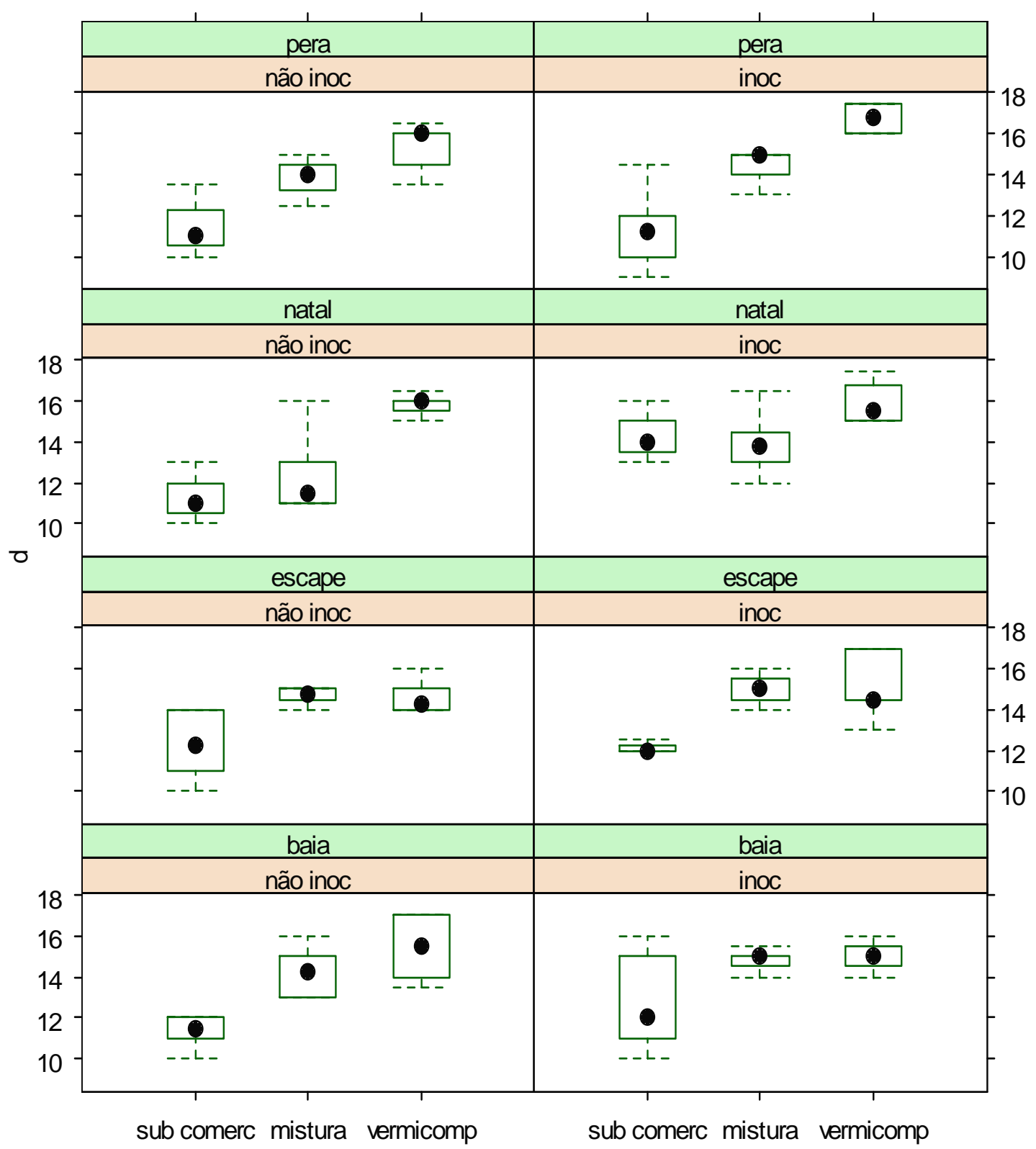

Figura 8 - Diagrama de Tukey do diâmetro do caule a $10 \mathrm{~cm}$ do colo em milímetros, por substrato, variedade e tipo de inoculação 


\subsubsection{Impacto na altura da planta (a)}

A Figura 9 apresenta diagramas de Tukey contendo altura da planta obtida no experimento.

A Figura 9 sugere que a altura das mudas nos tratamentos que utilizaram vermicomposto (mistura 50\% ou 100\%) foi distintamente superior ao observado nas mudas que utilizaram somente o substrato comercial. No caso da variedade Pêra inoculada, por exemplo, a mediana da altura das mudas que utilizaram substrato comercial foi próxima de $100 \mathrm{~cm}$ enquanto as que utilizaram substrato vermicomposto e mistura tiveram a mediana da altura igual a $130 \mathrm{~cm}$. A análise de variância, cujos resultados são sumarizados na Tabela 5, apresentada na seção 4.3, indica significância estatística para os efeitos associados ao fator substrato (nível de 0,1\%). 


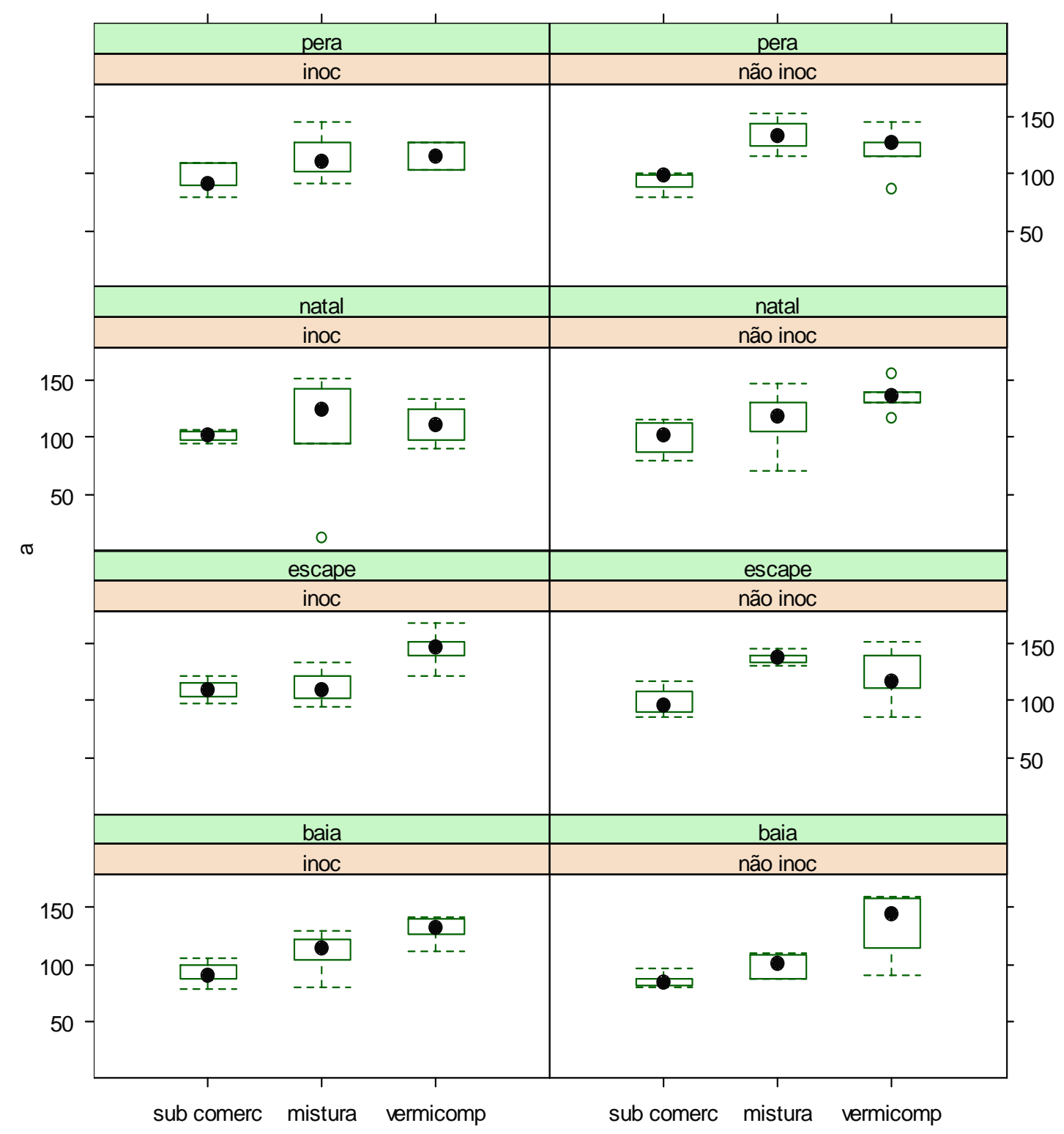

Figura 9 - Diagrama de Tukey da altura da planta em centímetros, por substrato, variedade e tipo de inoculação 


\subsubsection{Impacto na micorrização (mva)}

A Figura 10 apresenta diagramas de Tukey contendo a micorrização obtida no experimento.

A Figura 10 sugere que a micorrização das mudas nos tratamentos que utilizaram substrato comercial foi distintamente superior aos tratamentos com vermicomposto (mistura $50 \%$ ou 100\%), exceto para a variedade Pêra inoculada, variedade Escape inoculada e variedade Natal não inoculada. Essa tendência é verificada para as demais variedades sob efeito de inoculação ou não inoculação. Quando comparados, contudo, a micorrização observada nos tratamentos vermicomposto (100\%) e mistura (50\%), apresentaram-se mais próximos.

A análise de variância, cujos resultados são sumarizados na Tabela 5, apresentada na seção 4.3, indica significância estatística ao nível de 0,1\% para os efeitos associados aos fatores variedade, substrato, interação variedade-substrato e interação variedade-inoculação-substrato. 


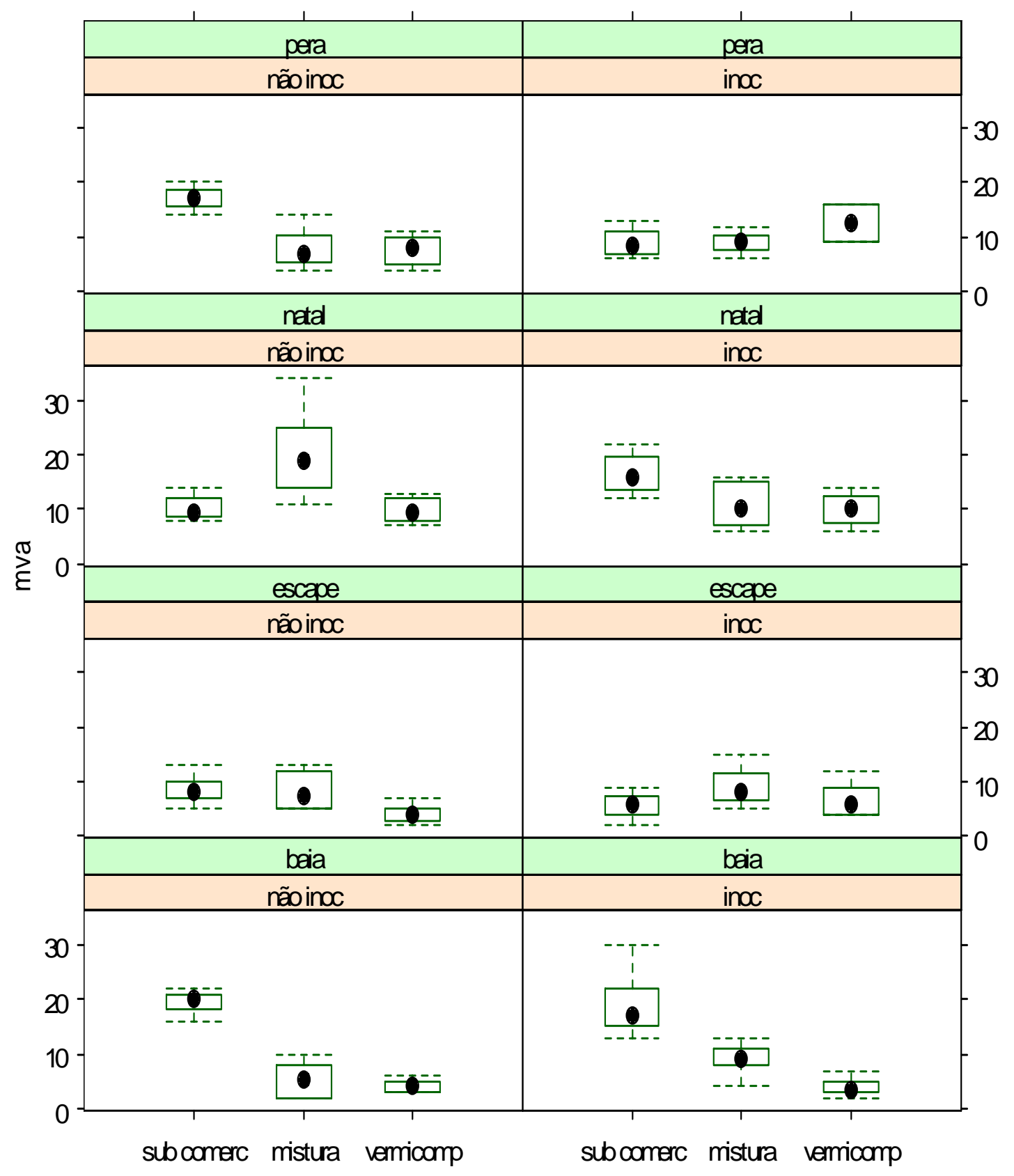

Figura 10 - Diagrama de Tukey da micorrização em porcentagem, por substrato, variedade e tipo de inoculação 


\subsubsection{Impacto no DRIS - Índice de Balanço Nutricional (IBN)}

A Figura 11 apresenta diagramas de Tukey contendo o Índice de Balanço Nutricional obtido no experimento.

A Figura 11 sugere que o Índice de Balanço Nutricional das mudas nos tratamentos que utilizaram substrato comercial foi distintamente superior aos tratamentos com vermicomposto (mistura 50\% ou 100\%). Quando comparados, contudo, a micorrização observada nos tratamentos vermicomposto (100\%) e mistura (50\%), apresentaram-se mais próximos, com exceção a variedade Natal não inoculada, onde o Índice de Balanço Nutricional tende a ser maior na mistura (50\%) que no vermicomposto puro, enquanto na variedade Pêra não inoculada existe uma leve tendência de superioridade do vermicomposto em relação à mistura (50\%).

A análise de variância, cujos resultados são sumarizados na Tabela 5, apresentada na seção 4.3, indica significância estatística para os efeitos associados ao fator substrato (nível de 0,1\%), variedade (nível de 5\%), interação variedade-inoculação (nível 1\%) e variedade-substrato (nível de 1\%).

No anexo A.2, encontra-se a representação gráfica do comportamento dos teores foliares de macro e micronutrientes (combinados 2 a 2) dentro de variedade, substrato e sob efeito de inoculação ou não. 


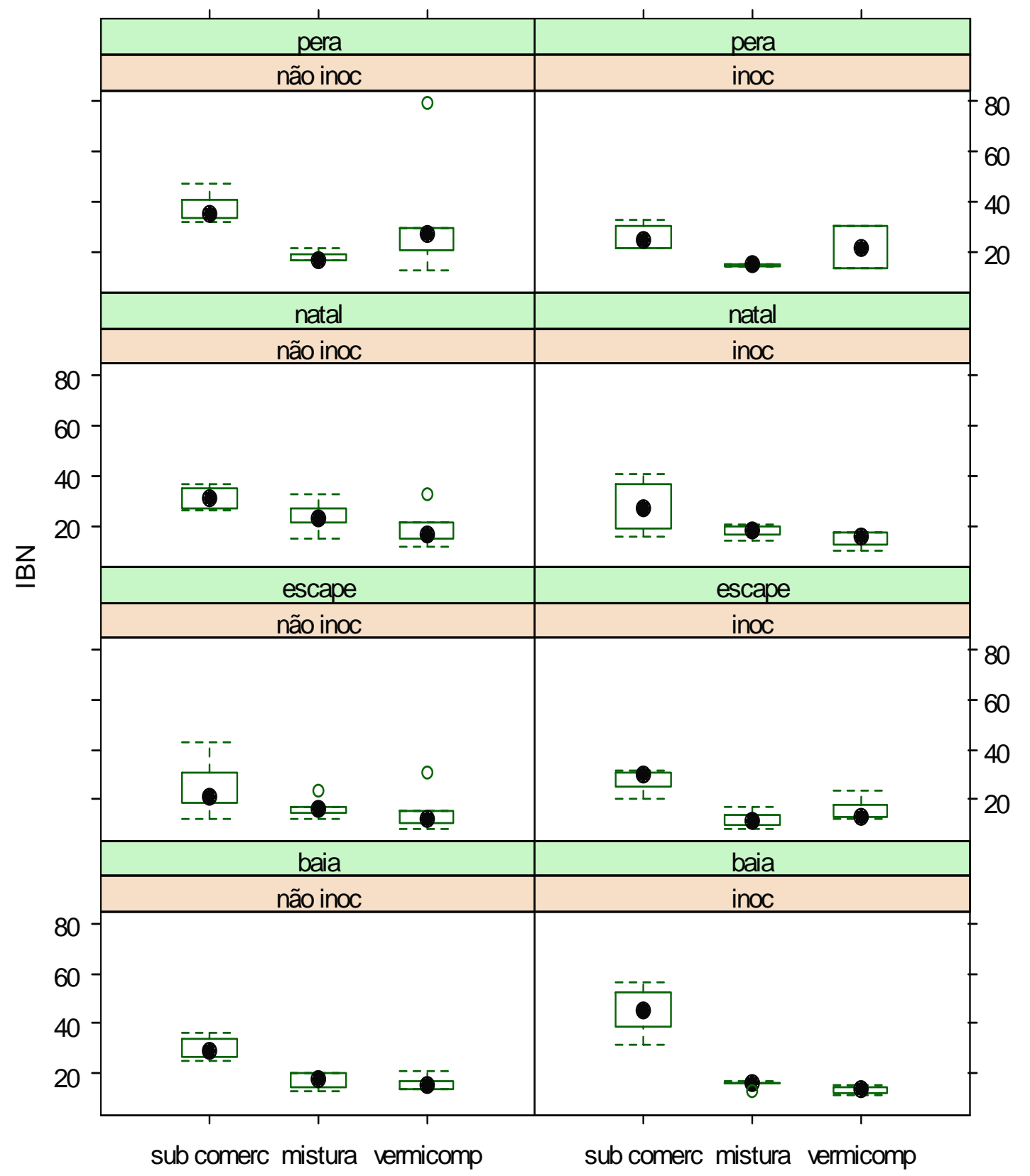

Figura 11 - Diagrama de Tukey do Índice de Balanço Nutricional, por substrato, variedade e tipo de inoculação 


\subsection{Comportamento de indicadores biométricos ( 2 a 2 )}

A Figura 12 apresenta diagramas de dispersão contendo o peso da matéria seca da parte aérea e do sistema radicular, assim como uma regressão entre os valores observados, em cada variedade.

Os símbolos que representam os pontos nos diagramas indicam substrato (s-substrato comercial; m-mistura; v-vermicomposto) e tipo de inoculação (cinza-não inoculado; preto-inoculado). Os diagramas apresentam a estimativas dos parâmetros da regressão linear simples, o R2, e o nível de significância (se houver) associado ao coeficiente angular $(* * *=0,1 \% ; * *=1 \%$ e $*=5 \%)$ estimado. $O$ coeficiente angular, nas 4 variedades, varia de 1,13 a 1,39 indicam que para cada 1 grama de aumento na matéria seca do sistema radicular, observa-se entre 1,13 e 1,39 gramas de aumento na matéria seca da parte aérea (em média). As mudas associadas aos tratamentos vermicomposto (v) e mistura (m), tendem a ter mais matéria seca tanto na parte aérea quanto na radicular. O impacto da inoculação não pode ser observado nos diagramas. 
Baia

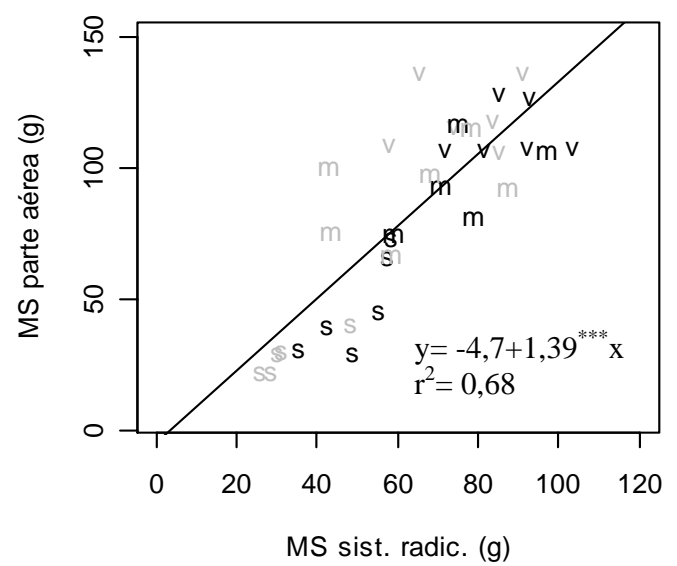

Natal

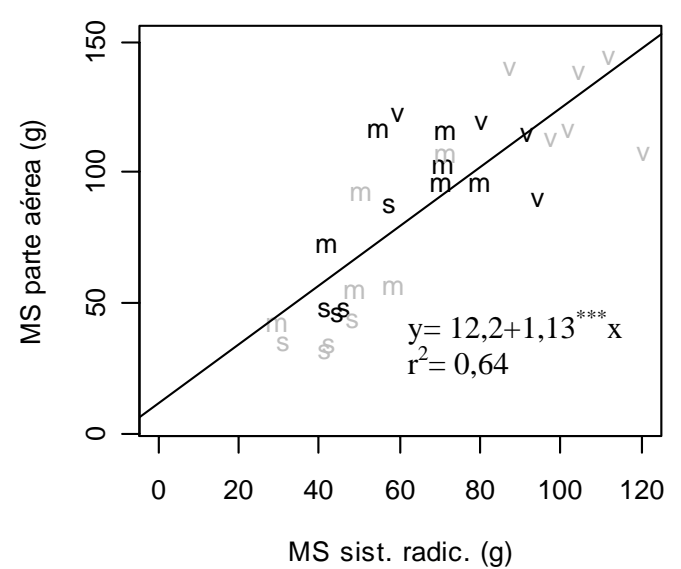

Escape

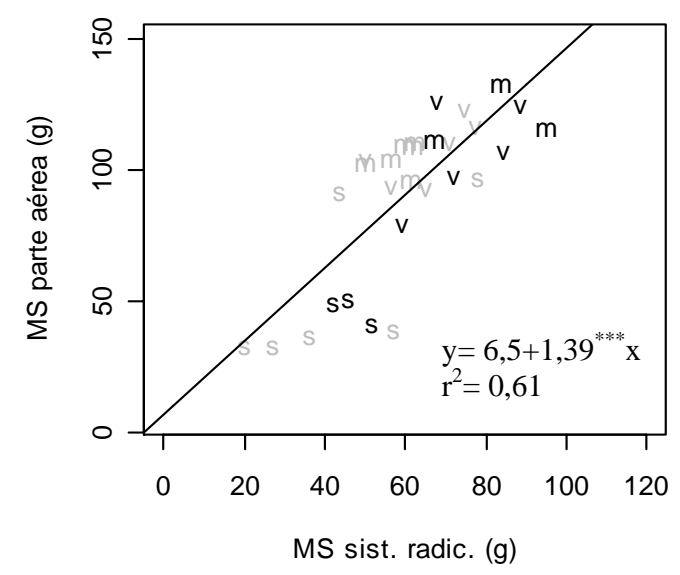

Pêra

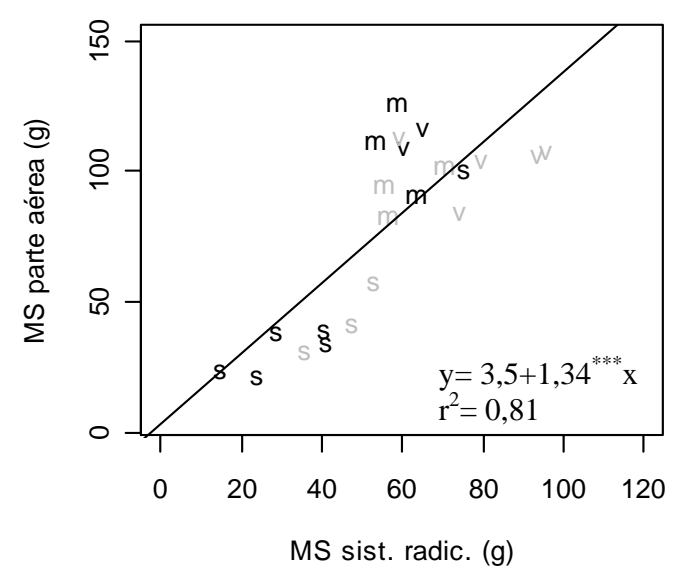

Figura 12 - Diagrama de dispersão do peso seco e regressão da M.S. da parte aérea(g) e do sistema radicular(g), por variedade, substrato (s-substrato comercial; mmistura; v- vermicomposto) e tipo de inoculação (cinza-não inoculado; preto-inoculado) 
A Figura 13 apresenta diagramas de dispersão contendo o peso da matéria seca da parte aérea e o Índice de Balanço Nutricional (IBN), assim como uma regressão entre os valores observados, em cada variedade.

Os símbolos que representam os pontos nos diagramas indicam substrato (s-substrato comercial; m-mistura; v-vermicomposto) e tipo de inoculação (cinza-não inoculado; preto-inoculado). Os diagramas apresentam as estimativas dos parâmetros da regressão linear simples, o R2, e o nível de significância (se houver) associado ao coeficiente angular $\left(* * *=0,1 \% ; * *=1 \% \mathrm{e}^{*}=5 \%\right)$ estimado. $\mathrm{O}$ coeficiente angular, nas 4 variedades, varia de -0,44 e -2,87, indicam que para cada unidade de aumento no IBN, observa-se entre -0,44 e -2,87 gramas de diminuição na matéria seca da parte aérea (em média). As mudas associadas aos tratamentos vermicomposto (v) e mistura (m), tendem a ter mais matéria seca na parte aérea e menor IBN, enquanto as mudas associadas ao tratamento com substrato comercial apresentam menor matéria seca na parte aérea e IBN maior. Na variedade Pêra este fato é menos evidenciado. O impacto da inoculação não pode ser observado nos diagramas. 
Baia

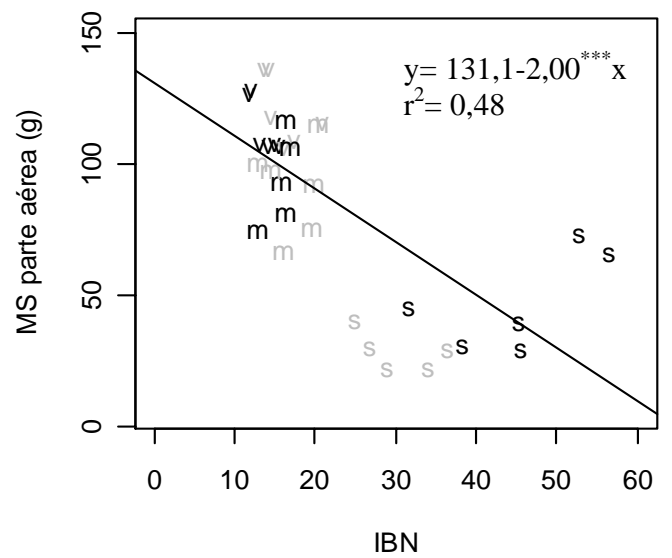

Natal

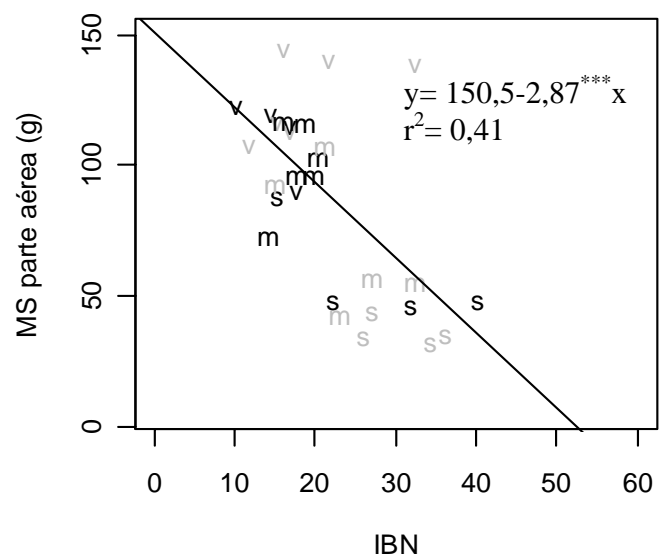

Escape

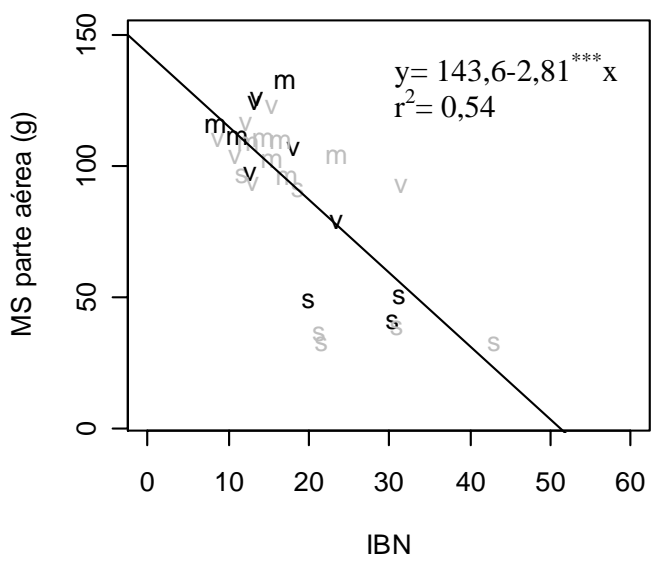

Pêra

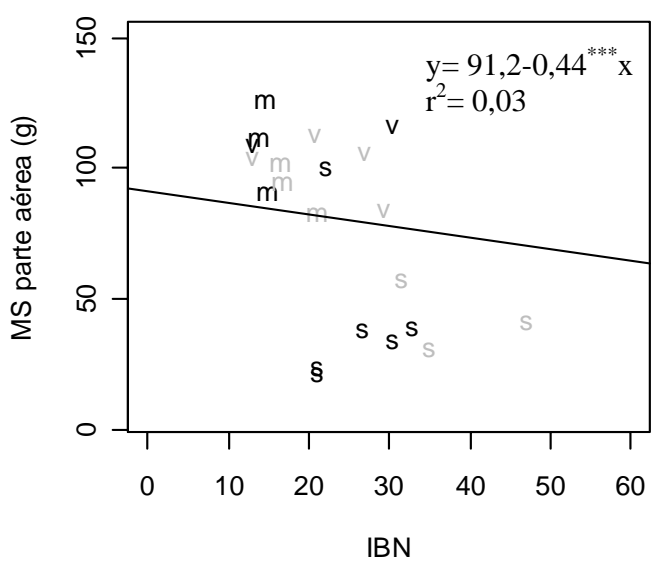

Figura 13 - Diagrama de dispersão do peso seco e regressão da M.S. da parte aérea(g) e do Índice de Balanço Nutricional, por variedade, substrato (s-substrato comercial; m-mistura; v- vermicomposto) e tipo de inoculação (cinza-não inoculado; preto-inoculado) 
A Figura 14 apresenta diagramas de dispersão contendo o peso da matéria seca do sistema radicular e o Índice de Balanço Nutricional (IBN), assim como uma regressão entre os valores observados, em cada variedade.

Os símbolos que representam os pontos nos diagramas indicam substrato (s-substrato comercial; m-mistura; v-vermicomposto) e tipo de inoculação (cinza-não inoculado; preto-inoculado). Os diagramas apresentam as estimativas dos parâmetros da regressão linear simples, o R2, e o nível de significância (se houver) associado ao coeficiente angular $\left(* * *=0,1 \% ; * *=1 \% \mathrm{e}^{*}=5 \%\right)$ estimado. $\mathrm{O}$ coeficiente angular, nas 4 variedades, varia de $-0,30$ e $-1,50$, indicam que para cada unidade de aumento no IBN, observa-se entre -0,30 e -1,50 grama de diminuição na matéria seca do sistema radicular (em média). As mudas associadas aos tratamentos vermicomposto (v) e mistura (m), tendem a ter matéria seca no sistema radicular maior e menor IBN, enquanto as mudas associadas ao tratamento com substrato comercial apresentam matéria seca da parte aérea menor e IBN maior. Na variedade Pêra este fato é menos evidenciado. O impacto da inoculação não pode ser observado nos diagramas. 

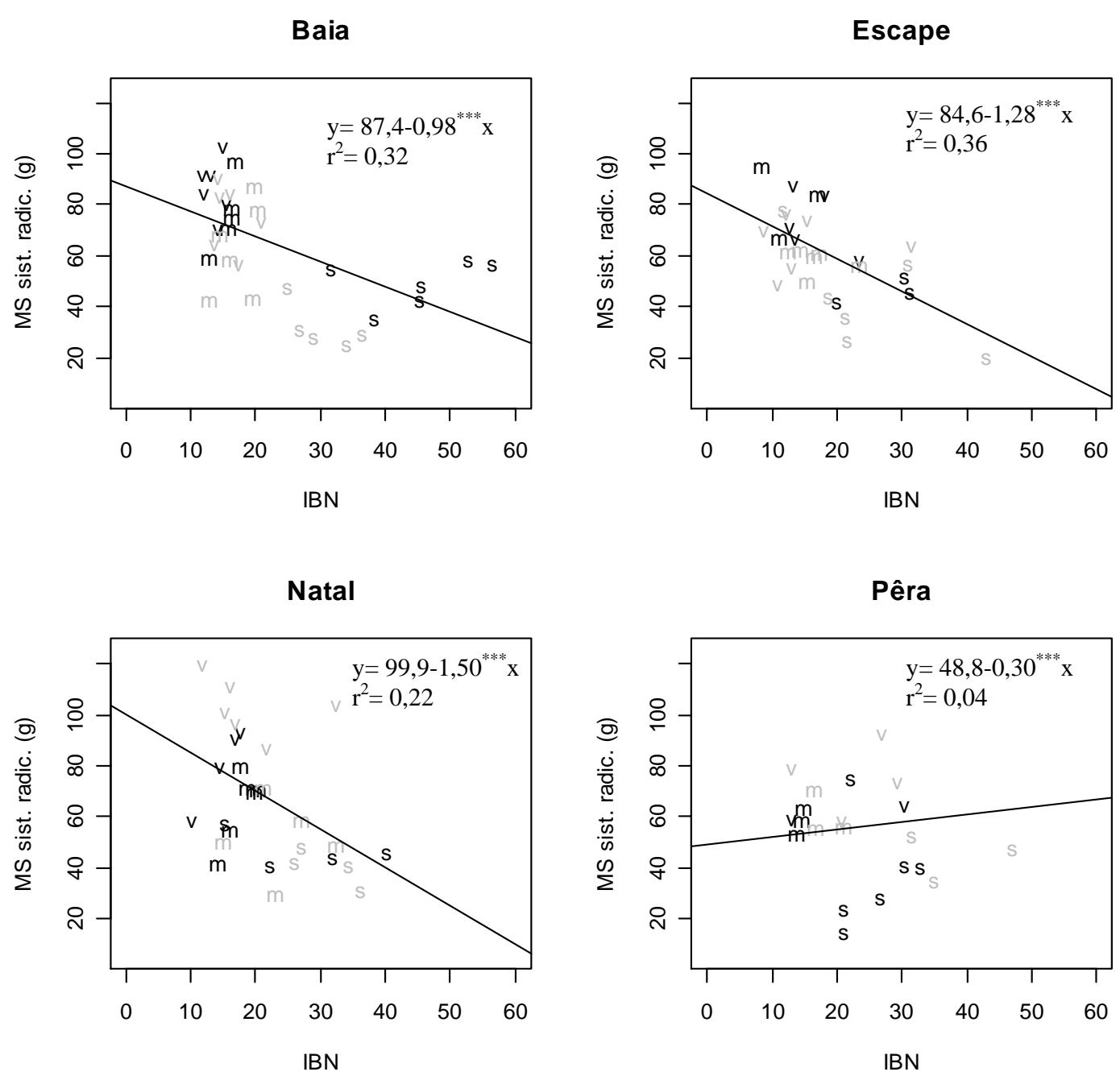

Figura 14 - Diagrama de dispersão do peso seco e regressão da M.S. do sistema radicular (g) e Índice de Balanço Nutricional, por variedade, substrato (s-substrato comercial; m-mistura; v- vermicomposto) e tipo de inoculação (cinza-não inoculado; preto-inoculado)

A Figura 15 apresenta diagramas de dispersão contendo o peso da matéria seca do sistema radicular e taxa de micorrização (mva (\%)), assim como uma regressão entre os valores observados, em cada variedade. 
Os símbolos que representam os pontos nos diagramas indicam substrato (s-substrato comercial; m-mistura; v-vermicomposto) e tipo de inoculação (cinza-não inoculado; preto-inoculado). Os diagramas apresentam as estimativas dos parâmetros da regressão linear simples, o R2, e o nível de significância (se houver) associado ao coeficiente angular $(* * *=0,1 \% ; * *=1 \%$ e $*=5 \%)$ estimado. $\mathrm{O}$ coeficiente angular, nas 4 variedades, varia de -0,14 a -1,98, indicam que para cada unidade de aumento na taxa de micorrização (mva (\%)), observa-se entre -0,14 a -1,98 grama de diminuição na matéria seca do sistema radicular (em média). Nas variedades Baia e Natal, as mudas associadas aos tratamentos vermicomposto $(\mathrm{v})$ e mistura $(\mathrm{m})$, tendem a ter mais matéria seca no sistema radicular e menor taxa de micorrização, enquanto no tratamento associado ao substrato comercial tende a ter menos matéria seca no sistema radicular e maior taxa de micorrização. Este fato não é observado nas variedades Escape e Pêra. 
Baia

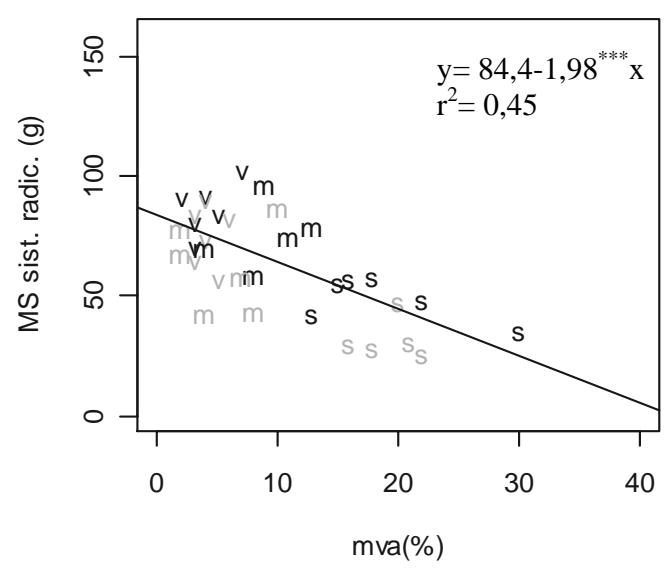

Natal

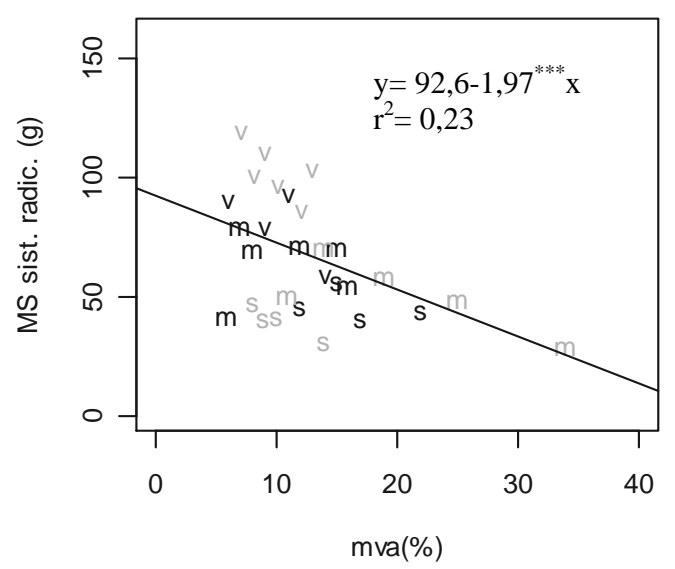

Escape

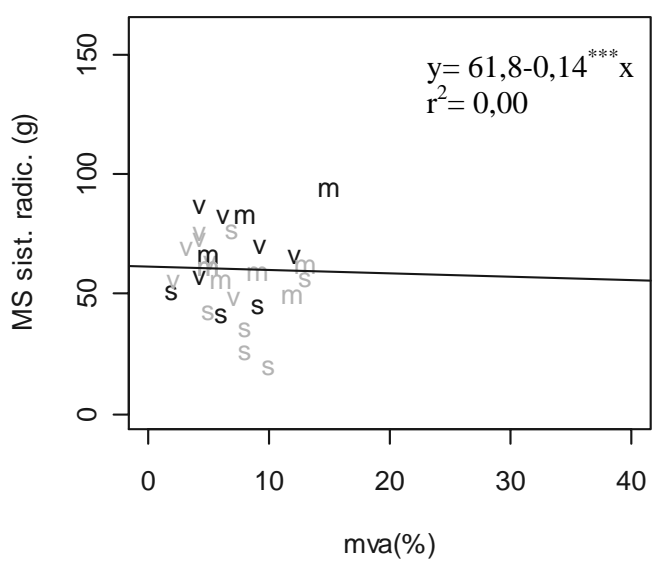

Pêra

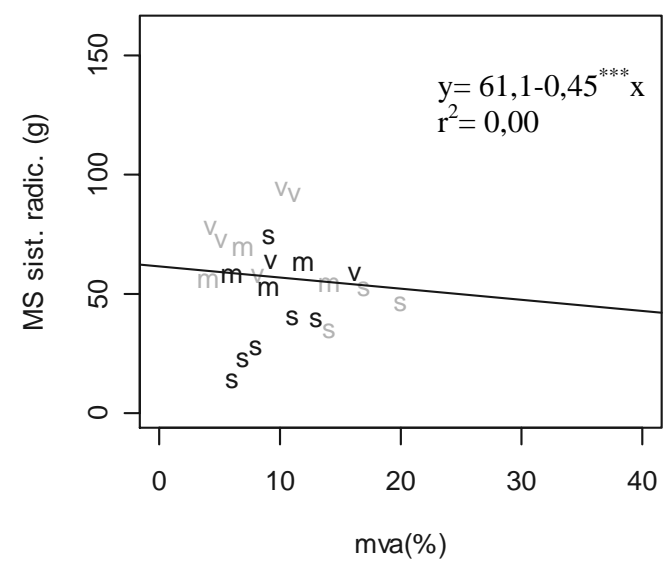

Figura 15 - Diagrama de dispersão do peso seco e regressão da M.S. do sistema radicular(g) e taxa de micorrização(\%), por variedade, substrato (ssubstrato comercial; m-mistura; v- vermicomposto) e tipo de inoculação (cinza-não inoculado; preto-inoculado). 
A Figura 16 apresenta diagramas de dispersão contendo o diâmetro do caule e peso da matéria seca do sistema radicular, assim como uma regressão entre os valores observados, em cada variedade.

Os símbolos que representam os pontos nos diagramas indicam substrato (s-substrato comercial; m-mistura; v-vermicomposto) e tipo de inoculação (cinza-não inoculado; preto-inoculado). Os diagramas apresentam a estimativas dos parâmetros da regressão linear simples, o R2, e o nível de significância (se houver) associado ao coeficiente angular $(* * *=0,1 \% ; * *=1 \%$ e $*=5 \%)$ estimado. $O$ coeficiente angular, nas 4 variedades, varia de 0,06 a 0,09 indicam que para cada 1 grama de aumento na matéria seca do sistema radicular, observa-se entre 0,06 a 0,09 mm de aumento no diâmetro do caule (em média). As mudas associadas aos tratamentos vermicomposto (v) e mistura (m), tendem a ter mais matéria seca no sistema radicular e maior diâmetro de caule. $\mathrm{O}$ impacto da inoculação não pode ser observado nos diagramas. 
Baia

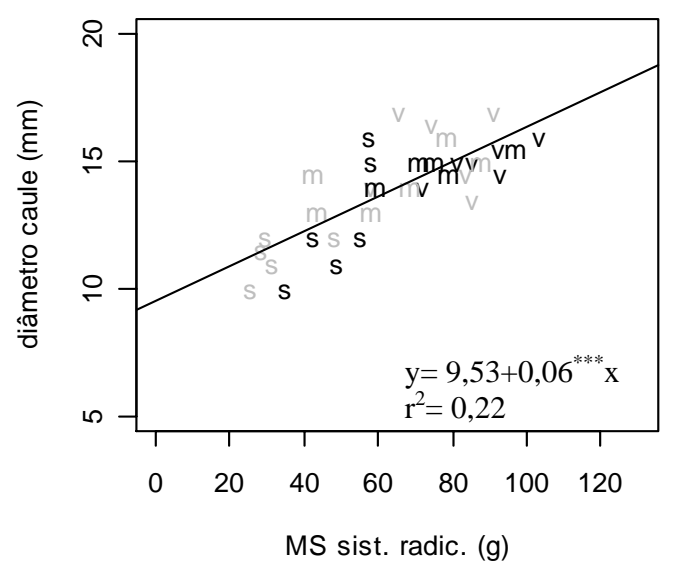

Natal

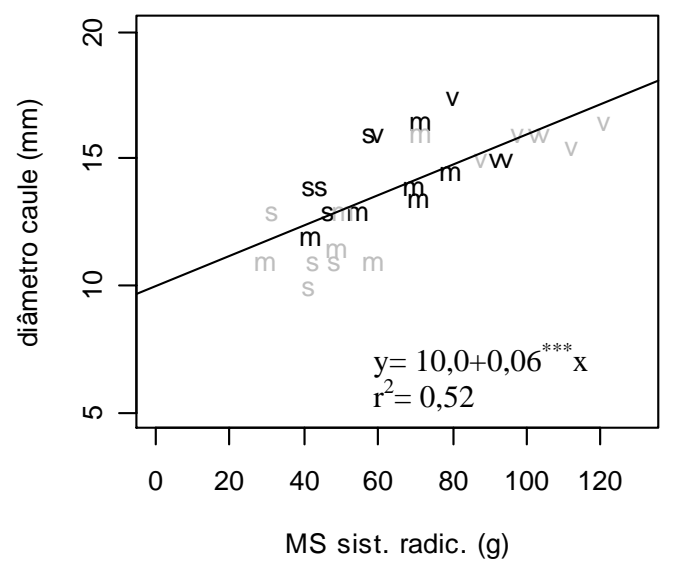

Escape

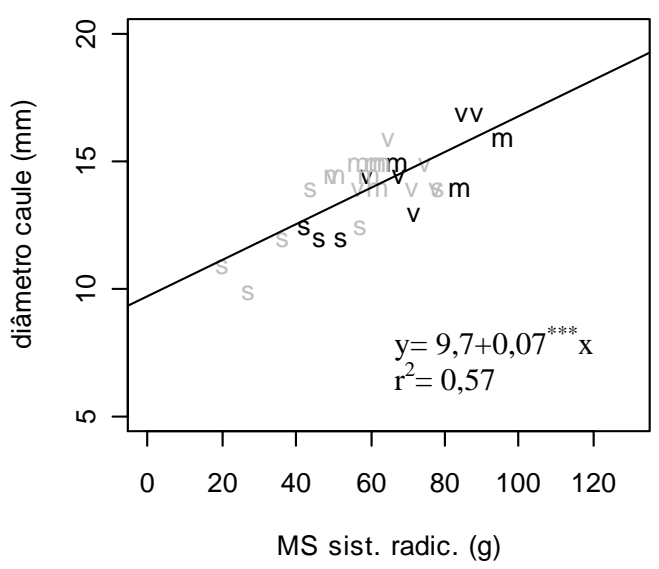

Pêra

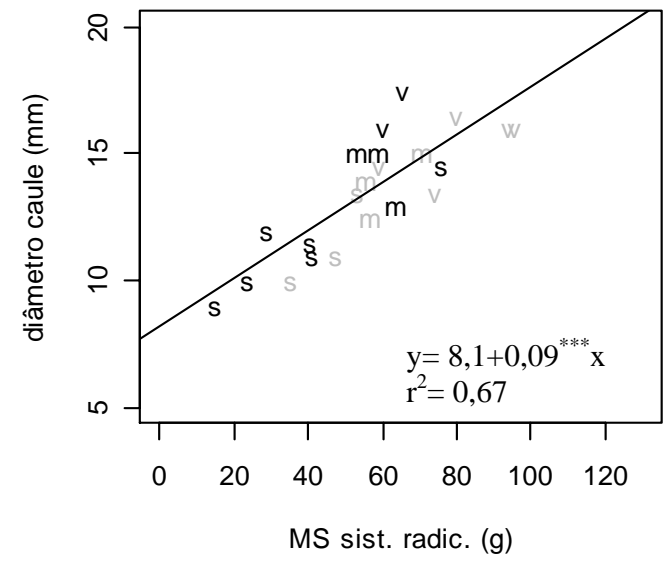

Figura 16 - Diagrama de dispersão do diâmetro do caule (mm) e regressão da M.S. do sistema radicular(g), por variedade, substrato (s-substrato comercial; mmistura; v- vermicomposto) e tipo de inoculação (cinza-não inoculado; preto-inoculado) 
A Figura 17 apresenta diagramas de dispersão contendo o peso da matéria seca da parte aérea e do sistema radicular, assim como uma regressão entre os valores observados, em cada variedade.

Os símbolos que representam os pontos nos diagramas indicam substrato (ssubstrato comercial; m-mistura; v-vermicomposto) e tipo de inoculação (cinza-não inoculado; preto-inoculado). Os diagramas apresentam as estimativas dos parâmetros da regressão linear simples, o R2, e o nível de significância (se houver) associado ao coeficiente angular (*** $=0,1 \%$; $\left.* *=1 \% \mathrm{e}^{*}=5 \%\right)$ estimado. O coeficiente angular, nas 4 variedades, varia de 13,5 a 16,4 indicam que para cada $1 \mathrm{~mm}$ de aumento no diâmetro do caule, observa-se entre 13,5 a 16,4 gramas de aumento na matéria seca da parte aérea (em média). As mudas associadas aos tratamentos vermicomposto (v) e mistura (m), tendem a ter mais matéria seca na parte aérea e maior diâmetro de caule. O impacto da inoculação não pode ser observado nos diagramas. 
Baia

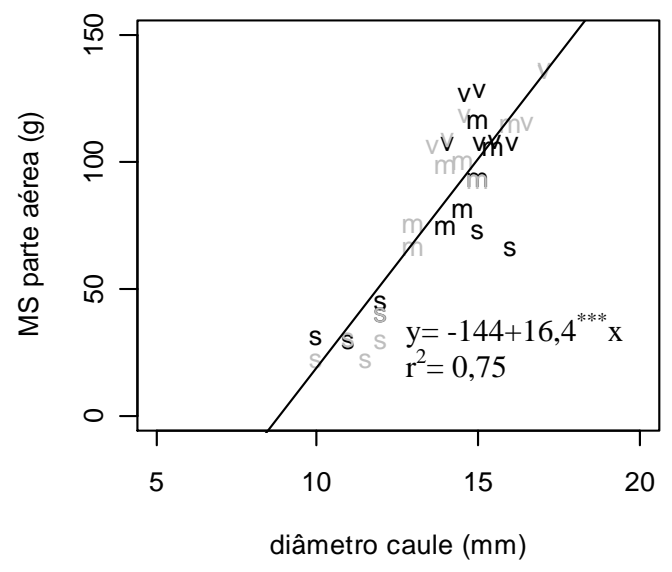

Natal

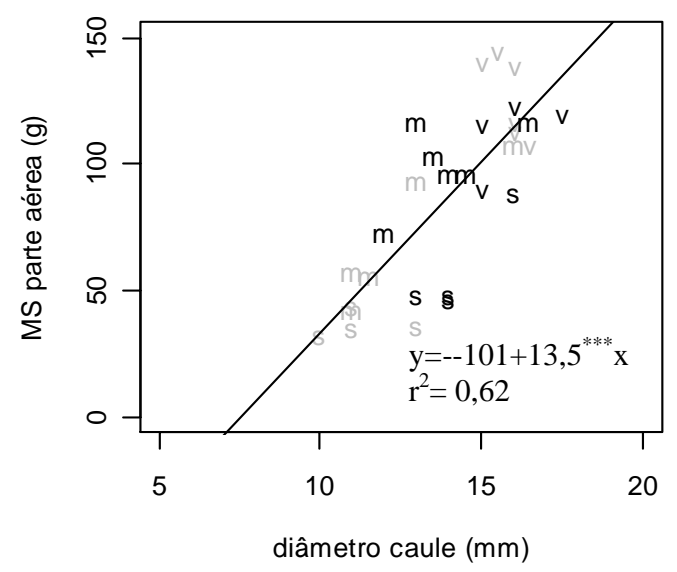

Escape

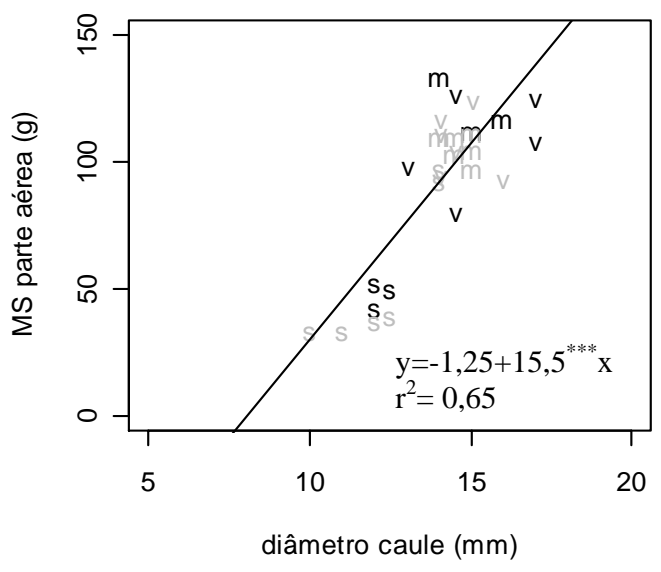

Pêra

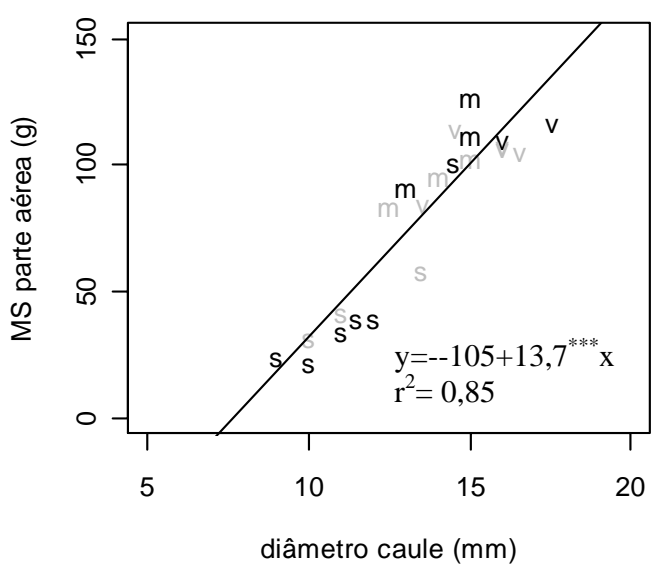

Figura 17 - Diagrama de dispersão do peso seco e regressão da M.S. da parte aérea (g) e diâmetro do caule(mm), por variedade, substrato (s-substrato comercial; mmistura; v- vermicomposto) e tipo de inoculação (cinza-não inoculado; preto-inoculado). 
A Figura 18 apresenta diagramas de dispersão contendo a taxa de micorrização (mva (\%)) e Índice de Balanço Nutricional (IBN), assim como uma regressão entre os valores observados, em cada variedade.

Os símbolos que representam os pontos nos diagramas indicam substrato (ssubstrato comercial; m-mistura; v-vermicomposto) e tipo de inoculação (cinza-não inoculado; preto-inoculado). Os diagramas apresentam a estimativas dos parâmetros da regressão linear simples, o R2, e o nível de significância (se houver) associado ao coeficiente angular $(* * *=0,1 \% ; * *=1 \%$ e $*=5 \%)$ estimado. $\mathrm{O}$ coeficiente angular, nas 4 variedades, varia de 0,03 a 0,44, indicam que para cada unidade de aumento no IBN, observa-se entre 0,03 a 0,44 grama de aumento na taxa de micorrizacão (em média). As mudas associadas aos tratamentos vermicomposto (v) e mistura (m), tendem a ter menor taxa de micorrização e menor IBN, este fato é mais evidente nas variedades Baia e Natal. O impacto da inoculação não pode ser observado nos diagramas. 
Baia

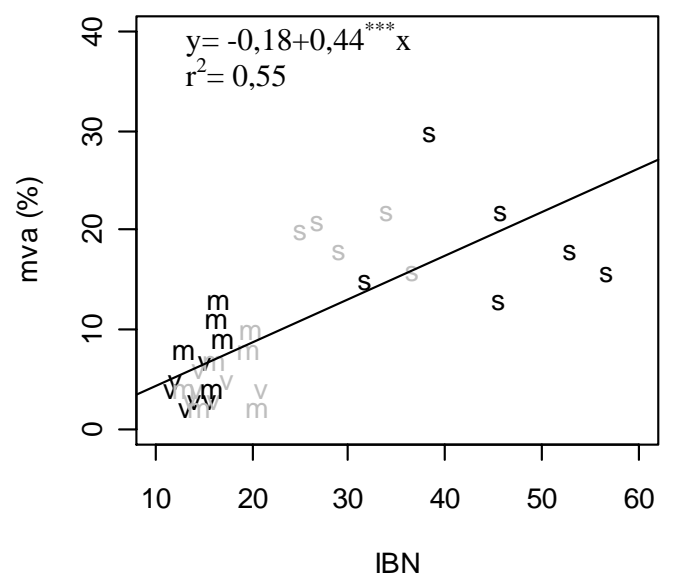

Natal

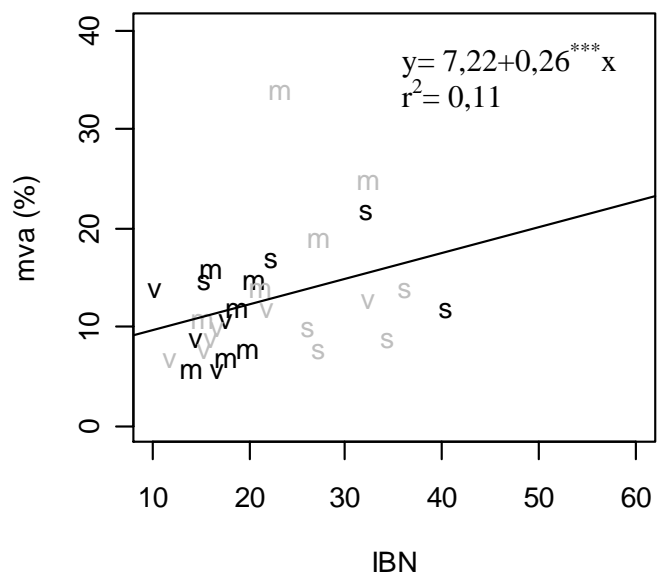

Escape

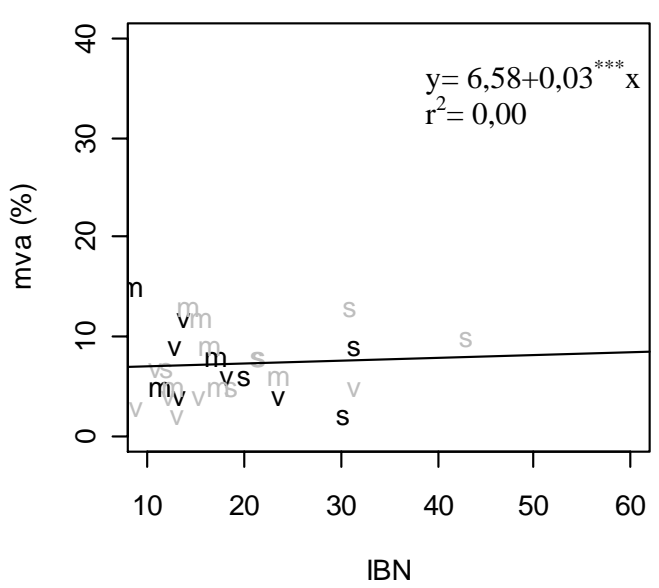

Pêra

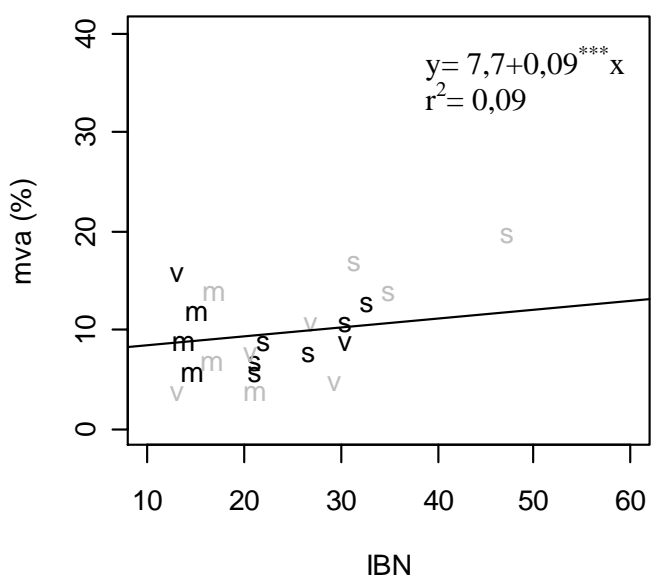

Figura 18 - Diagrama de dispersão da taxa de micorrização e regressão e Índice de Balanço Nutricional, por variedade, substrato (s-substrato comercial; mmistura; v- vermicomposto) e tipo de inoculação (cinza-não inoculado; preto-inoculado) 
A Figura 19 apresenta diagramas de dispersão contendo o diâmetro do caule e Índice de Balanço Nutricional (IBN), assim como uma regressão entre os valores observados, em cada variedade.

Os símbolos que representam os pontos nos diagramas indicam substrato (s-substrato comercial; m-mistura; v-vermicomposto) e tipo de inoculação (cinza-não inoculado; preto-inoculado). Os diagramas apresentam a estimativas dos parâmetros da regressão linear simples, o R2, e o nível de significância (se houver) associado ao coeficiente angular $(* * *=0,1 \% ; * *=1 \%$ e $*=5 \%)$ estimado. $\mathrm{O}$ coeficiente angular, nas 4 variedades, varia de -0,001 a -0,14 indicam que para cada unidade de aumento do IBN, observa-se entre -0,001 a -0,14 grama de diminuição no diâmetro do tronco (em média). As mudas associadas aos tratamentos vermicomposto (v) e mistura (m), tendem a ter diâmetro do tronco maior e menor IBN. O impacto da inoculação não pode ser observado nos diagramas. 
Baia

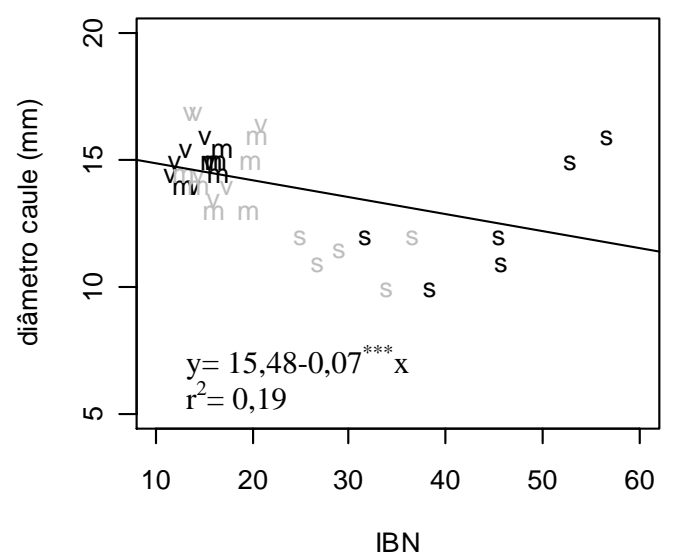

Natal

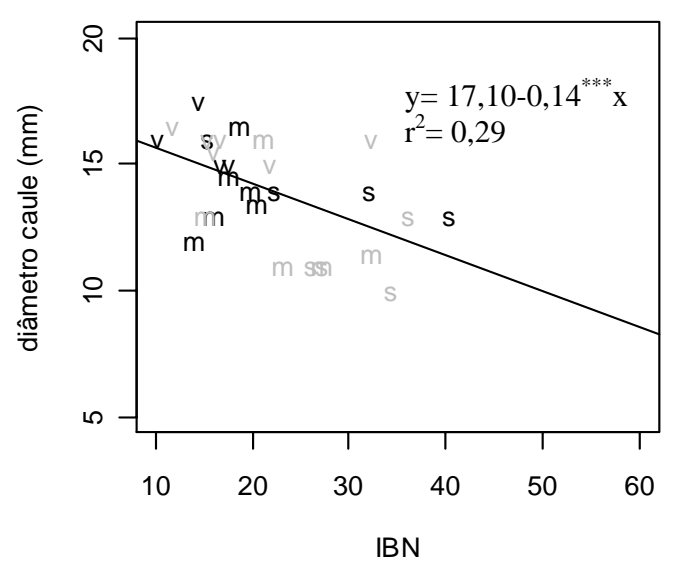

Escape

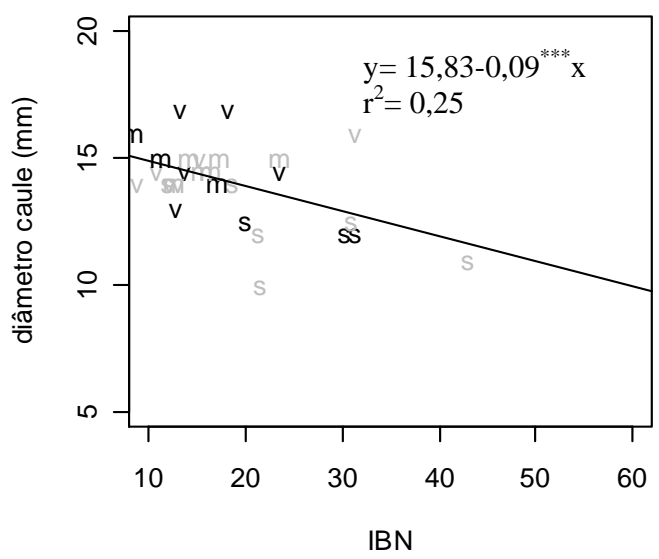

Pêra

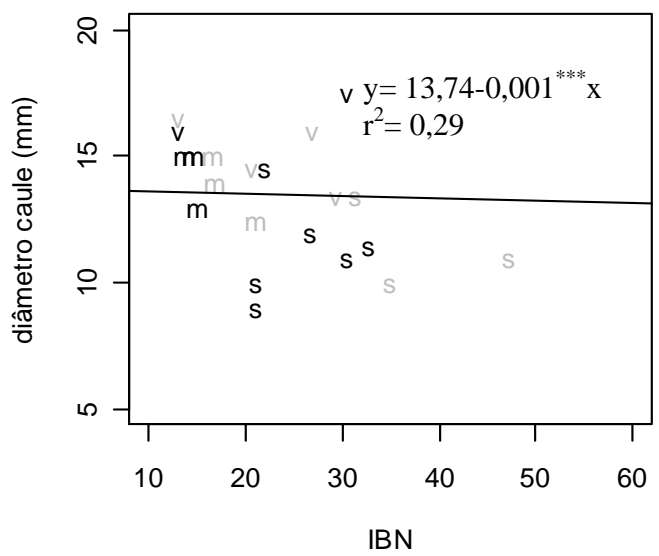

Figura 19 - Diagrama de dispersão do diâmetro do caule(mm) e regressão do diâmetro do caule(mm) e Índice de Balanço Nutricional, por variedade, substrato (ssubstrato comercial; m-mistura; v- vermicomposto) e tipo de inoculação (cinza-não inoculado; preto-inoculado). 
A Figura 20 apresenta diagramas de dispersão contendo a altura da planta e o Índice de Balanço Nutricional (IBN), assim como uma regressão entre os valores observados, em cada variedade.

Os símbolos que representam os pontos nos diagramas indicam substrato (ssubstrato comercial; m-mistura; v-vermicomposto) e tipo de inoculação (cinza-não inoculado; preto-inoculado). Os diagramas apresentam a estimativas dos parâmetros da regressão linear simples, o R2, e o nível de significância (se houver) associado ao coeficiente angular $(* * *=0,1 \% ; * *=1 \% \mathrm{e} *=5 \%)$ estimado. $\mathrm{O}$ coeficiente angular, nas 4 variedades, variando de $-0,18$ a $-1,05$ indica que para cada unidade de aumento no IBN, observa-se entre -0,18 a -1,05 grama de decréscimo na altura da planta (em média). As mudas associadas aos tratamentos vermicomposto (v) e mistura (m), tendem a ter mais matéria seca tanto na parte aérea quanto na radicular. O impacto da inoculação não pode ser observado nos diagramas. 

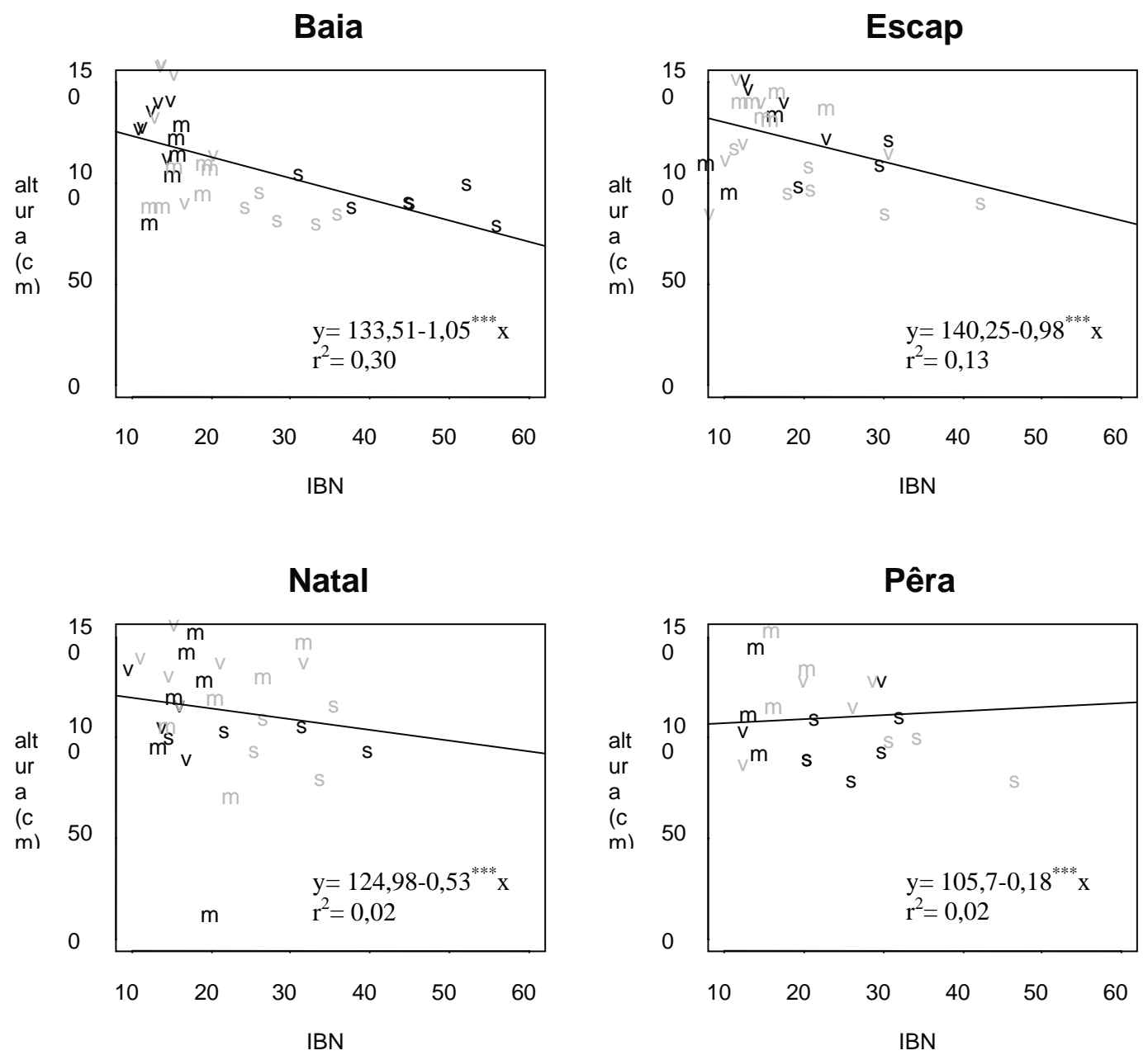

Figura 20 - Diagrama de dispersão da altura da planta(cm) e regressão da altura da planta (cm) e Índice de Balanço Nutricional, por variedade, substrato (ssubstrato comercial; m-mistura; v- vermicomposto) e tipo de inoculação (cinza-não inoculado; preto-inoculado) 
A Figura 21 apresenta diagramas de dispersão contendo o teor foliar de Fósforo e da taxa de micorrização (mva(\%)), assim como uma regressão entre os valores observados, em cada variedade.

Os símbolos que representam os pontos nos diagramas indicam substrato (ssubstrato comercial; m-mistura; v-vermicomposto) e tipo de inoculação (cinza-não inoculado; preto-inoculado). Os diagramas apresentam a estimativas dos parâmetros da regressão linear simples, o R2, e o nível de significância (se houver) associado ao coeficiente angular $(* * *=0,1 \% ; * *=1 \%$ e $*=5 \%)$ estimado. $\mathrm{O}$ coeficiente angular, nas 4 variedades, variam de 0,08 a 0,22, indicam que para cada uma unidade de aumento na taxa de micorrização (mva (\%)), observa-se entre 0,08 a 0,22 gramas de aumento no teor foliar de Fósforo (em média). 

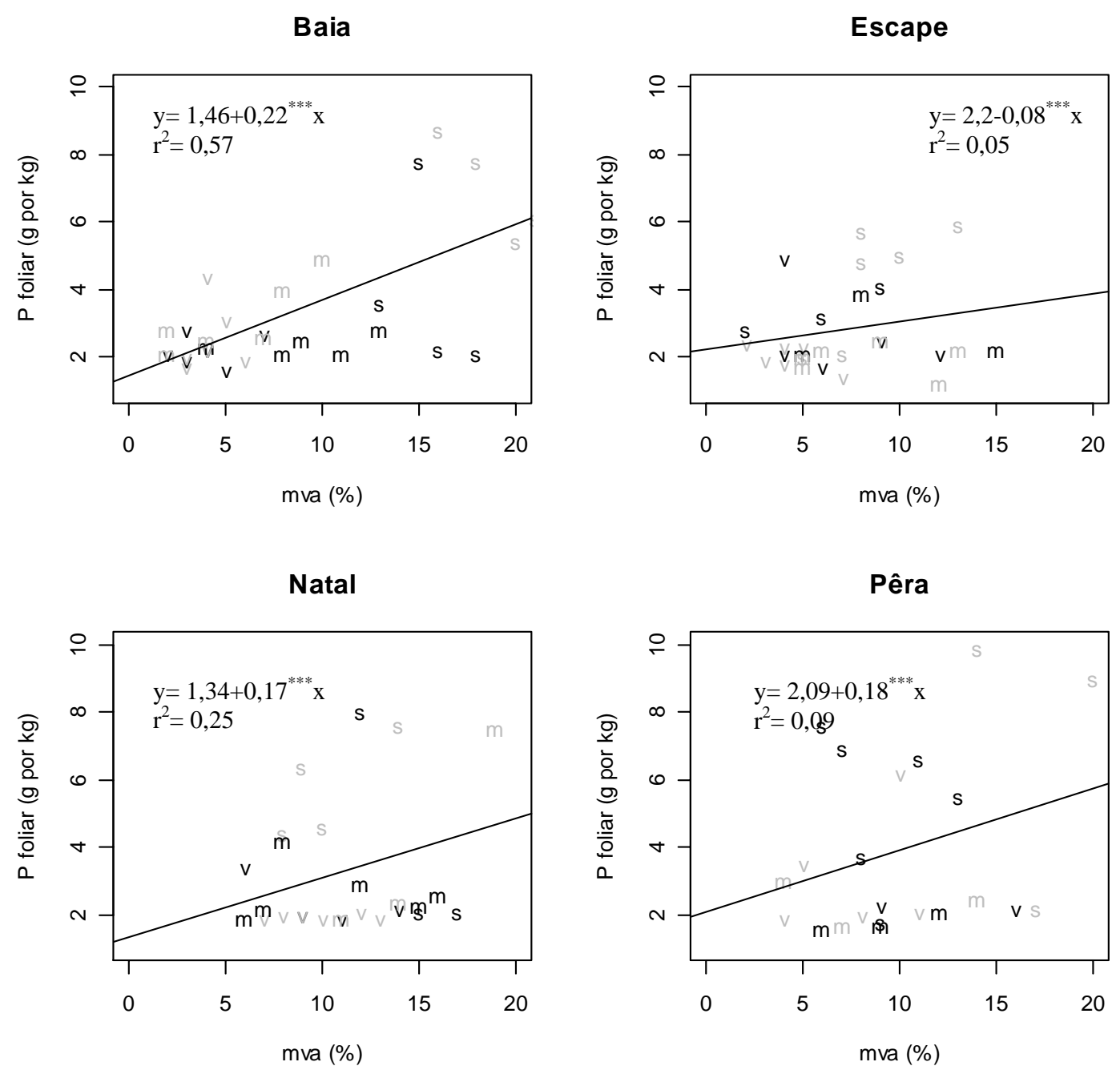

Figura 21 - Diagrama do teor foliar de fósforo e regressão do teor foliar de fósforo (g kg${ }^{1}$ ) e taxa de micorrização(\%), por variedade, substrato (s-substrato comercial; m-mistura; v- vermicomposto) e tipo de inoculação (cinza-não inoculado; preto-inoculado) 


\section{CONCLUSÕES}

Os resultados obtidos no presente trabalho permitem as seguintes conclusões:

a) Para os pesos da matéria seca da parte aérea e do sistema radicular, os maiores valores foram obtidos nos tratamentos com substrato a base de vermicomposto (100\%), seguido de vermicomposto (50\%) e por último o substrato comercial. Isto foi observado em todas as variedades com ou sem inoculação. A maior média foi para a variedade Natal não inoculada no substrato de vermicomposto $100 \%$, sendo 127,19 g para a parte aérea e 103,62 para o sistema radicular. A menor média para variedade Baia não inoculada no substrato comercial, sendo 29,56 g para a parte aérea e 32,7 g para o sistema radicular;

b) Para o diâmetro do caule a $5 \mathrm{~cm}$ de altura do caule, observa-se a mesma tendência do item anterior, sendo que a maior média foi obtida na variedade Pêra inoculada no substrato de vermicomposto $100 \%$ (16,8 mm) e a menor média na variedade Natal não inoculada no substrato comercial (11,3 mm);

c) Quanto à altura das plantas, os tratamentos com vermicomposto (100\% e $50 \%$ mostraram-se superiores ao tratamento com substrato comercial, não havendo grandes diferenças entre os tratamentos com vermicomposto $100 \%$ e vermicomposto 50\%. A maior média foi apresentada pelo tratamento com a variedade Escape inoculada no substrato com vermicomposto 100\% (146 cm) e a menor média para o tratamento com a variedade Baia não inoculada no substrato comercial $(86 \mathrm{~cm})$; 
d) Tanto para a taxa de micorrização quanto para o índice DRIS, observou-se a tendência do substrato comercial apresentar valores maiores em relação aos outros substratos, indicando uma situação de maior estresse nutricional;

e) Observa-se a viabilidade do uso de substrato alternativo na produção de mudas cítricas com melhor desenvolvimento e equilíbrio nutricional;

f) Não foi observada influência significativa da inoculação com Xylella fastidiosa nos parâmetros analisados, exceto para os teores foliares de nitrogênio e fósforo, onde nas plantas inoculadas o teor foliar de nitrogênio $(1,46 \%)$ foi maior em relação às plantas não inoculadas $(1,30 \%)$ e para fósforo ocorreu o oposto (0,32\% e 0,40\%, respectivamente). 
ANEXOS 
A1 - Valores médios e coeficiente de variação dos resultados obtidos nos diferentes tratamentos

Na Tabela 6 observam-se os valores médios de diâmetro do caule, altura da planta, peso da parte aérea, peso do sistema radicular e taxa de micorrização e seus respectivos coeficientes de variação, nos diferentes tratamentos.

A Tabela 7 ilustra os teores foliares médios de macronutrientes e seus coeficientes de variação, nos diferentes tratamentos.

A Tabela 8 ilustra os teores foliares médios de micronutrientes e seus coeficientes de variação, nos diferentes tratamentos. 
Tabela 6. Valores médios de diâmetro do caule, altura da planta, peso da parte aérea, peso do sistema radicular e taxa de micorrização, nos diferentes tratamentos

\begin{tabular}{|c|c|c|c|c|c|}
\hline TRATAMENTO & $\begin{array}{c}\text { DIÂMETRO } \\
(\mathbf{m m})\end{array}$ & $\begin{array}{c}\text { ALTURA } \\
(\mathbf{c m})\end{array}$ & $\begin{array}{c}\text { PMSPA } \\
\text { (g) }\end{array}$ & $\begin{array}{c}\text { PMSSR } \\
\text { (g) }\end{array}$ & $\begin{array}{c}\text { MVA } \\
(\%)\end{array}$ \\
\hline $\mathrm{T} 1$ & 15,00 & 130,67 & 115,08 & 87,36 & 4,00 \\
\hline $\mathrm{T} 2$ & 15,42 & 134,67 & 121,27 & 75,85 & 4,17 \\
\hline $\mathrm{T} 3$ & 12,67 & 92,17 & 48,12 & 49,68 & 19,00 \\
\hline $\mathrm{T} 4$ & 11,30 & 86,20 & 29,56 & 32,72 & 19,40 \\
\hline T5 & 14,80 & 109,80 & 94,99 & 76,29 & 9,00 \\
\hline T6 & 14,25 & 99,17 & 91,82 & 63,20 & 5,50 \\
\hline $\mathrm{T} 7$ & 15,20 & 145,80 & 107,74 & 73,94 & 7,00 \\
\hline $\mathrm{T} 8$ & 14,58 & 120,50 & 107,59 & 65,32 & 4,17 \\
\hline T9 & 12,17 & 109,33 & 47,95 & 46,87 & 5,67 \\
\hline $\mathrm{T} 10$ & 12,25 & 98,67 & 55,52 & 43,84 & 8,50 \\
\hline $\mathrm{T} 11$ & 15,00 & 113,00 & 120,87 & 82,23 & 9,33 \\
\hline $\mathrm{T} 12$ & 14,67 & 137,67 & 105,98 & 58,85 & 8,33 \\
\hline $\mathrm{T} 13$ & 15,88 & 111,25 & 112,57 & 81,08 & 10,00 \\
\hline $\mathrm{T} 14$ & 15,83 & 136,33 & 127,19 & 103,62 & 9,83 \\
\hline $\mathrm{T} 15$ & 14,25 & 101,00 & 58,11 & 47,47 & 16,50 \\
\hline $\mathrm{T} 16$ & 11,25 & 99,75 & 37,16 & 40,85 & 10,25 \\
\hline $\mathrm{T} 17$ & 13,92 & 108,17 & 100,40 & 64,92 & 10,67 \\
\hline T18 & 12,50 & 114,40 & 71,45 & 51,88 & 20,60 \\
\hline T19 & 16,75 & 116,00 & 113,40 & 62,35 & 12,50 \\
\hline $\mathrm{T} 20$ & 15,30 & 120,80 & 103,69 & 80,03 & 7,60 \\
\hline $\mathrm{T} 21$ & 11,33 & 95,17 & 43,69 & 37,56 & 9,00 \\
\hline $\mathrm{T} 22$ & 11,50 & 92,67 & 44,25 & 45,40 & 17,00 \\
\hline $\mathrm{T} 23$ & 14,33 & 116,00 & 110,04 & 58,66 & 9,00 \\
\hline $\mathrm{T} 24$ & 13,83 & 134,00 & 94,04 & 60,86 & 8,33 \\
\hline $\mathrm{CV} \%$ & 11,78 & 14,51 & 36,78 & 28,60 & 47,73 \\
\hline
\end{tabular}

Diâmetro = diâmetro do caule, a $10 \mathrm{~cm}$ do colo da planta; $\quad$ Altura = altura da planta; Pmspa = peso da matéria seca da parte aérea; $\mathrm{Pmssr}=$ peso da matéria seca do sistema radicular; $\mathrm{MVA}=$ taxa de micorrização; $\mathrm{cv} \%=$ coeficiente de variação. 
Tabela 7. Teores foliares médios de macronutrientes, nos diferentes tratamentos

\begin{tabular}{|c|c|c|c|c|c|c|}
\hline \multirow{2}{*}{ TRATAMENTO } & $\mathbf{N}$ & $\mathbf{P}$ & $\mathbf{K}$ & Ca & Mg & S \\
\hline & \multicolumn{6}{|c|}{$\mathrm{mg} \mathrm{kg}^{-1}$} \\
\hline $\mathrm{T} 1$ & 15,83 & 2,22 & 15,43 & 24,97 & 2,15 & 3,15 \\
\hline $\mathrm{T} 2$ & 14,23 & 2,55 & 16,17 & 23,85 & 1,92 & 2,67 \\
\hline $\mathrm{T} 3$ & 17,33 & 5,13 & 28,33 & 24,32 & 22,57 & 5,52 \\
\hline $\mathrm{T} 4$ & 13,68 & 6,94 & 31,12 & 23,28 & 3,12 & 6,48 \\
\hline T5 & 15,00 & 2,36 & 24,16 & 26,52 & 1,88 & 3,72 \\
\hline T6 & 13,90 & 3,15 & 23,63 & 23,60 & 2,10 & 2,77 \\
\hline $\mathrm{T} 7$ & 14,52 & 2,66 & 13,00 & 31,02 & 2,48 & 2,94 \\
\hline $\mathrm{T} 8$ & 14,25 & 2,02 & 13,33 & 32,53 & 2,83 & 3,27 \\
\hline T9 & 8,93 & 3,37 & 24,30 & 28,67 & 4,37 & 5,17 \\
\hline $\mathrm{T} 10$ & 11,48 & 4,25 & 19,98 & 30,90 & 3,08 & 4,93 \\
\hline $\mathrm{T} 11$ & 17,73 & 2,73 & 17,83 & 26,63 & 2,40 & 3,13 \\
\hline $\mathrm{T} 12$ & 11,52 & 1,97 & 20,33 & 29,77 & 1,95 & 3,98 \\
\hline $\mathrm{T} 13$ & 17,93 & 2,38 & 17,23 & 31,95 & 2,25 & 3,10 \\
\hline $\mathrm{T} 14$ & 14,88 & 1,97 & 15,22 & 28,23 & 2,25 & 2,93 \\
\hline $\mathrm{T} 15$ & 11,95 & 4,48 & 23,05 & 24,45 & 3,60 & 3,75 \\
\hline $\mathrm{T} 16$ & 10,58 & 5,75 & 25,38 & 27,00 & 3,85 & 6,53 \\
\hline $\mathrm{T} 17$ & 12,93 & 2,68 & 24,30 & 31,00 & 1,88 & 4,47 \\
\hline $\mathrm{T} 18$ & 13,82 & 5,16 & 26,90 & 30,86 & 2,24 & 6,04 \\
\hline T19 & 12,90 & 2,25 & 18,00 & 27,40 & 1,95 & 2,45 \\
\hline $\mathrm{T} 20$ & 17,04 & 3,14 & 12,88 & 36,30 & 2,64 & 3,90 \\
\hline $\mathrm{T} 21$ & 13,12 & 5,35 & 23,63 & 24,88 & 2,68 & 4,58 \\
\hline $\mathrm{T} 22$ & 9,73 & 7,03 & 27,23 & 25,00 & 3,43 & 5,43 \\
\hline $\mathrm{T} 23$ & 14,37 & 1,80 & 19,63 & 30,87 & 1,73 & 3,60 \\
\hline $\mathrm{T} 24$ & 12,27 & 2,40 & 21,10 & 27,97 & 1,83 & 3,80 \\
\hline $\mathrm{cv} \%$ & 17,45 & 46,16 & 24,65 & 12,24 & 122,57 & 30,01 \\
\hline
\end{tabular}


Tabela 8. Teores foliares médios de micronutrientes, nos diferentes tratamentos

\begin{tabular}{cccccc}
\hline & $\mathbf{B}$ & $\mathbf{C u}$ & $\mathbf{F e}$ & $\mathbf{M n}$ & $\mathbf{Z n}$ \\
\cline { 2 - 6 } TRATAMENTO & & & $\mathbf{m g ~ k g}^{-1}$ & & \\
\hline T1 & 104,83 & 12,83 & 165,17 & 35,67 & 42,33 \\
T2 & 104,33 & 9,83 & 119,50 & 27,50 & 38,33 \\
T3 & 113,62 & 134,62 & 256,67 & 43,97 & 35,85 \\
T4 & 119,80 & 70,40 & 215,80 & 41,80 & 29,00 \\
T5 & 128,80 & 73,80 & 228,80 & 50,80 & 44,60 \\
T6 & 113,17 & 14,17 & 176,67 & 37,67 & 31,33 \\
T7 & 111,20 & 32,00 & 114,80 & 27,80 & 31,20 \\
T8 & 80,17 & 10,50 & 115,83 & 26,50 & 39,33 \\
T9 & 131,00 & 63,33 & 233,67 & 36,00 & 37,67 \\
T10 & 105,83 & 51,50 & 206,17 & 34,50 & 49,33 \\
T11 & 81,33 & 21,00 & 143,33 & 54,00 & 44,67 \\
T12 & 68,17 & 20,33 & 190,00 & 44,33 & 36,17 \\
T13 & 137,25 & 16,25 & 155,00 & 36,25 & 42,75 \\
T14 & 124,67 & 32,50 & 135,50 & 29,00 & 41,50 \\
T15 & 117,25 & 45,00 & 143,00 & 27,50 & 18,00 \\
T16 & 125,25 & 85,50 & 184,25 & 30,75 & 27,75 \\
T17 & 110,83 & 116,50 & 245,00 & 44,00 & 54,00 \\
T18 & 120,60 & 125,20 & 250,40 & 35,20 & 47,80 \\
T19 & 99,50 & 54,00 & 131,50 & 24,50 & 38,50 \\
T20 & 118,80 & 23,00 & 139,40 & 32,60 & 38,80 \\
T21 & 121,33 & 63,00 & 162,50 & 31,17 & 33,17 \\
T22 & 139,00 & 23,67 & 197,00 & 30,33 & 36,67 \\
T23 & 110,33 & 108,67 & 221,33 & 37,67 & 45,67 \\
T24 & 93,33 & 94,67 & 205,67 & 44,00 & 35,00 \\
cv\% & 15,82 & 72,57 & 25,00 & 21,87 & 20,37 \\
cv coeficiente de variação & & & \\
& & & & &
\end{tabular}




\section{A2 - Comportamento dos teores foliares de nutrientes (2 a 2)}

As Figura 22 a 29 apresentam o comportamento dos teores foliares dos macro e micronutrientes ( 2 a 2), dentro das mudas de cada variedade. Em cada figura, a cor do símbolo indica o substrato (vermelho-substrato comercial; verde-mistura; azulvermicomposto). A letra utilizada indica o tipo de inoculação (s-inoculado; n-não inoculado).

Baia

As Figuras 22 e 23, descrevem o comportamento dos teores foliares de macro e micro nutrientes, respectivamente, para a variedade Baia. Ao analisar estas figuras, observa-se a distribuição dos macronutrientes e micronutrientes nos quadros da diagonal. Os quadros que estão abaixo ou acima de cada quadro referente ao macronutriente ou micronutriente representam o eixo " $\mathrm{X}$ ", enquanto os quadros que estão à esquerda ou à direita representam o eixo "Y". Por exemplo, quando se observam os quadros relativos ao Nitrogênio e Fósforo da Figura 22, nota-se uma concentração de pontos vermelhos referentes ao fósforo no lado direito dos quadros acima e abaixo do elemento fósforo e uma concentração de pontos vermelhos na parte superior dos quadros que estão à direita e à esquerda do elemento fósforo, indicando que o substrato comercial (vermelho) proporcionou maiores teores foliares de fósforo nas plantas cultivadas neste substrato. Enquanto para nitrogênio não existe uma tendência bem definida, quanto à distribuição dos pontos, mostrando que não houve um efeito pronunciado para a absorção de nitrogênio nos diferentes tratamentos.

A Figura 22 representa o comportamento da concentração foliar de macronutrienes, nos diferentes tratamentos para a variedade Baia. Segue na descrição abaixo, as principais observações para cada macronutriente. 
Nitrogênio: para este elemento, não houve uma tendência significativa de concentração foliar, não teve influência de substrato e inoculação;

Fósforo: existe uma tendência de maior concentração foliar de fósforo nas folhas das plantas que foram cultivadas no substrato comercial;

Potássio: nas plantas cultivadas no substrato comercial, ocorre uma tendência de acumular mais potássio em suas folhas;

Cálcio: para este elemento não é observada nenhuma tendência de concentração foliar, não havendo um efeito significativo de substrato e inoculação;

Magnésio: observa-se uma tendência de maiores concentrações foliar de magnésio no substrato comercial e sob efeito de inoculação com Xylella fastidiosa;

Enxofre: houve maior concentração foliar de enxofre nas plantas cultivadas no substrato comercial. 
Baia
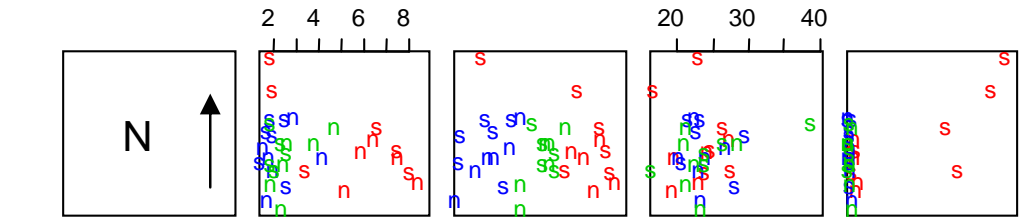

$\begin{array}{llll}2 & 4 & 6 & 8\end{array}$
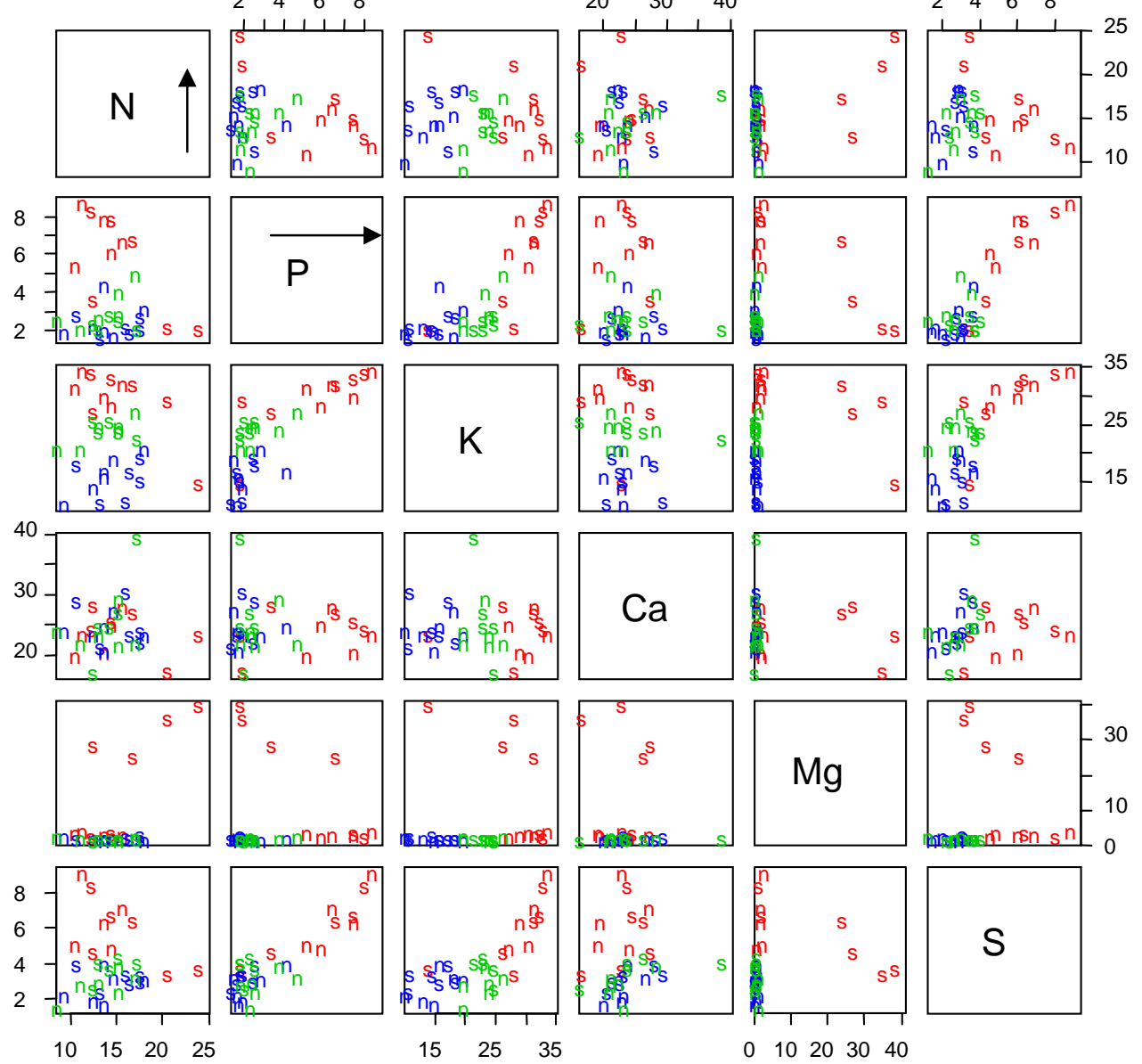

S

Figura 22 - Relação entre teor foliar de macronutrientes na variedade Baia, por substrato e tipo de inoculação (veja texto para detalhes)

A Figura 23, representa o comportamento dos teores foliares de micronutrientes na variedade Baia, observam-se os seguintes fatos:

Boro: não é observada uma tendência significativa para maiores concentrações foliar de boro nos diferentes substratos e sob efeito de inoculação ou não; 
Cobre: para este elemento a tendência é de maior concentração nos tratamentos com substrato comercial seguido da mistura de substrato comercial mais vermicomposto;

Ferro: neste caso a tendência é que as maiores concentrações estão nos tratamentos com substrato comercial seguido do tratamento com mistura de substrato comercial mais vermicomposto;

Manganês: também ocorre a tendência de maior concentração nos tratamentos com substrato comercial e na mistura de substrato comercial mais vermicomposto;

Zinco: para este elemento não é observada uma forte tendência de concentração do nutriente, para os diversos tratamentos. 
Baia

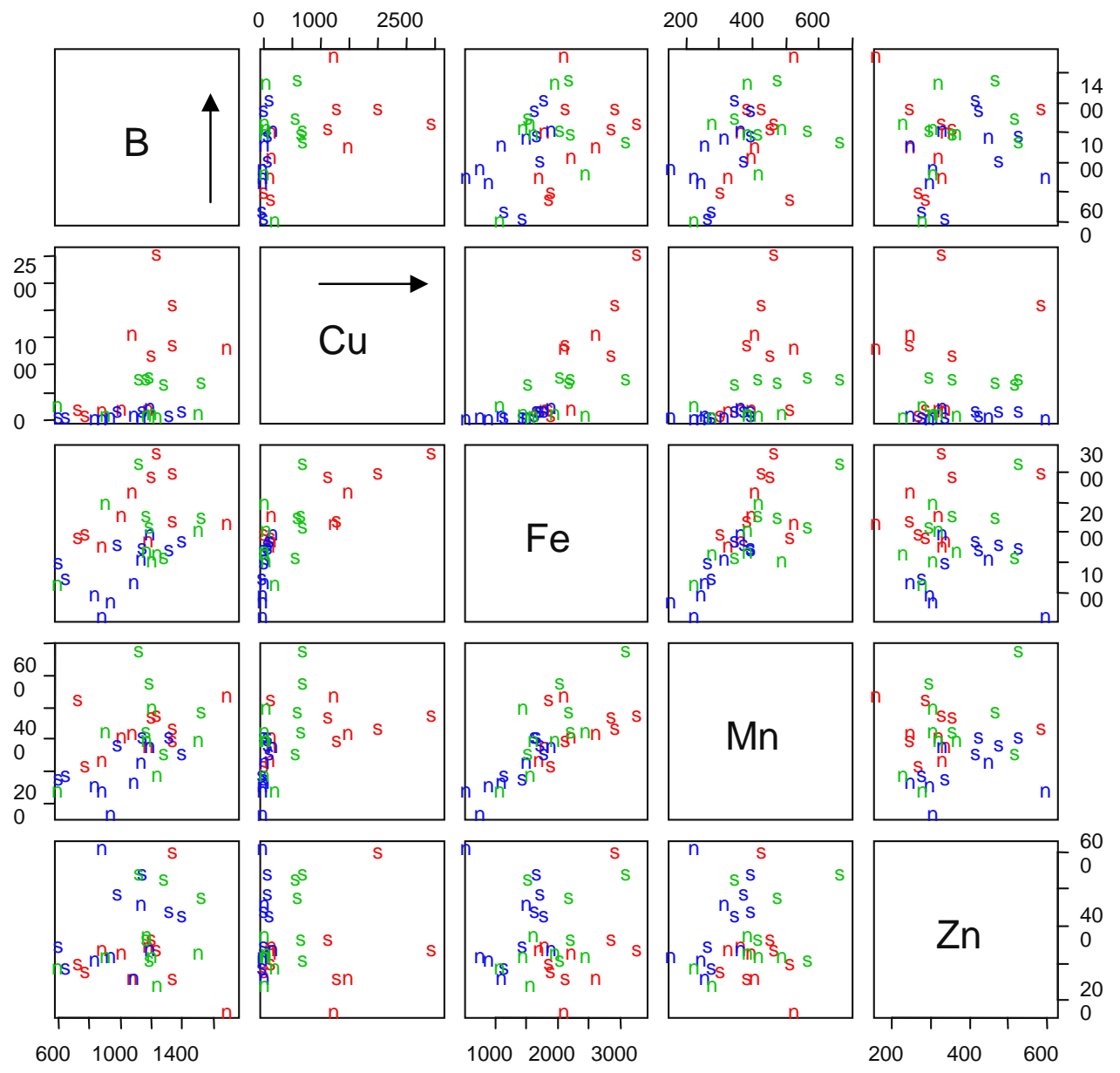

Figura 23. Relação entre teor foliar de micronutrientes na variedade Baia, por substrato e tipo de inoculação (veja texto para detalhes)

\section{Escape}

As Figuras 24 e 25, descrevem o comportamento dos teores foliares de macro e micro nutrientes, respectivamente, para a variedade Escape. 
Na Figura 24 representa o comportamento dos teores foliares de macronutrientes na variedade Escape, observam-se os seguintes fatos:

Nitrogênio: para este elemento não se observa uma tendência de ocorrência de maiores concentrações nos tratamentos em questão;

Fósforo: neste caso se observa a tendência de menores concentrações no tratamento com substrato a base de vermicomposto, com interferência negativa aparente da inoculação;

Potássio: ocorre a tendência de ocorrer maior concentração para o tratamento com substrato comercial e na mistura de substrato comercial com vermicomposto;

Cálcio: não é observada uma forte tendência da concentração foliar deste nutriente;

Magnésio: a tendência observada é a ocorrência de maiores concentrações no tratamento com substrato comercial;

Enxofre: não se observa uma tendência de maiores concentrações deste elemento nos diferentes tratamentos. 


\section{Escape}

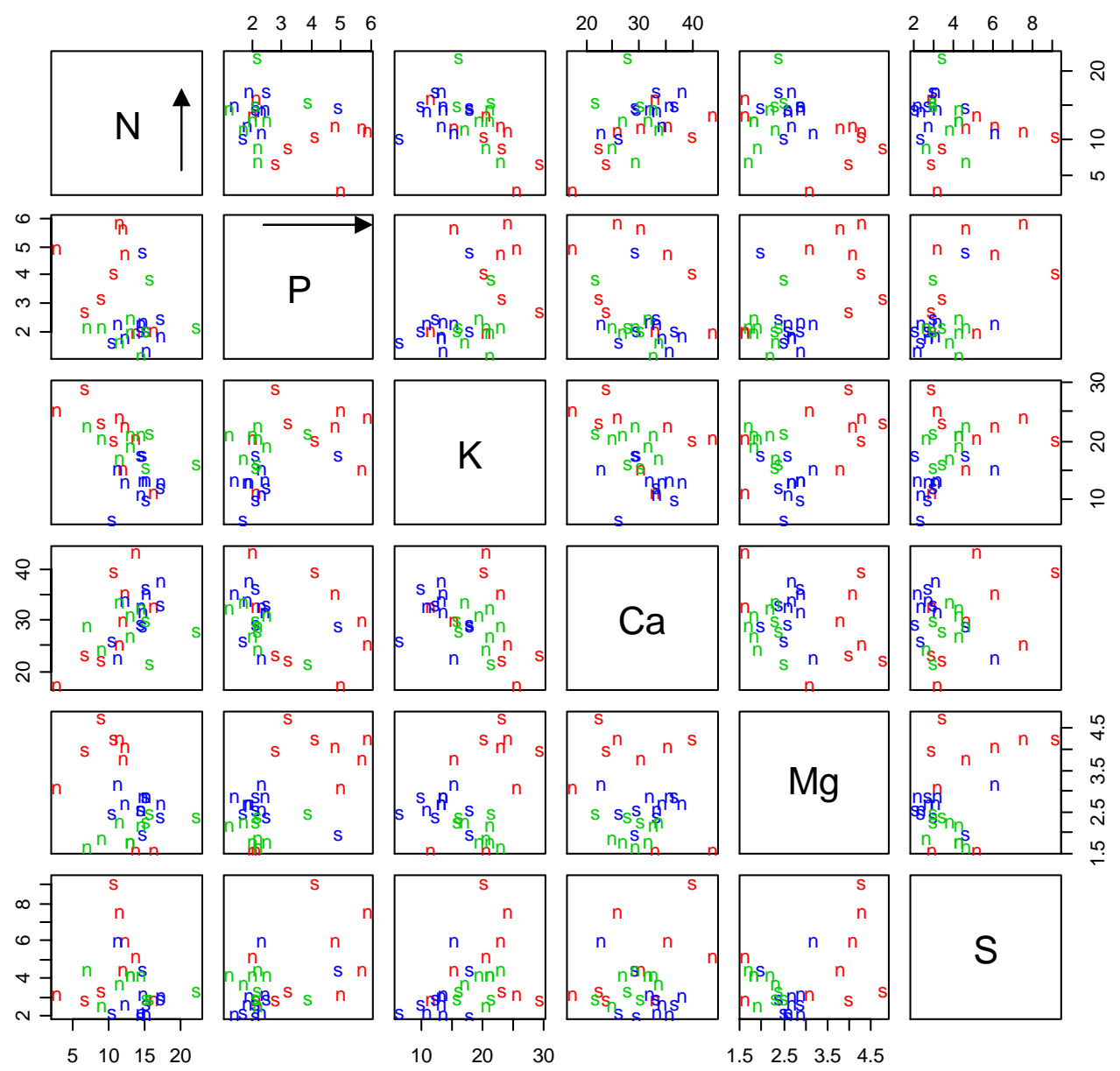

Figura 24 - Relação entre teor foliar de macronutrientes na variedade Escape, por substrato e tipo de inoculação (veja texto para detalhes).

A Figura 25, representa o comportamento dos teores foliares de micronutrientes na variedade Escape, com as seguintes observações:

Boro: não se observa uma tendência de concentração foliar do elemento para os diversos tratamentos; 
Cobre: existe uma tendência de ocorrer maiores concentrações foliares nos tratamentos com substrato comercial e na mistura de substrato comercial com vermicomposto;

Ferro: para este elemento não é observada uma tendência forte de concentração do nutriente, para os diversos tratamentos;

Manganês: existe a tendência de maior concentração nos tratamentos com substrato comercial e na mistura de substrato comercial mais vermicomposto;

Zinco: não se observa uma tendência forte de concentração do nutriente zinco, para os diversos tratamentos. 


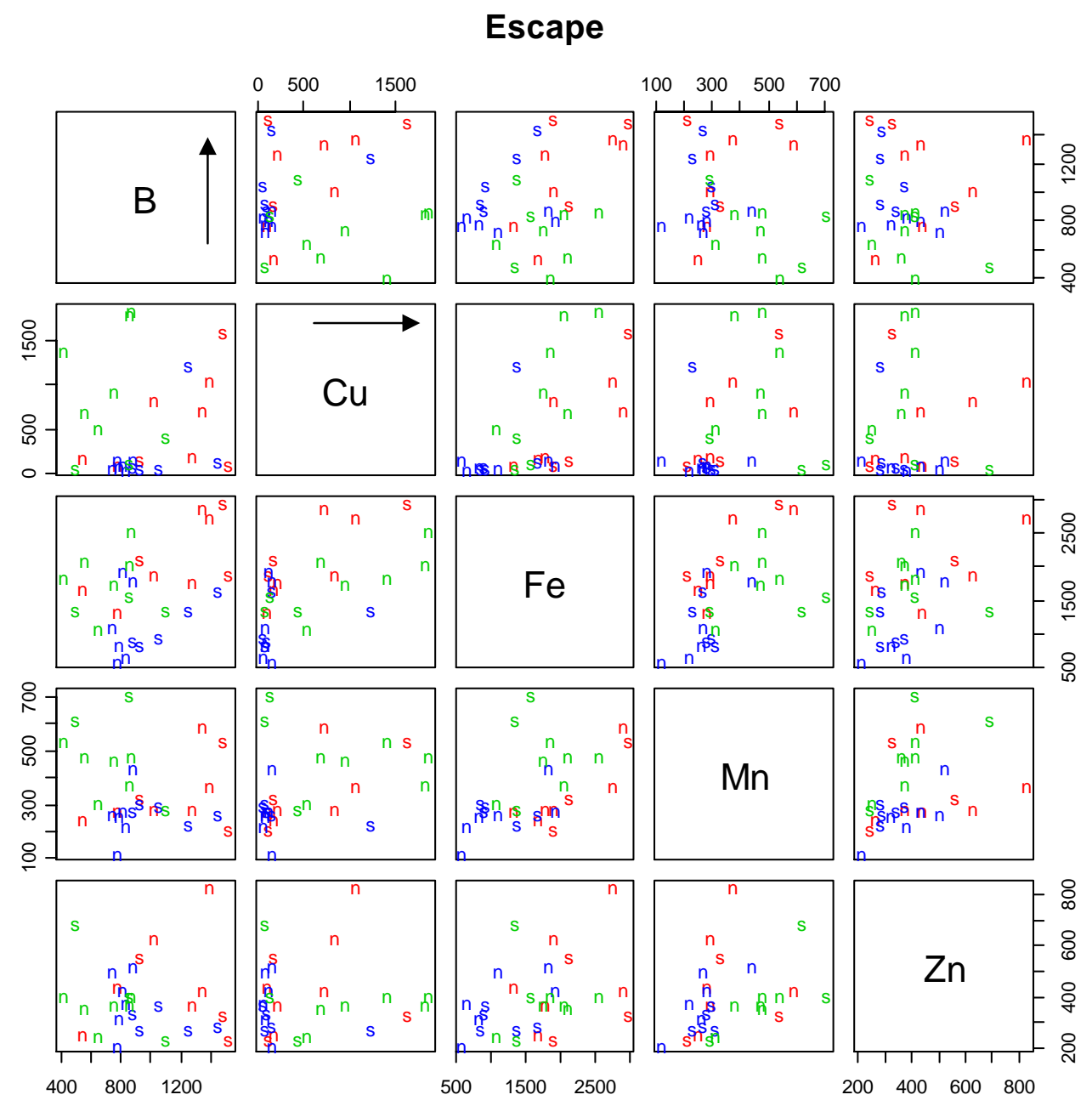

Figura 25. Relação entre teor foliar de micronutrientes na variedade Escape, por substrato e tipo de inoculação (veja texto para detalhes)

\section{Natal}

As Figuras 26 e 27, descrevem o comportamento dos teores foliares de macro e micro nutrientes, respectivamente, para a variedade Natal.

Na Figura 26 está representado o comportamento das concentrações foliares de macronutrientes para a variedade Natal nos diferentes tratamentos. 
Nitrogênio: para este elemento não existe uma tendência evidente, de maior concentração foliar nos diversos tratamentos;

Fósforo: a tendência observada é que ocorre uma concentração foliar maior nos tratamentos com substrato comercial e a mistura de substrato comercial com vermicomposto;

Potássio: para Potássio observa-se a mesma tendência do Fósforo, com maiores concentrações nos tratamentos com substrato comercial e a mistura de substrato comercial com vermicomposto;

Cálcio: para este elemento não existe uma tendência notável de concentração foliar para os diversos tratamentos;

Magnésio: neste caso a tendência de maiores concentrações foliares de magnésio, ocorre no tratamento com substrato comercial;

Enxofre: observa-se a tendência de maiores concentrações foliares nos tratamentos com substrato comercial e a mistura do substrato comercial com o vermicomposto. 
Natal

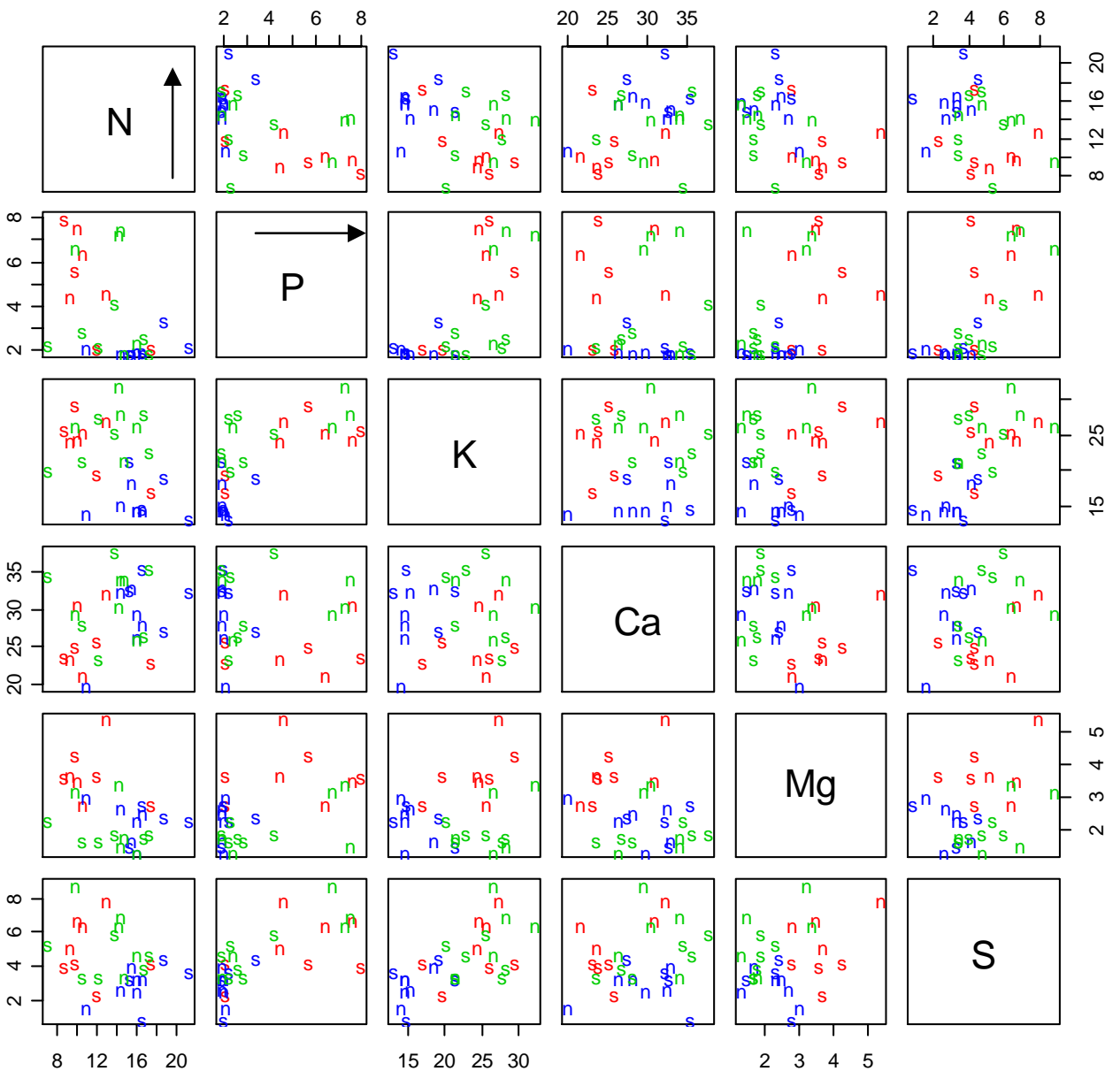

Figura 26 - Relação entre teor foliar de macronutrientes na variedade Natal, por substrato e tipo de inoculação (veja texto para detalhes)

A Figura 27, que representa o comportamento dos teores foliares de micronutrientes na variedade Natal, observa-se os seguintes fatos:

Boro: não se observa tendências de maiores concentrações foliares nos diversos tratamentos; 
Cobre: as maiores concentrações foliares estão presentes no tratamento com mistura de substratos (substrato comercial + vermicomposto);

Ferro: observa-se a tendência de ocorrer maiores concentrações foliares no tratamento com mistura de substratos (substrato comercial + vermicomposto);

Manganês: não existe uma tendência definida de maiores concentrações nos diferentes tratamentos;

Zinco: a tendência é a ocorrência de maiores concentrações foliares no tratamento com mistura de substratos (substrato comercial + vermicomposto) no substrato a base de vermicomposto. 
Natal

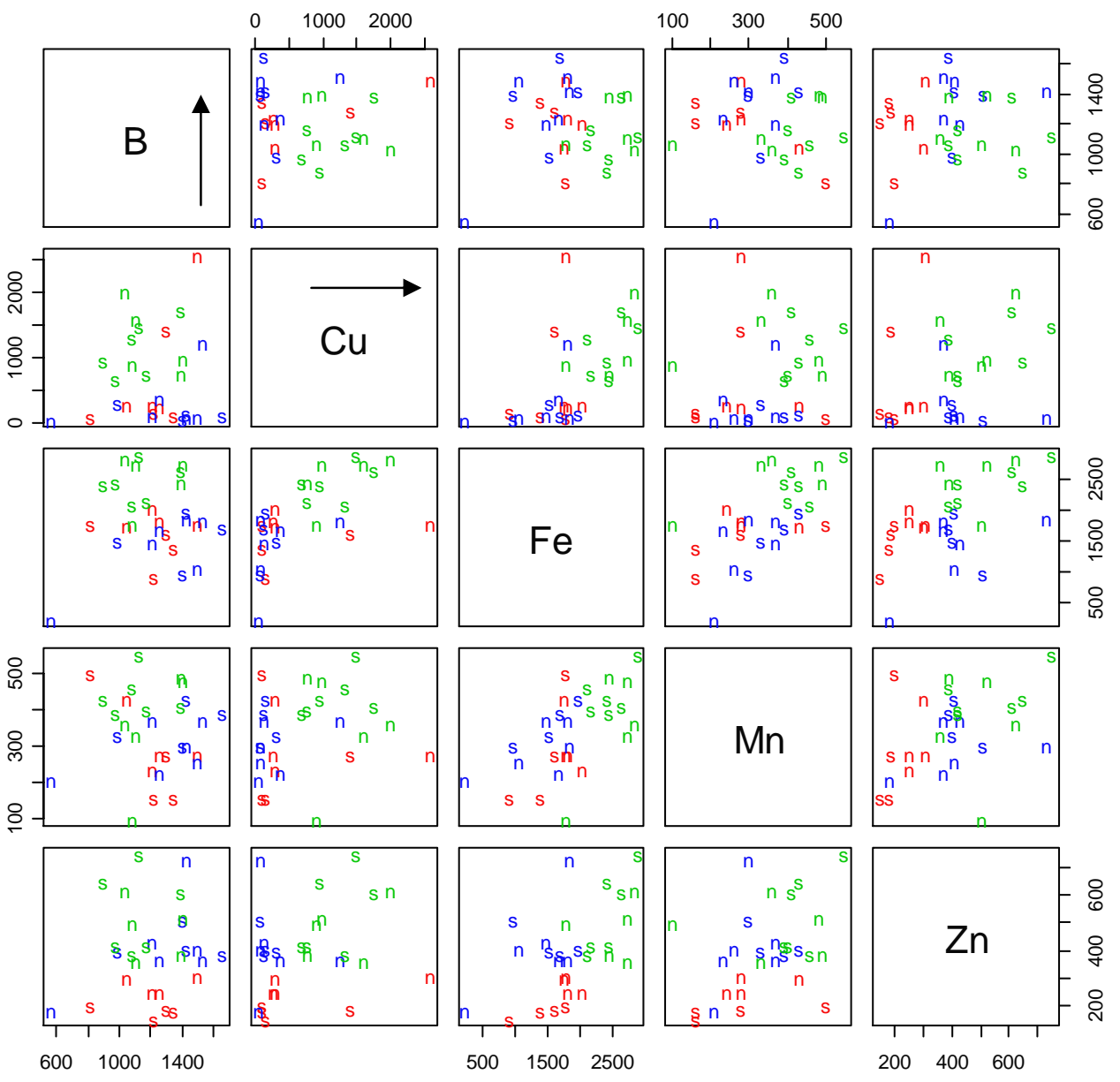

Figura 27 - Relação entre teor foliar de micronutrientes na variedade Natal, por substrato e tipo de inoculação (veja texto para detalhes)

Pêra

As Figuras 28 e 29, descrevem o comportamento dos teores foliares de macro e micro nutrientes, respectivamente, para a variedade Pêra.

$\mathrm{Na}$ Figura 28, representa o comportamento das concentrações foliares de macronutrientes na variedade Pêra. 
Nitrogênio: para este elemento não existe uma tendência evidente, de maior concentração foliar nos diversos tratamentos;

Fósforo: a tendência observada é que ocorre uma concentração foliar maior nos tratamentos com substrato comercial;

Potássio: existe uma tendência aparente, de ocorrer maior concentração no tratamento com substrato comercial;

Cálcio: para este elemento não existe uma tendência forte para concentração foliar nos diferentes tratamentos;

Magnésio: as maiores concentrações foliares tendem a ocorrer no tratamento com substrato comercial;

Enxofre: para este elemento existe uma tendência das maiores concentrações ocorrem no tratamento com substrato comercial. 


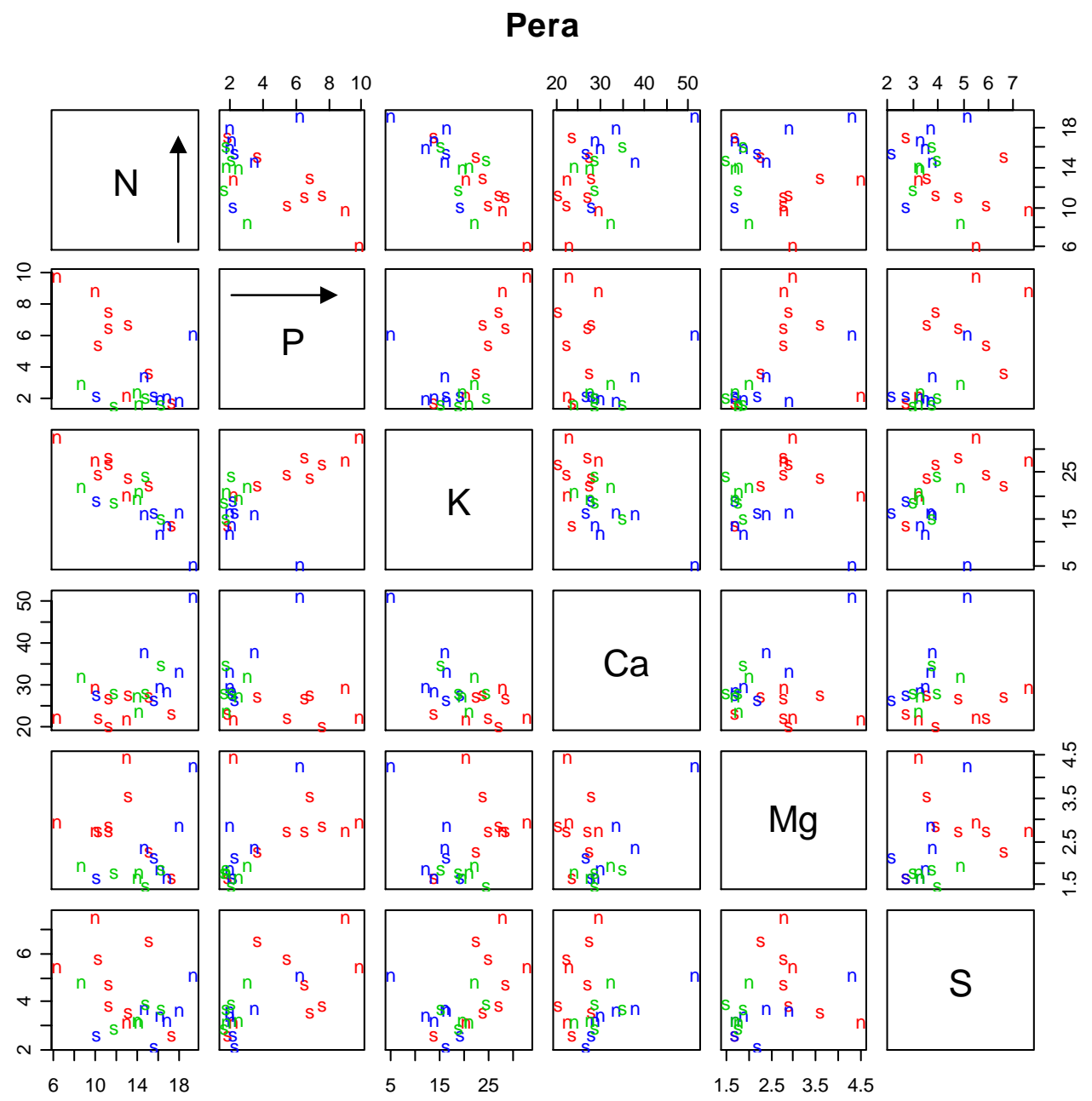

Figura 28 - Relação entre teor foliar de macronutrientes na variedade Pêra, por substrato e tipo de inoculação (veja texto para detalhes)

A Figura 29, representa o comportamento das concentrações foliares de micronutrientes na variedade Pêra, observa-se os seguintes fatos:

Boro: não se observa uma tendência notável para a concentração foliar nos diferentes tratamentos; 
Cobre: a maior tendência é observada no tratamento com a mistura de substratos ( substrato comercial + vermicomposto);

Ferro: não se observa uma tendência notável para a concentração foliar nos diferentes tratamentos;

Manganês: para este elemento não se observa uma forte tendência de concentração entre os diversos tratamentos;

Zinco: não se observa uma tendência notável para a concentração foliar nos diferentes tratamentos. 
Pera

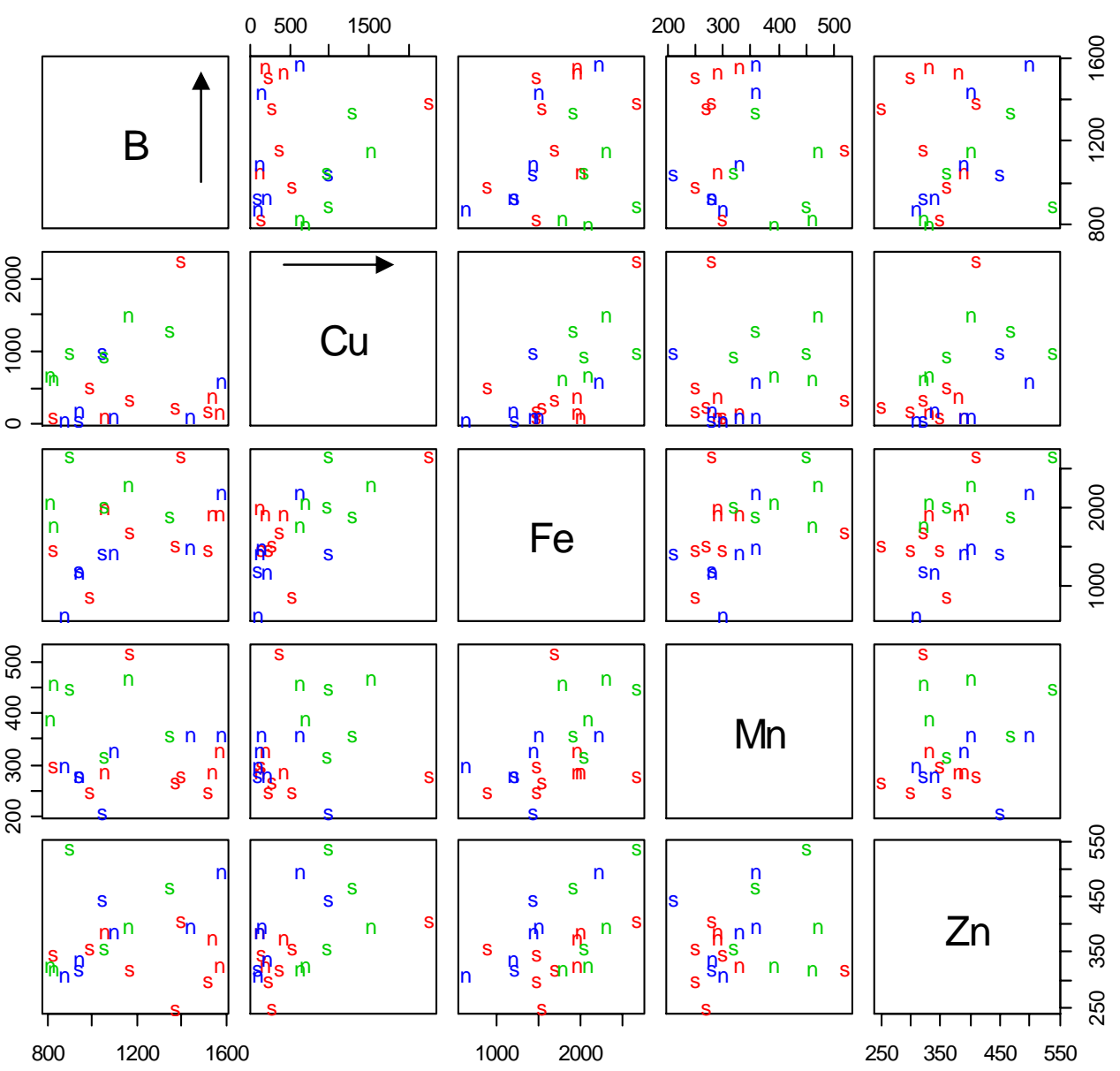

Figura 29 - Relação entre teores foliares de micronutrientes na variedade Pera, por substrato e tipo de inoculação (veja texto para detalhes) 
Tabela 9. Efeito dos tratamentos nos diferentes parâmetros analisados

\section{Tratamentos}

\begin{tabular}{ccccccc} 
Parâmetros & Vr. & Inc & Sub & Vr.:Inc & Vr.:Sub Inc:Sub & Vr.:Inc:Sub \\
\hline $\mathrm{N}$ & & $*$ & $* * *$ & & & $*$ \\
$\mathrm{P}$ & & $* * *$ & & & & \\
$\mathrm{~K}$ & $* * *$ & & $* * *$ & & & \\
$\mathrm{Ca}$ & $* * *$ & $*$ & & & \\
$\mathrm{Mg}$ & & & $* * *$ & $*$ & & \\
$\mathrm{~S}$ & & & $* * *$ & & $*$ \\
$\mathrm{~B}$ & $* * *$ & & $*$ & & & \\
$\mathrm{Cu}$ & & & $* * *$ & & $*$ & \\
$\mathrm{Fe}$ & & $* * *$ & $*$ & $* *$ & \\
$\mathrm{Mn}$ & & $* * *$ & & \\
$\mathrm{Zn}$ & & $* *$ & & \\
\hline
\end{tabular}

***, ** $\mathrm{e}^{*}$ - Teste de Tukey, significativo a $0,1 \%, 1 \%$ e $5 \%$ respectivamente

Vr. = Variedade $\quad-\quad$ Inc $=$ Inoculação com Xylella fastidiosa $\quad-\quad$ Sub $=$ Substrato

Vr.:Inc = interação variedade e inoculação - Vr.:Sub = interação variedade e substrato

Inc:Sub = interação inoculação e substrato - Vr.:Inc:Sub = interação variedade, inoculação e substrato 


\section{REFERÊNCIAS BIBLIOGRÁFICAS}

ABAD, M.; NOGUERA, P. Substratos para el cultivo sin suelo y fertirrigación. In: CADAHIA, C. (Coord.) Fertirrigación: cultivos horticolas y ornamentals. Madrid: Mundial-Prensa, 1988. p.287-342.

ALBANELL, E.; PLAIXATS, J.; CABRERO, T. Chemical changes during vermicomposting (Eisenia fetida) of sheep manure mixed with cotton industrial wastes. Biology and Fertility of Soils, v.6, p.266-269, 1988.

ALMEIDA, R.P.P.; PEREIRA, E.F.; PURCELL, A.H.; LOPES, J.R.S. Multiplication and moviment of a citrus strain of Xylella fastidiosa within sweet orange. Plant Diseases, v.85, n.4, p.382-386, 2001.

ALVES, W.L.; PASSONI, A.A. Composto e vermicomposto de lixo urbano na produção de mudas de oiti (Licania tomentosa (BENTH)) para arborização. Pesquisa Agropecuária Brasileira, v.32, n.10. p.1053-1058, 1997.

ANTONIOLLI, Z.I.; GIRACCA, E.M.N.; BAUER, C. Vermicompostagem. Santa Maria: UFSC, Centro de Ciências Rurais, 1995. 3p. (Informe Técnico, 2). 
AQUINO, A.M.; ALMEIDA, D.L.; DE-POLLI; H. Dinâmica da liberação de nutrientes dos vermicompostos utilizando milho como planta teste. In: REUNIÃO BRASILEIRA DE FERTILIDADE DO SOLO E NUTRIÇÃO MINERAL DE PLANTAS, 21., Petrolina, 1994. Resumos. Petrolina: SBCS; EMBRAPA, CPATSA. 1994. p.194-195.

ASSOCIAÇÃO DOS CITRICULTRORES DO ESTADO DE SÃO PAULO. ASSOCITRUS. http://www.associtrus.com.br (09 jan.2004).

ASSOCIAÇÃO PAULISTA DE VIVEIROS CERTIFICADOS DE CITROS VIVECITRUS. Vivecitrus de olho no futuro. Informativo, v.2, n.11, set. 2003.

ATIYEH, R.M.; ARANCON, N.Q.; EDWARDS, C.A.; METZGER, J.D. Influence of earthworm-processed on growth and yield of greenhouse tomatos. Bioresourse Technology, v.75, p.175-180, 2000.

ATIYEH, R.M.; LEE, S.; EDWARDS, C.A.; ARANCON, N.Q.; METZGER, J.D. The influence of humic acids derived from earthworm-processed organic wastes on plant growth. Bioresourse Technology, v.84, p.7-14, 2002.

BAYLIS, G.T.S. The magnolioid mycorrhiza and mycotrophy in root systems derived from it. In: SANDERS, F.E.; MOSSE, B; TINKER, P.B (Ed.) Endomycorrhizas. New York: Academic Press, 1975. p.373-390.

BERETTA, M.J.; HARAKAVA, R.; CHAGAS, C.M.; DERRICK, K.S.; BARTHE, G.A.; CECCARDI, T.L.; LEE, R.F.; PARADELA FILHO, O.; SUGIMORI. M.H.; RIBEIRO, I.J.A. First report of Xylella fastidiosa in coffee. Plant Disease, v.80, n.7, p.821, 1996. 
BLOM, T.J. Working with soilles mixes, a guide to the different materials, characteristics and uses of soiless mixes. Florists Review, v.173, n.4480, p.29-34, 1983.

BRUNDRETT, M.C.; ABBOT, L.K. Mycorrhizas en natural ecosystems. Advances in Ecological Research, v.21, p.171-313, 1991.

CARVALHO, S.A.; SOUZA, M. Escaldadura das folhas da ameixa: Provável responsável pelo declínio da cultura no sul do Estado de Minas Gerais. Pesquisa Agropecuária Brasileira, v.26, n.11/12, p.2015-2020, 1991.

COUTINHO, C.J.; CARVALHO, C.M. O uso da vermiculita na produção de mudas florestais. In: ENCONTRO NACIONAL DE REFLORESTADORES, 7., Curitiba, 1983. Anais. Curitiba, 1983. p.54-63.

CRESTE, J.E.; NAKAGAWA, J. Diagnose foliar no monitoramento da adubação de citros. In: SIMPÓSIO SOBRE FISIOLOGIA, NUTRIÇÃO, ADUBAÇÃO E MANEJO PARA PRODUÇÃO SUSTENTÁVEL DOS CITROS. Piracicaba, 2000. Piracicaba: Potafos, 2000. p. 23-27.

DAVIS, M.J.; PURCELL, A.H.; THOMSON, S.V.Pierce's disease of grapevines: isolation of the causal bacterium. Science, v.199, p.75-77, 1978.

DAVIS, R.M.; MENGE, J.A. Influence of Glomus fasciculatus and soil phosphorus on phytophthora root of citrus. Phytopathology, v.70, n.5, p.447-452, 1980.

DONADIO, L.C. Propagação dos citros. In: ENCONTRO PARANAENSE DE CITRICULTURA, 1., Londrina, 1986. Anais. Londrina: IAPAR, 1986. p.83-94. 
DONADIO, L.C.; FIGUEIREDO, J.O.; PIO, R.M. Variedades cítricas brasileiras. Jaboticabal: FUNEP, 1995. 228p.

DONADIO, L.C.; MOREIRA, C.S. Clorose variegada dos citros, Jaboticabal: FUNDECITRUS; Estação Experimental de Citricultura de Bebedouro, 1997. 27p. (Edição Comemorativa).

FUNDECITRUS. Fundecitrus. Estatísticas - CVC. http://www.fundecitrus.com.br/ escr.html (05 nov.2003).

GONÇALVES, A.L. Substratos para produção de mudas de plantas ornamentais. In: MINAMI, K. (Ed.). Produção de mudas de alta qualidade em horticultura. São Paulo: T.A. Queiroz, 1995. p.108-118.

GONÇALVES, J.L. de M.; POGGIANI, F. Substrato para produção de mudas.(Compact disc). In: SOLO SUELO - CONGRESSO LATINO AMERICANO DE CIÊNCIA DO SOLO, 13., Águas de Lindóia, 1996. Resumos expandidos. Águas de Lidóia: SLCS; SBCS; ESALQ/USP, CEA; SBM, 1996.

GRAPPELLI, A.; GALLI, E.; TOMATI, U. Earthworm casting effect on Agaricus bisporus fructification. Agrochimica, v.21, p.457-462,1987.

HARLEY, J.L.; HARLEY, E.L. A check-list of mycorrhiza in the British flora. New Phytologisty, v.105.p.1-102, 1987. Supplement

HARLEY, J.L.; SMITH, S.E. Mycorrhizal symbiosis. New York: Academic Press, 1983. 286p. 
HARTMANN, H.T.; KESTER, D.E. Plant propagation: principles and practices. 3.ed. New Jersey: Prentice-Hall, 1975. 661p.

IHAKA, R.; GENTLEMAN, R. A language for data analysis and graphics. Journal of Computational and Graphical Statistics, v.5, n.3, p.299-314, 1996.

INSTITUTO BRASILEIRO DO CAFÉ. Cultura do cafeeiro no Brasil: manual de recomendações. 5 ed. Rio de Janeiro: IBC, 1985. 312p. .

KELMAN, A.; COOK, R.J. Plant pathology in the People's Republic of China. Annual Review of Phytopathology, v.15, p.409-429, 1977.

KIEHL, J.E. Fertilizantes orgânicos. Piracicaba: Ceres, 1985. 492p.

KLEINSCHMIDT, G.D.; GERDEMANN, J.W. Stunting of citrus seedlings in fumigate nursery soils related to the absence of endomycorrhizal. Phytopathology, v.62, p.1447-1453, 1972.

LACAVA, P.T. Isolamento, caracterização genética por RAPD e resistência a antibióticos em Xylella fastidiosa. Piracicaba, 2000. 108p. Dissertação (Mestrado) - Escola Superior de Agricultura “Luiz de Queiroz”, Universidade de São Paulo.

LAMBAIS, M.R.; GOLDMAN, M.H.S.; CAMARGO, L.E.A.; GOLDMAN, G.H. A genomic approach to the understanding of Xylella fastidiosa pathogenicity. Current Opinion in Microbiology, v.3, p.459-462, 2000.

LARANJEIRA, F.F.; PALAZZO, D. Determinação preliminar dos efeitos da Clorose Variegada dos Citros em características físico-quimicas de frutos de laranja Natal. Fitopatologia Brasileira, v.19, p.309, 1994. Suplemento. 
LARANJEIRA, F.F.; PALAZZO, D.A. Danos qualitativos à produção de laranja Natal causados pela clorose variegada dos citros. Laranja, v.20, n.1, p.55-76, 1999.

LARANJEIRA, F.F.; POMPEU JUNIOR, J. Comportamento de quinze cultivares de laranja Doce afetada pela clorose variegada dos citros. Laranja, v.23, n.2, p.387400, 2002.

LARANJEIRA, F.F.; POMPEU JUNIOR, J.; HARAKAVA, R. Seleção de variedades resistentes e/ ou tolerantes à Clorose Variegada dos Citros (CVC). Fitopatologia Brasileira, v.20, p.324, 1995. Suplemento.

LARANJEIRA, F.F.; POMPEU JUNIOR, J.; HARAKAVA, R.; FIGUEIREDO, J.O.; CARVALHO, S.A.; COLETTA FILHO, H.D. Cultivares e espécies cítricas hospedeiras de Xylella fastidiosa em condições de campo. Fitopatologia Brasileira, v.23, n.2, p.147-154, 1998.

LEE, R.F.; DERRICK, K.S.; BERETTA, M.J.G.;CHAGAS, C.M.; ROSSETTI, V. Citrus Variegated chlorosis a new destructive disease of citrus in Brazil. Citrus Industry, v.72, n.15, p.10-13, 1991.

LEE, R.F.; BERETTA, M.J.G.; DERRICK, K.S.; HOOKER, M.E. Development of a serological assay for citrus variegated chlorosis - a new disease of citrus In Brazil. Proceedings of Florida State Horticultural Society, v.105, p.32-34, 1992.

LEITE JUNIOR, R.P.; LEITE, R.M.V.B.C. Associação de Xylella fastidiosa com clorose variegada dos citros. Summa Phytopathologica, v.17, p.7, 1991.

LONGO, A.D. Minhoca de fertilizadora do solo a fonte alimentar. São Paulo: Ed. ICONE, 1987. 79p. 
LOPES, E.S.; OLIVEIRA, E.; DIAS, R.; SCHENCK, N.C. Occurrence and distribution of vesicular -arbuscular Mycorrhizal Fungi in Coffee (Coffea arabica L.) plantations in central São Paulo state, Brazil. Turrialba, v.33, n.4, p.417-422, 1978.

MACHADO, M.A.; SILVÉRIO, J.L.; BAPTISTA, C.R.; CRISTOFANI, M.; SOBRINHO, J.T. Avaliação de transmissão e seleção de variedades à clorose variegada dos citros (CVC). Laranja, v.13, n.2, p.515-531, 1992.

MACHADO, M.A.; SILVÉRIO, J.L.; BAPTISTA, C.R.; LARANJEIRA, F.F.; BERETTA, M.J.G. Transmissão e seleção de espécies e variedades a CVC(II). Laranja, v.14, n.1, p.167-176, 1993.

MALAVOLTA, E.; VITTI, G.C.; OLIVEIRA, S.A. Avaliação do estado nutricional das plantas princípios e aplicações. Piracicaba: Potafos, 1997. 319p.

MALAVOLTA, E.; PRATES, H.S.; VITTI, G.C.; PINTO, W.B.S. Novas observações sobre o "Amarelinho" ou Clorose Variegada dos Citros. Laranja, v.14, n.1, p.177200, 1993.

MARSCHNER, H. Mineral nutrition of higher plants. 2.ed. London: Academic Press, 1995. 889p.

MARX, D.H.; BRYAN, W.C.; CAMPBELL, W.A. Effect of endomycorrhizae formed by Endogone mosseae on growth of citrus. Mycologia, v.63, p.1222-1226, 1971.

MATTOS JUNIOR, D.; QUAGGIO, J.A.; CARVALHO, S.A.; ABREU, M.F. Substratos para produção de mudas cítricas em recipientes: Caracterização da toxidade de boro. Laranja, v.16, n.1, p.255-262, 1995. 
MENGE, J.A.; JARRELL, W.M.; LABANAUSKAS, C.K.; OJALA, J.C.; HUSZAR, C.; JOHNSON, E.L.V. Predicting Mycorrhizal dependency of Troyer Citrange on Glomus fasciculatus in Califórnia citrus soils and nursery mixes. Soil Science Society of American Journal, v.46, p.762-768, 1982.

MIZUBUTI, E.S.G.; MATSUOKA, K.; PARIZZI, P. Associação de bactéria tipo Xylella em laranjeiras com sintomas de Clorose Variegada dos na região da Zona da Mata de Minas Gerais. Fitopatologia Brasileira, v.19, n.2, p.241-244, 1994.

MOREIRA, C.S.; PIO, R.M. Melhoramento de citros. In: RODRIGUES, O.; VIEGAS, F.; POMPEU JUNIOR, J.; AMARO, A.A. Citricultura brasileira. 2 ed. Campinas: Fundação Cargill, 1991. p.116-154.

MOREIRA, F.M.S.; SIQUEIRA, J.O. Microbiologia e bioquímica do solo. Lavras: Editora UFLA, 2002. 626p.

MOREIRA, C.S.; MÜLLER, G.W.; GRAVENA, S. A citricultura na China. Laranja, v.10, n.1, p.107-122, 1989.

MOSS, G.I. Propagation of citrus for future plantings. In: INTERNATIONAL SOCIETY OF CITRICULTURE, Lake Alfred, 1978. Proceedings. Lake Alfred: ICS, 1978. 124p.

MOSSE, B. The regular germination of resting spores and some observations on the growth requirements of an Endogone sp. Causing vesicular-arbuscular mycorrhiza. Transactions of the British Mycological Society, v.42, p.273-285, 1959.

MOSSE, B. The influence of soil type and Endogene strain on the growth of mycorrhizal plants in phosphate deficient soil. Review Ecology Biology Zoology, v.9, p.529-537, 1972. 
NEMEC, S. Responses of six citrus rootstocks to three Species of Glomus, a mycorrhizal fungus. Proceedings of the Florida State Horticultural Society, v.91, p.10-14, 1978.

NEMEC, S.; PATTERSON, M. Comparison of techniques to inoculate citrus in the field in Florida. The Citrus Industry, v.60, n.7, p.31-40, 1979.

NEVES, E.M. Economia de produção citrícola e efeitos alocativos. Preços Agrícolas, v.14,n.162, p.9-12, 2000.

O'BANNON, J.H.; INSERRA, R.N.; NEMEC, S.; VOVLAS, N. The influence of Glomus mosseae on Tylenchulus semipenetrans infected and unifected Citrus limon seedlings. Journal of Nematology, v.11, n.3, p.247-250, 1979.

PALAZZO, D.A.; CARVALHO, M.L.V. Estimativas de perdas em laranja Natal, por clorose variegada dos citros (CVC), nas colheitas de 1991/92, em Colina, SP. Fitopatologia Brasileira, v.18, p.295, 1993. Suplemento.

PARADELLA FILHO, O.; SUGIMORI, M.H.; RIBEIRO, I.J.A.; MACHADO, M.A.; LARANJEIRA, F.F.; GARCIA JUNIOR, A.; BERETTA, M.J.G.; HARAKAWA, R.; RODRIGUES NETO, J.; BERIAM, L.O.S. Primeira constatação em cafeeiro no Brasil, da Xylella fastidiosa causadora da Clorose Variegada dos Citros. Laranja, v.16, n.2, p.135-136, 1995.

PEDRO JUNIOR, M.J.; MELLO, M.H.A.; PEZZOPANA, J.E.M. Caracterização agroclimática da microbacia: Alto curso do Ribeirão São Domingos. Campinas: Instituto Agronômico., 1994. 27p. (Boletim Técnico, 150). 
PEIXOTO, J.R. Efeito da matéria orgânica, do superfosfato simples e do cloreto de potássio na formação de mudas do maracujazeiro amarelo (Passiflora edulis f. Flavicarpa Deneger). Lavras, 1986. 101p. Dissertação (Mestrado) - Escola Superior de Agricultura de Lavras.

PEREIRA, A.V. Efeito de tipos e tamanhos de sacos plásticos sobre o desenvolvimento de porta-enxertos de seringueira (Hevea sp.) Lavras, 1983. 44p. Dissertação (Mestrado) - Escola Superior de Agricultura de Lavras.

POMPEU JUNIOR, J. Porta-enxertos para citrus. In: RODRIGUEZ, O.; VIEGAS, F.C.P. Citricultura brasileira. Campinas: Fundação Cargill, 1980. p.279-296.

PONS, A.L. Fontes e usos da matéria orgânica. IPAGRO Informa, n.26, p.111-147, 1983.

PRIMAVESI, A.M.; COVOLO, G. Comparação entre atividade dos cupins e minhocas com relação a estrutura e nutrientes do solo. In: CONGRESSO LATINO AMERICANO DE BIOLOGIA DO SOLO: Progressos em biodinâmica e produtividade do solo, 2., Santa Maria, 1968. Anais. Santa Maria, 1968. p.149154.

QUAGGIO, J.A. Análise de solo para citros: métodos e critérios para a interpretação de resultados. In: SEMINÁRIO INTERNACIONAL DE CITROS - NUTRIÇÃO E ADUBAÇÃO, Campinas, 1996. Anais. Campinas: Fundação Cargill, 1996. p.95113.

QUEIROZ-VOLTAN, R.B.; PARADELLA FILHO, O. Caracterização de estruturas anatômicas de citros infectados com Xylella fastidiosa. Laranja, v.20, n.1, p.55-76, 1999. 
RHODES, L.H.; GERDEMANN, J.W. Nutrient translocation in vesicular-arbuscular mycorrhizae. In: COOK, C.B.; PAPAAS, W.; RUDOLPH, E.D. Cellular interactions in symbiosis and parasitism. Columbs: Ohio State University Press, 1980. p.173-195.

RIVIERI, L.M. Importance des caracteristiques physiques dans le choix des substrats pour les cultures hors sol. Revue Horticole, v.209, p.23-27, 1980.

ROBERTO, S.R.; COUTINHO, A.; LIMA, J.E.O.; MIRANDA, V.S.; CARLOS, E.F. Transmissão de Xylella fastidiosa pelas cigarrinhas Dilobopterus costalimai, Acrogonia terminalis e Oncometopia facialis em citros. Fitopatologia Brasileira, v.21, p.517-518, 1996.

RODRIGUES, J.L.M.; SILVA-STENICO, M.E.; GOMES, J.E.; LOPES, J.R.S.; TSAI, S.M. Detection and diversity assessment of Xylella fastidiosa in field-collected and insect samples by using $16 \mathrm{~S}$ rRNA and $\operatorname{gyr} B$ sequences. Applied and Environmental Microbiology, v.69, p.4249-4255, 2003.

ROSSETTI, V.; De NEGRI, J.D. Clorose variegada dos Citros.- Revisão. Laranja, v.11, p.1-14, 1990.

ROUX, H.F.; BURDETTE, S.A.; ROUXBURGH, C.R. Produção de mudas de citros certificadas na África do Sul. In: SEMINÁRIO INTERNACIONAL DE CITROS TRATOS CULTURAIS, 5., Bebedouro, 1998. Bebedouro: Fundação Cargill, 1998. p.123-245.

SIEVERDING, E. Vesicular-arbuscular mycorrhiza management in tropical agrosystems. Eschborn: Federal Republic of Germany, Technical Corporation, 1991. 371p. 
SOUZA, M. Nutrição e adubação para produzir mudas de frutíferas. Informe Agropecuário, v.9, n.102, p.40-43, 1983.

SPOMER, L.A. The effect of container soil volume on plant growth. Hortscience, v.17, n.4, p.680-681, 1982.

SPURR, S.H.; BARNES, B.Y. Forest ecology. New York: Ronald Press, 1973. 571p.

TEDESCO, N.; CALDEIRA, M.V.W.; SCHUMACHER, M.V. Influência do vermicomposto na produção de mudas de caroba (Jacaranda micrantha Chamisso). Revista Árvore, v.23, n.1, p.1-8, 1999.

TINKER, P.B.H. Effects of vesicular-arbuscular mycorrizas on higher plants. Symposia the Society for Experimental Biology, v29, p.235-249, 1975.

TOLEDO, A.R.M. Efeito de substratos na formação de mudas de laranjeira (Citrus sinensis (L.) Osbeck cV.Pera Rio) em vaso. Lavras, 1992. 88p. Dissertação (Mestrado) - Escola Superior de Agricultura de Lavras.

TROCME, S.; GRAS, R. Suelo y fertilizacion en fruticultura. 2.ed. Madrid: MundiPrensa, 1979. 306p.

TUBELIS, A.; BERETTA, M.J.G.; RODRIGUES NETO, J. Primeira constatação de Clorose Variegada dos Citros (CVC) no Distrito Federal. Fitopatologia Brasileira, v.18, p.312, 1993. Suplemento.

TUKEY, J. Exploratory data analysis. New York: Addison-Wesley, 1977. 599p. 
VENABLES, W.N.; RIPLEY, B.D. Modern applied statistics with S-Plus. 4.ed. New York: Springer, 2002. I v.

VIEIRA, M.I. Minhocas dão lucros: reprodução, produção, instalações, comercialização. São Paulo: Prata,1993. 184p.

WHITTINGHAM, J.; READ, D.J. Vesicular-arbuscular mycorrhiza in natural vegetation systems. III Nutrient transfer between plants with mycorrhizal interconnections. New Phytologist, v.90, p.227-284, 1982.

WILCOX, H.E. Mycorrhizae. In: WAISEL, Y.; ESHEL, A.; KAFKAFI, U. (Ed.) Plant roots: the hidden half. New York: Marcel Dekker, 1991. p.731-765.

WILLIANSON, J.G.; CASTLE, W.S. A survey of Florida citrus nurseries. Proceedings of the Florida State Horticultural Society, v.102, p.78-82, 1989. 